\title{
Diagnostic Methods for the Comprehensive Health Assessment of the Long-Spined Sea Urchin, Diadema antillarum ${ }^{1}$
}

\author{
Ruth Francis-Floyd, Jan Landsberg, Roy Yanong, Yasu Kiryu, Shirley Baker, Deborah Pouder, \\ William Sharp, Gabriel Delgado, Nicole Stacy, Tom Waltzek, Heather Walden, Roxanna \\ Smolowitz, and Greg Beck²
}

\section{Background Information Importance of D. antillarum in Coral Reef Ecosystems}

The long-spined sea urchin, Diadema antillarum, has long been recognized as the keystone invertebrate herbivore maintaining habitat health on Caribbean coral reefs because they graze macroalgae that would normally outcompete and overgrow corals (Gardner et al. 2003; Furman and Heck 2009; Bodmer et al. 2015). However, a mass mortality event in the early 1980s decimated the $D$. antillarum population throughout the Caribbean (Lessios et al. 1984a; Lessios et al. 1984b), including the Florida Keys (Forcucci 1994). Prior to the 1983-1984 mortality event, Diadema densities exceeded 20 individuals $/ \mathrm{m}^{2}$ in some locations in the Caribbean (Lessios 1988; Chiappone et al. 2002). Populations in the Florida Keys were lower, averaging densities of 4-5 individuals $/ \mathrm{m}^{2}$ (Chiappone et al. 2002). Since that mortality event, the $D$. antillarum populations in the Florida Keys have not recovered (Kissling et al. 2014). There was a slight recovery in the late 1980 s, up to a density of $0.3-0.58$ individuals $/ \mathrm{m}^{2}$; however, this declined to fewer than 0.01 individuals $/ \mathrm{m}^{2}$ following a second mortality in 1991 (Forcucci 1994). Recovery of Diadema populations throughout the Caribbean has been inconsistent and modest (Lessios 2015).

Coral reef degradation is attributable to several factors, including disease, overfishing, climate change, eutrophication, poor water quality, and the loss of urchins (Hughes et al. 1987). Furthermore, the loss of live coral cover has resulted in a flattening of the physical structure of the reef (Jackson 2008). This loss of structural or habitat complexity means that the coral reef ecosystem is no longer healthy and cannot maintain the species diversity and high abundance of associated fish and invertebrates, some of which are commercially and recreationally important. Rogers and Lorenzen (2016) have demonstrated that structurally

1. This document is VM244, one of a series of the Veterinary Medicine-Large Animal Clinical Sciences Department, UF/IFAS Extension. Original publication date May 2020. Visit the EDIS website at https://edis.ifas.ufl.edu for the currently supported version of this publication.

2. Ruth Francis-Floyd, professor, Extension veterinarian, UF College of Veterinary Medicine and UF/IFAS School of Forest Resources and Conservation; Jan Landsberg, research scientist, Florida Fish and Wildlife Conservation Commission; Roy Yanong, professor and Extension veterinarian, Program in Fisheries and Aquatic Sciences, UF/IFAS School of Forest Resources and Conservation, UF/IFAS Tropical Aquaculture Laboratory; Yasu Kiryu, contributor, Florida Fish and Wildlife Conservation Commission; Shirley Baker, associate professor, molluscan biology \& aquaculture, Program in Fisheries and Aquatic Sciences, UF/IFAS School of Forest Resources and Conservation; Deborah Pouder, coordinator of research programs and services, diagnostic lab manager, UF/IFAS Tropical Aquaculture Laboratory, UF/IFAS School of Forest Resources and Conservation, Program in Fisheries and Aquatic Sciences; William Sharp, contributor, Florida Fish and Wildlife Conservation Commission; Gabriel Delgado, contributor, Florida Fish and Wildlife Conservation Commission; Nicole Stacy, clinical assistant professor, Department of Comparative, Diagnostic, and Population Medicine, UF College of Veterinary Medicine; Tom Waltzek, associate professor, Department of Infectious Diseases and Immunology, UF College of Veterinary Medicine; Heather Walden, research assistant professor, Infectious Diseases and Pathology, UF College of Veterinary Medicine; Roxanna Smolowitz, contributor, Roger Williams University; and Greg Beck, contributor, University of Massachusetts, Boston; UF/IFAS Extension, Gainesville, FL 32611.

The Institute of Food and Agricultural Sciences (IFAS) is an Equal Opportunity Institution authorized to provide research, educational information and other services

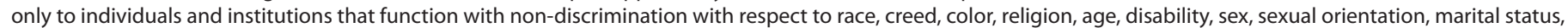

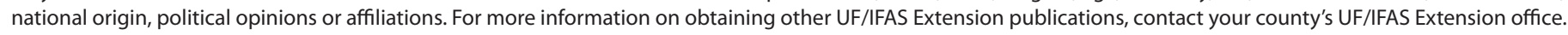
U.S. Department of Agriculture, UF/IFAS Extension Service, University of Florida, IFAS, Florida A \& M University Cooperative Extension Program, and Boards of County Commissioners Cooperating. Nick T. Place, dean for UF/IFAS Extension. 
complex environments are important for recovering populations of $D$. antillarum in Curacao. Moreover, macroalgal overgrowth due to lack of urchin grazing has led to reduced recruitment of coral larvae and growth of juveniles, exacerbating the problem of coral reef degradation. Urchins maintain healthy ecosystems as grazers and act as a food source for a variety of fish and invertebrate predators. Because of urchins' key role in coral reef ecosystems, natural resource managers have had great interest in reestablishing a functional population of $D$. antillarum in the Florida Keys as part of a holistic coral reef restoration effort (Sharp et al. 2018).

\section{Current Status of D. antillarum in the Florida Keys}

In the decades since the mass mortality event, D. antillarum populations have yet to recover to historical levels (Lessios 2016). In the Florida Keys, the density of $D$. antillarum has remained nearly two orders of magnitude lower than that estimated before the event (Kissling et al. 2014). The reasons for the lack of recovery remain poorly understood. However, it has been speculated that D. antillarum remain so sparsely distributed that the reproductive success is only a fraction of pre-mortality event levels, resulting in few individuals recruiting to the depleted population (Feehan et al. 2016). Another factor contributing to the lack of $D$. antillarum recovery is the low survival rate of new recruits. The coral reefs in the Florida Keys, like those elsewhere in the Caribbean region, have become highly degraded and now provide much less shelter for D. antillarum. Consequently, urchins may be subjected to much higher predation rates (Sharp et al. 2018; Rogers and Lorenzen 2016; Dame 2008).

The lack of recovery of the D. antillarum population in the Florida Keys and the effect this has had on the continued degradation of its coral reef ecosystem are of great concern to Florida's resource managers. Managers have prioritized the development and evaluation of procedures necessary to reestablish an ecologically functional population of $D$. antillarum as part of a large-scale coral reef ecosystem restoration effort (see Florida's State Wildlife Action Plan at http://myfwc.com/media/2652518/CoralReef.pdf). Efforts initially focused on developing the procedures to captive-spawn and rear D. antillarum to augment the wild population. However, the State of Florida's stock enhancement and stock restoration policy requires a thorough understanding of the genetic structure and the health characteristics of organisms produced ex situ relative to those of the wild population before the organisms may be released into the wild, even on an experimental scale (Florida Fish and Wildlife Conservation Commission Rule
68B-8.003, Florida Administrative Code). Accordingly, in 2014, an effort was initiated to develop methods and identify criteria to assess the health of hatchery-propagated D. antillarum and produce a standardized protocol from which the FWC can develop a health certification policy. This will allow hatchery-propagated $D$. antillarum to be released into the wild. It will also be useful for the health assessment and identification of the "normal flora" of wild D. antillarum in Florida waters.

\section{D. antillarum Mortality Events}

From 1983-1984, there was a massive die-off of $D$. antillarum throughout its western range, covering an area of approximately 3.5 million $\mathrm{km}^{2}$ that included the Caribbean, south Florida, and Bermuda (Lessios et al. 1984a). This loss of $D$. antillarum remains one of the most widespread invertebrate mortality events ever recorded. Over a 13-month period, more than $93 \%$ of the population died (Lessios et al. 1983, 1984a, 1984b; Bak et al. 1984; Murillo-Castro and Cortés-Núñez 1984; Hughes et al. 1985; Hunte et al. 1986; Lessios 1988). The mortality event was species-specific and seemed to follow the flow of currents in the western Caribbean from the initial outbreak location near the eastern entrance of the Panama Canal. From there, the mortality event spread to Jamaica and northward into the Gulf of Mexico and ultimately southward through the Florida Straits to the Florida Keys, the Gulfstream, and finally Bermuda (Figure 1). Phinney et al. (2001) believe these observations are consistent with the hypothesis that local currents may have spread a waterborne pathogen. They argue, however, that movement of local currents would not explain concurrent mortality in the eastern Caribbean. Phinney et al. (2001) suggest that remote sensing data would support a second hypothesis that ballast water could have moved a pathogen from an infected area to a "clean" area. They conclude that both mechanisms may have contributed to the rapid spread of the suspect agent during this event.

Affected urchins had an accumulation of mucus and detritus on the spines; broken or lost spines leading to tubercle exposure; dermal lesions on the test and peristome; and progressive exposure of the skeleton with necrosis of remaining tissue, followed by urchin mortality usually occurring within four days (Bak et al. 1984; Jangoux 1990). The most affected sea urchins were those with a test diameter of 20-40 mm (Hunte et al. 1986). Descriptions of the event were consistent with movement of a virulent waterborne pathogen throughout the affected area (Lessios et al. 1984b), but a causative agent was never identified. 


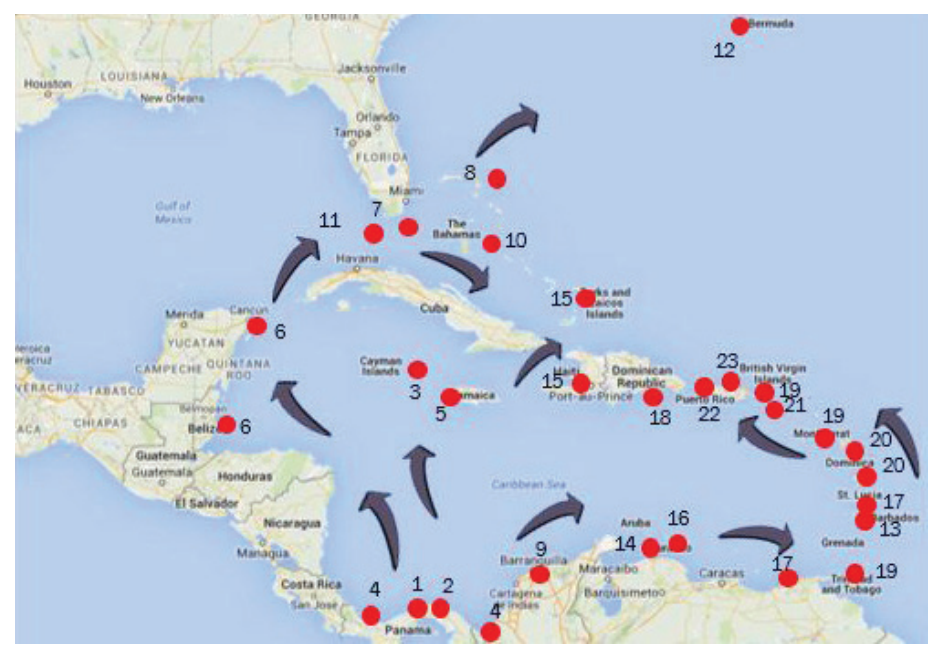

Figure 1. Spread of Diadema antillarum mortality in the Caribbean and mid-west Atlantic (January 1983-February 1984). (Adapted from Lessios et al. 1984b)

Bauer and Agerter (1987) isolated two Clostridium spp. from dying $D$. antillarum in an aquarium receiving water from Biscayne Bay, Florida, in September of 1983. However, these organisms were not detected in wild animals. Seven years after the 1983-1984 event, a second epizootic was reported in the Florida Keys. Further study (Bauer and Agerter 1994) indicated that gram-positive bacteria such as Clostridium could be a potentially significant pathogen.

The loss of Diadema antillarum from the Caribbean basin and Florida Keys contributed to major ecosystem changes, such as phase shifts with significant declines in corals and increases in macroalgae and filamentous algae with concomitant alterations in the benthic and reef biota (de Ruyter Van Steveninck and Bak 1986; Liddell and Ohlhorst 1986; de Ruyter van Steveninck and Breeman 1987; Hughes et al. 1987; Carpenter 1988, 1990a, 1990b; Levitan 1988;

Knowlton 2001, McManus and Polsenberg 2004; Mumby et al. 2006; Feehan and Scheibling 2014). To this day, recovery has been slow to moderate in most areas, and D. antillarum population numbers are still low compared to their premortality levels (Lessios 1995; Miller et al. 2003; Lessios 2005; Weil et al. 2005; Williams et al. 2010; Beck et al. 2014). Florida, in particular, has had poor recovery (Figure 2) (Chiappone et al. 2002, 2008).

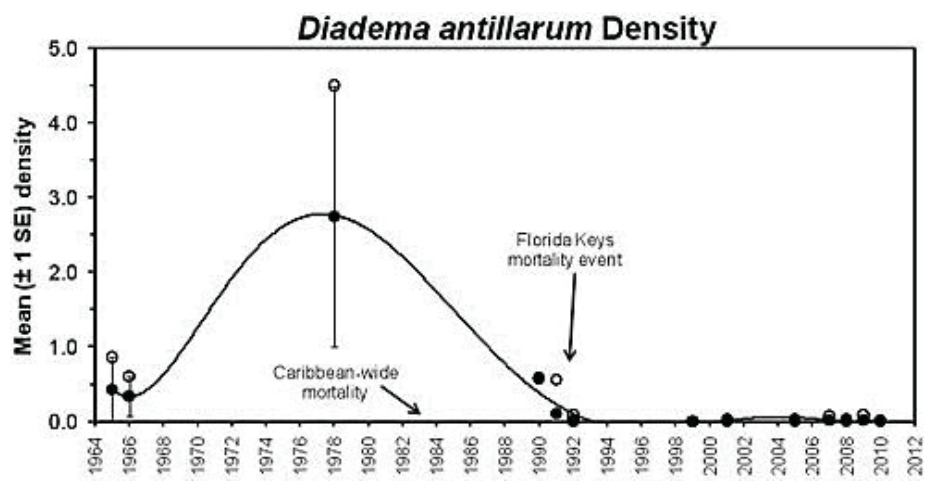

Figure 2. Temporal patterns in mean Diadema antillarum density on shallow spur and groove reefs in the Florida Keys. (Reproduced from NOAA/FKNMS 2015)

\section{Recognized Parasites and Diseases of Sea Urchins}

In general, echinoids have experienced sporadic mass mortality events, usually on a local scale, and these are sometimes associated with their "boom and bust" cycles (Pearse et al. 1977; Boudouresque et al. 1980; Miller and Colodey 1983; Williams et al. 1986, 1996; Nagelkerken et al. 1999; Uthicke et al. 2009; Hendler 2013; Jurgens et al. 2015). In some cases, the die-offs were attributable to changing or suboptimal environmental conditions (Scheibling and Stephenson 1984; Scheibling and Hennigar 1997; Lester et al. 2007; Scheibling et al. 2010; Girard et al. 2012; Hendler 2013) or to primary pathogens (Jones et al. 1985; Jones and Scheibling 1985; Feehan et al. 2013), or to a combination of the two (Dumont et al. 2004; Buchwald et al. 2015). Disease outbreaks and mass mortalities amongst wild echinoids appear to have increased in the last few decades (Ward and Lafferty 2004; Feehan and Scheibling 2014) with notable mortalities of other Diadema species also being reported (Benítez-Villalobos et al. 2009; Dykova et al. 2011; Clemente et al. 2014).

Clinical disease in sea urchins is poorly understood. Jangoux $(1984,1990)$ provided detailed reviews of disease in echinoderms and published a series of review articles in 1987 (Jangoux 1987a, b, c, d) describing suspect pathogens and opportunists that have been associated with abnormalities in various species of echinoderms. Several "syndromes" such as "bald sea urchin disease," "spotting," and "black mouth" provide descriptive designations of observed lesions in wild and cultured urchins (Wang et al. 2013b). Some bacteria have been isolated from diseased urchins, but specific etiologic associations between the presence of suspect pathogens and development of lesions are not always consistent (Harms 2006; Wang et al. 2013b). As the culture of sea urchin species continues to grow, there is little doubt that our understanding of disease processes in captive animals will improve. Abrasions can 
be initiated by mechanical damage, parasites, or predators. Lesions may allow for secondary bacterial infection and a range of external lesions including loss of spines, tube feet, and pedicellariae. Examples of nonspecific opportunistic bacteria that have been isolated from sea urchins include Acinetobacter, Aeromonas, Alcaligenes, Bacillus, Exiguobacterium, Flavobacterium, Flexibacter, Pseudoalteromonas, Pseudomonas, Tenacibaculum, and Vibrio (Maes and Jangoux 1984; Gilles and Pearse 1986; Jangoux 1987; Roberts-Regan et al. 1988; Tajima et al. 1997a, 1997b, 1998; Takeuchi et al. 1999; Bauer and Young 2000; Li and Xu 2000; Tajima and Lawrence 2001; Sogabe et al. 2002; Taniuchi et al. 2002; Masuda et al. 2004; Becker et al. 2007; Tajima et al. 2007; Becker et al. 2008; Wang et al. 2013a, 2013b).

Under adverse conditions, Diadema can be parasitized by symbionts or commensals that usually cause little harm to their hosts. Several such gastrointestinal parasites have been documented, particularly ciliates and amoeba (Biggar and Wenrich 1932; Urdaneta-Morales and De McLure 1966; Jones and Rogers 1968; Groliere et al. 1980; Jangoux 1987). Parasitic pathogens include Paramoeba (Jellett et al. 1989; Dykova et al. 2011; Feehan et al. 2013), although it is unclear if these amoebae are primary etiologic agents or if they act synergistically with bacteria to cause spine loss, epidermal exfoliation, and test lesions (Dykova et al. 2011).

A range of helminth parasites has been documented in urchins, usually causing little pathology other than a localized cellular host response (Jangoux 1984; Shimizu 1994; Tajima and Lawrence 2001). One exception is the nematode Echinomermella matsi, which causes gonadal infections and parasitic castration in Strongylocentrotus droebachiensis with significant effects on population survival (Hagen 1987, 1992; Skadsheim et al. 1995; Hagen 1996; Sivertsen 1996; Stien et al. 1998; Stien 1999).

\section{Diagnostic Methods}

Diagnostic methods were developed for Diadema antillarum with the intent of improving our understanding of normal behavior and flora, a prerequisite to appreciating disease processes in this species. These methods will be used to detect pathogens in sick animals and will be important for health certification of cultured urchins that may be released into Florida waters as part of the state's coral reef restoration efforts.

For purposes of health certification, behavioral characteristics were described and divided into Category One and Category Two behaviors. Category One behaviors are defined as 1) attachment to substrate and 2) assessment of spine position. The authors suggest that all animals cleared for release must demonstrate normal behavior for both important characteristics. Descriptions of each are provided below.

Category Two behaviors are defined as 1) defecation; 2) righting response; 3 ) touch and defense responses; 4) light response; and 5) observed tube feet activity. Each of these is described below. For a batch of live urchins to be cleared for release to Florida waters, the Diadema health assessment team suggests that $20 \%$ of the animals be examined for Category Two behavioral responses. Healthy animals are expected to complete at least three of these five behaviors.

Assessment of appearance is also recommended for the $20 \%$ of a batch of urchins under consideration for release that are subjected to the Category Two Behavioral Assessment (described below). This is considered part of the physical examination process for the species. This more detailed examination should include an assessment of color and appearance, consideration of the spines and test, as well as collection of morphometric data. In addition to a gross physical examination, examination with a dissecting scope or head loop is recommended for detection of small lesions of the test, areas of focal spine loss, external flora (i.e., amphipods), and movement of tube feet and pedicellariae.

Ancillary diagnostic tests for more detailed evaluations, including necropsy, may include collection of coelomic fluid for microbial testing, cytology, or immune function tests. Examination of fresh material under a microscope can include various internal and external tissues as well as fecal material. This manual also describes preservation of tissues for histologic processing or parasite identification. Archiving tissues in RNAlater ${ }^{\circledR}$ and freezing fresh material in a $-80^{\circ} \mathrm{F}$ freezer are recommended whenever possible.

\section{Use of Diagnostic Forms}

In an effort to standardize an approach to diagnostic evaluation of the species, three reporting forms have been developed for laboratory and diagnostic work with $D$. antillarum. Each is provided as a PD at the end of this manual for investigators.

i. Field Collection Form. The Field Collection Form (Appendix 1) was developed to facilitate collection of data about the origin (source) of organisms as well as behavior and physical condition prior to handling. For wildcaught organisms, location (preferably GPS coordinates) and information on substrate, depth, water temperature, 
and conditions are included. For cultured animals, the source should include the name and address of the farm as well as information on the tanks or systems from which the animals were taken. Behavioral information collected prior to handling should include shelter status, position of their spines, body position, and attachment to substrate.

\section{ii. Health Evaluation-Initial In-Lab Assessment. The} In-Lab Assessment (Appendix 2) is the primary necropsy form and includes a step-by-step examination that begins with the behavioral assessment. The behavioral assessment is followed by the assessment of appearance, physical examination, and collection of morphometric data. More detailed diagnostic testing can then be conducted as appropriate.

iii. Health Evaluation-Follow-Up Lab Assessment. The Follow-Up Lab Assessment (Appendix 3) provides a means of tracking samples which may have been sent to different labs for analyses. It provides a single document to summarize lab results for a single animal or case.

\section{Handling Diadema}

Diadema antillarum is a delicate animal, but it is covered with long and very sharp spines. To minimize injury to both the animal and personnel, tongs can be used to facilitate handling (Figures 3 and 4). The animal should be handled in the water, whenever possible, to minimize injury.

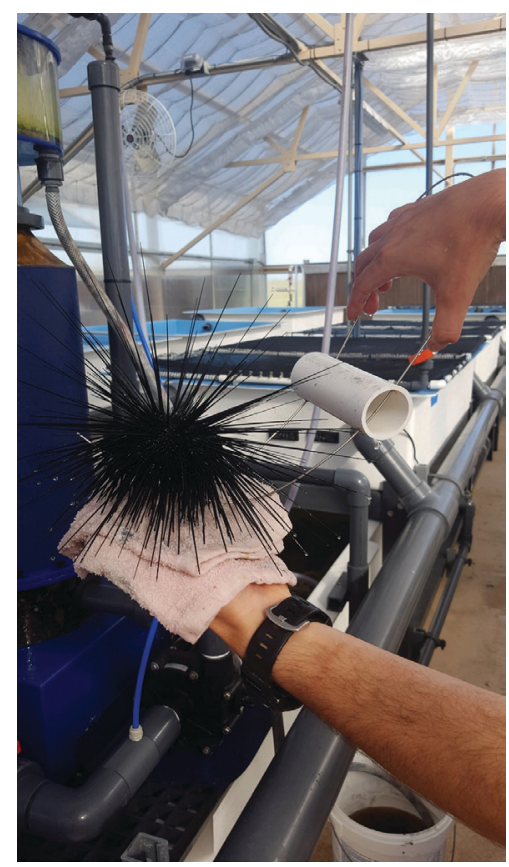

Figure 3. Use of tongs to safely handle adult D. antillarum. The tongs protect the animal while minimizing the chance of the handler being stuck by its very sharp spines.

Credits: J. Patterson, UF/IFAS

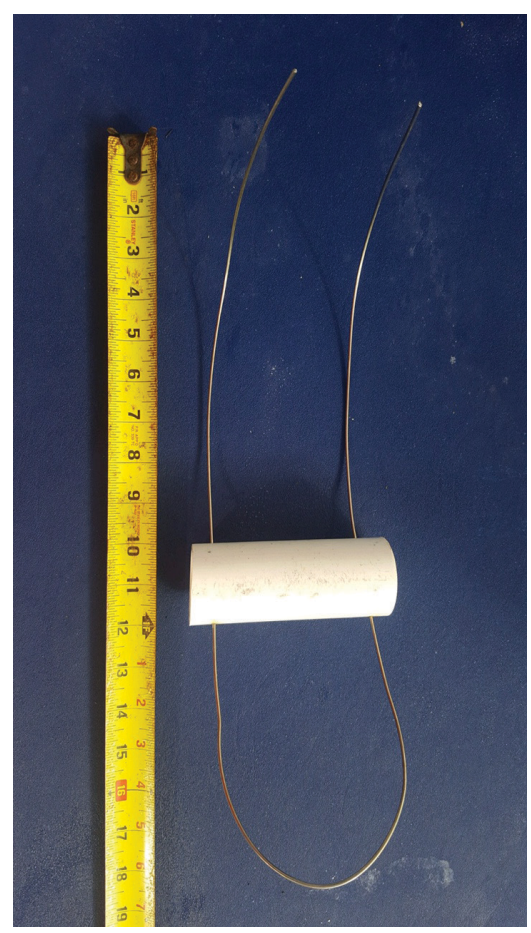

Figure 4. Tongs used to handle $D$. antillarum can be handmade using coat hanger wire or wire a little stiffer than that. A piece of two-inch PVC pipe can be used to create a handle, provide support, and stiffen the wire.

Credits: J. Patterson, UF/IFAS

\section{Sedation}

Methane tricaine sulfonate (MS-222) has been used to sedate sea urchins, which can facilitate handling in some circumstances. Applegate et al. (2016) evaluated use of buffered MS-222 to sedate or anesthetize the purple-spined sea urchin (Arbacia punctulata) using concentrations of 400 and $800 \mathrm{mg} / \mathrm{L}$, respectively. Both concentrations tested were safe, effective, and resulted in rapid release of treated urchins from substrate, followed by loss of righting reflex and poor spine position. Subsequently, Martony et al. (2018) used buffered MS-222 (400 mg/L) to sedate Diadema antillarum for diagnostic imaging. The use of the anesthetic facilitated handling and was effective. Animals were euthanized at the end of the study, and target animal safety was not assessed.

\section{Behavioral Assessment}

A behavioral profile for D. antillarum was developed to facilitate health assessment. Applegate et al. (2016) described similar behavioral parameters as a means of evaluating the level of sedation and anesthesia in purplespined sea urchins treated with MS-222. For purposes of health certification (Appendix 4), behavioral traits are divided into two groups. Category One behaviors are traits that should be observed in all healthy urchins under consideration for release to Florida waters. There are only 
two of these: attachment to substrate and position of spines. Both are described below. Five additional behaviors are designated as Category Two behaviors. The Diadema health assessment team recommends that a subset consisting of $20 \%$ of urchins under consideration for release should demonstrate at least three of these when examined. Descriptions of all traits, including techniques and photographs, are provided below. An animal with a normal behavioral profile may be a candidate for release following a nonlethal examination. Animals that are considered behaviorally abnormal must receive more evaluation. This may not mean that they are ill.

\section{Category One Behaviors}

Two behavioral traits are designated as Category One behaviors. The Diadema health assessment team recommends that any urchin considered for release must be designated "normal" for both of these. Each of these is described below.

1. Attachment to substrate is noted when removing the animal from a housing unit. A healthy urchin should be firmly attached to the substrate.

\section{Attachment to Substrate}

Heathy urchins should be difficult to detach from the substrate. Ideally, the urchins should be sheltered, if cover is available to them (Figures 5 and 6). This information can be requested from divers who collect wild animals (Figure 6, see Site Collection Form, Appendix 1). Realistically, however, divers working under marginal (weather) conditions may not be able to provide this information. Instead, it can be part of the lab assessment. Urchins may be held in a wet lab for hours to days before their examination. It should take some effort to dislodge them from the side or bottom of holding tanks. Urchins that are floating or unattached on the bottom of a tank would be considered moribund (Figure 7).

2.Spine position (see below) should be assessed while the animal is still in the holding area, and at initiation of the physical examination. A healthy urchin should have erect and extended spines. Drooping spines may be indicative of disease.

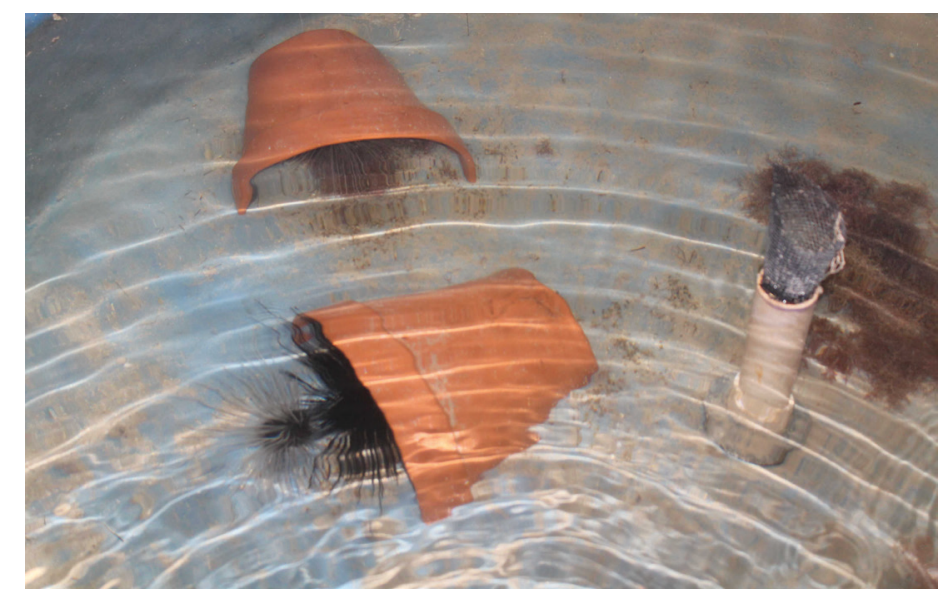

Figure 5. Diadema antillarum held in flow-through tanks at the FWRI research laboratory in Marathon, FL. These animals were firmly attached to the substrate and actively sought shelter. This is normal behavior.

Credits: R. Francis-Floyd, UF/IFAS

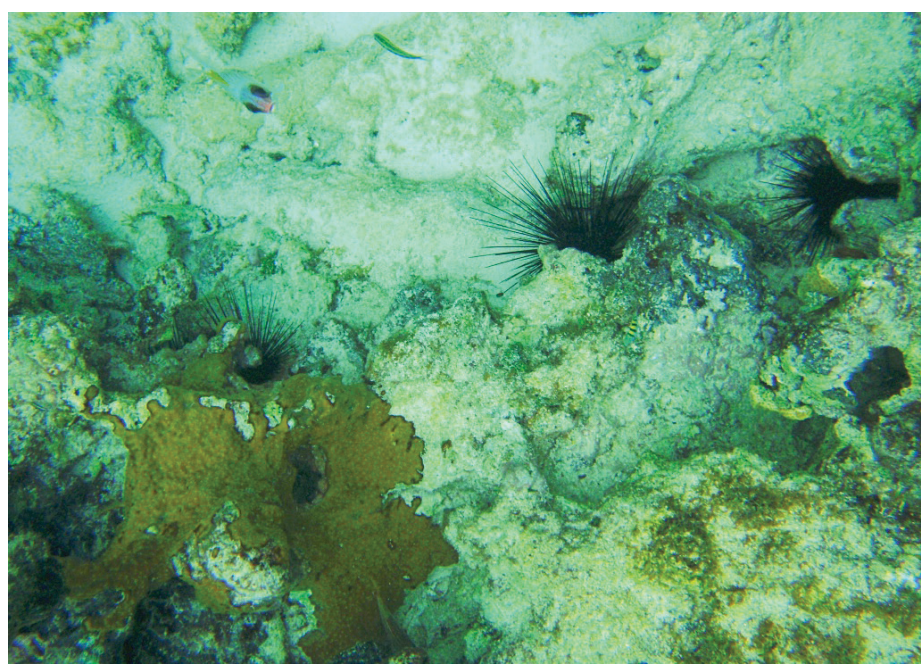

Figure 6. Wild Diadema antillarum sheltering on a reef near Cozumel, Mexico.

Credits: B. Stevens, California Science Center Foundation

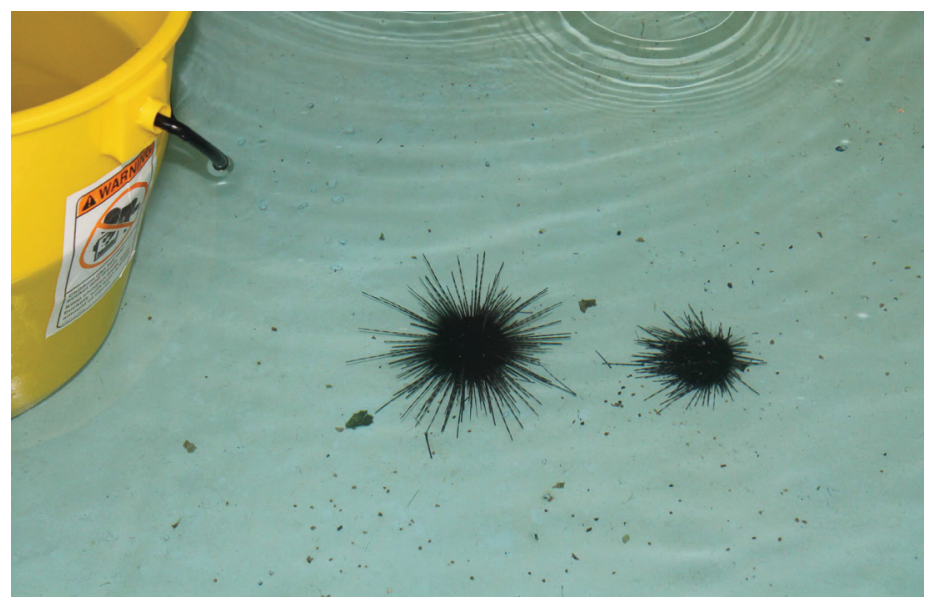

Figure 7. A healthy urchin is shown on the left. Spines are erect, and the animal is firmly attached to the substrate. A moribund animal, or one that has just died, is shown on the right. Spines are flat on the bottom of the tank. It begins to float just off the bottom as it detaches from the substrate.

Credits: R. Francis-Floyd, UF/IFAS 


\section{Spine Position}

Spine position on a normal $D$. antillarum should be erect. If challenged, the animal may bring several spines together to form a spear-like structure (see touch and defense responses below). A moribund animal will not have erect spines. Instead, the spines will lay flat. We believe this is characteristic of a moribund (or dead) urchin.

\section{Category Two Behaviors}

In addition to attachment to substrate and spine position, five additional behaviors are part of a suite of normal behavioral responses for $D$. antillarum. A recommendation has been made that a clinically normal urchin would demonstrate at least three of the five Category Two behaviors (described below) during a routine examination. Any urchin that does not meet these criteria would need to receive further examination and would not be cleared for immediate release. The Diadema health assessment team recommends that at least $20 \%$ of urchins in a population, or batch, under consideration for release be tested for Category Two behavioral competence.

\section{Defecation}

1. Defecation is noted when the urchin is first handled. A healthy urchin should have a full gut, so a recently collected animal would be expected to defecate when manually examined.

Diadema antillarum are herbivores. A healthy urchin should have a full gut due to active grazing activity. Subsequent work with captive D. antillarum has demonstrated that urchins in an aquarium or tank that do not feed for several days may have decreased fecal output (Violetta et al. 2017). This observation may be important when using fecal output as a measure of health in captive organisms. A healthy urchin with access to food should produce abundant fecal material when the animal is handled.

\section{Righting Response}

2. Righting response is defined as the urchin's ability to correct its orientation when placed upside-down. This behavior is best observed when handling an urchin that is still in the water but has been detached from the substrate. Using tongs, the animal can be inverted while fully submerged. It should attempt to right itself and resettle to the bottom of the tank in an upright orientation (Figure 8).

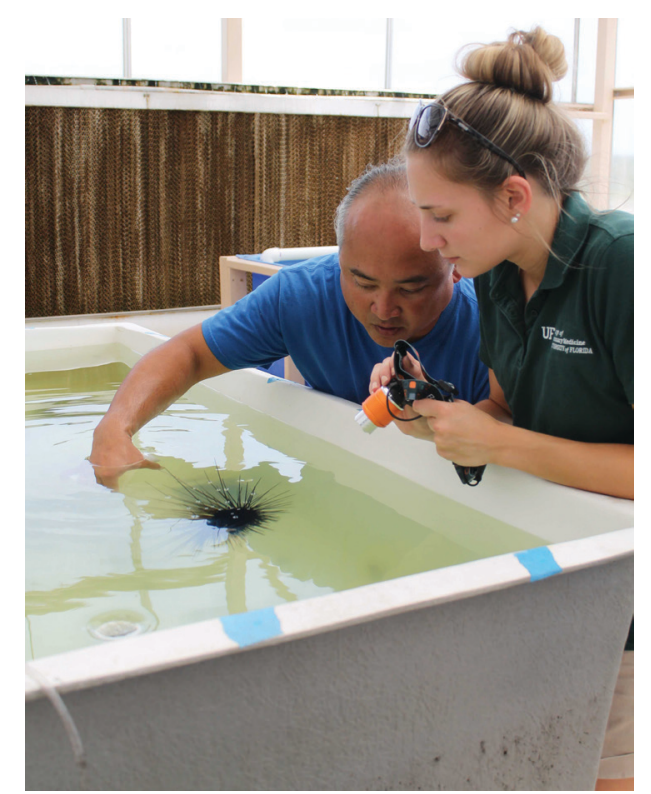

Figure 8. A healthy urchin will try to right itself when placed upsidedown. This is safest when the animal is fully submerged and allowed to settle back to the bottom of its tank following manipulation. Credits: R. Francis-Floyd, UF/IFAS

\section{Touch and Defense Responses}

3. Touch and defense responses are similar and interrelated, so they are presented together.

A touch response is defined as the urchin's response to touch. A healthy urchin should attempt to move away from the source of the touch, or it may raise its spines towards the perceived threat.

A defense response is tested by threatening the urchin with a probe or putting pressure on the test with a long pair of forceps (Figure 9). A healthy urchin should form

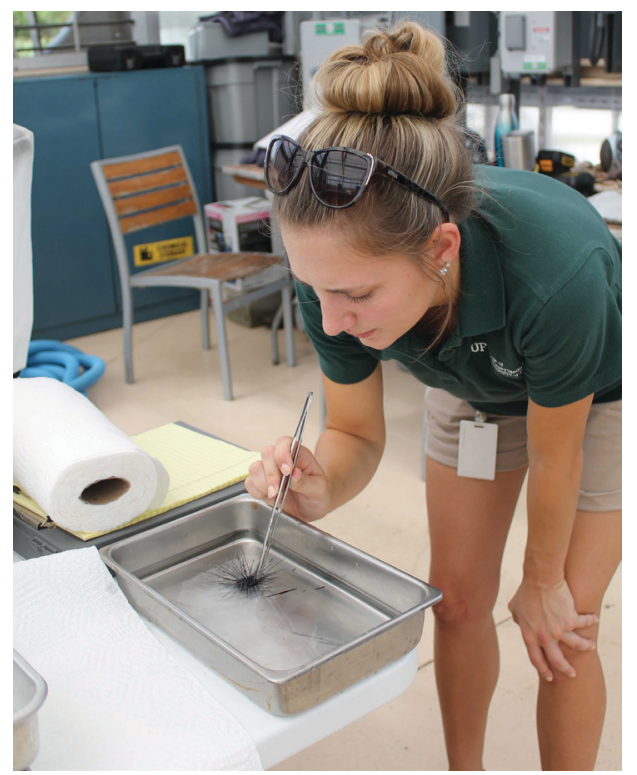

Figure 9. Assessing the touch response as part of the behavioral assessment of $D$. antillarum.

Credits: R. Francis-Floyd, UF/IFAS 
a multi-spear-like defense structure by pulling its spines together and pointing them in the direction of the threat.

\section{Light Response}

4. Light response is defined as the urchin's behavioral response to light. A healthy urchin should attempt to move under shelter (i.e., away from a light source), as demonstrated in Figure 10.

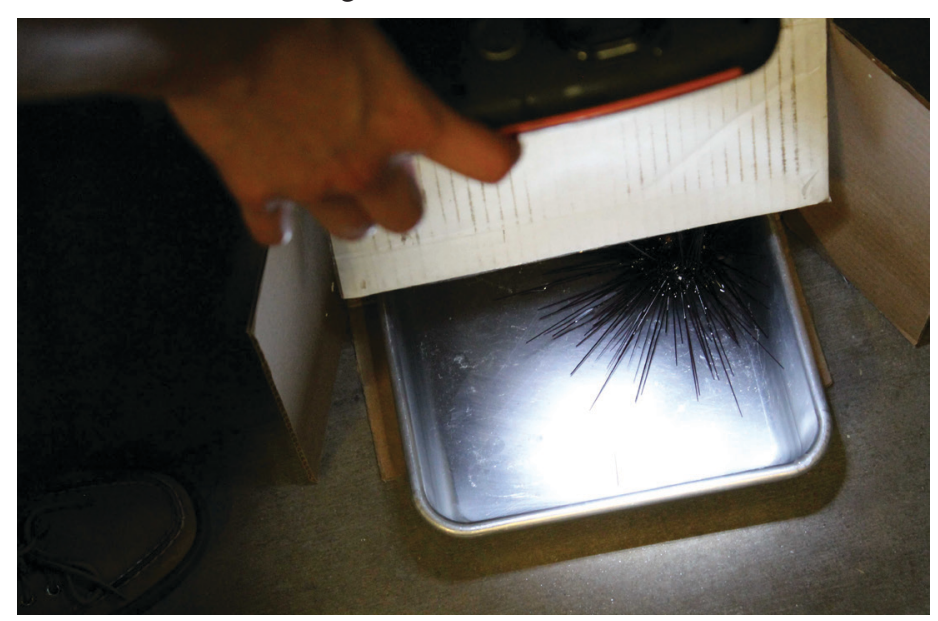

Figure 10. An urchin tries to seek shelter by moving into a dark box placed over its holding area. To increase the differentiation of light and dark areas, a bright light is pointed towards the urchin on the outside of the darkened space. A healthy urchin would move quickly into the dark, covered area.

Credits: R. Francis-Floyd, UF/IFAS

In a captive setting, maximizing contrast between light and dark areas is helpful in eliciting this response. Darkening half of the pan or small tank while brightly illuminating the other half will enhance this behavioral response. Healthy urchins will readily move into the darkened half of the tank (Figures 5 and 6). A healthy urchin should show a tendency to seek shelter or dark areas.

\section{Tube Feet Activity}

5. Tube feet activity evaluates the movement of tube feet when the urchin is handled. A healthy urchin should have active tube feet, and this activity may increase during handling, indicating an active escape response.

Tube feet and pedicellariae are also examined as part of the external examination conducted with the dissecting scope or head loop. Nevertheless, tube feet activity should be evident prior to the more detailed external exam (Figure 11), but confirmed during that process.

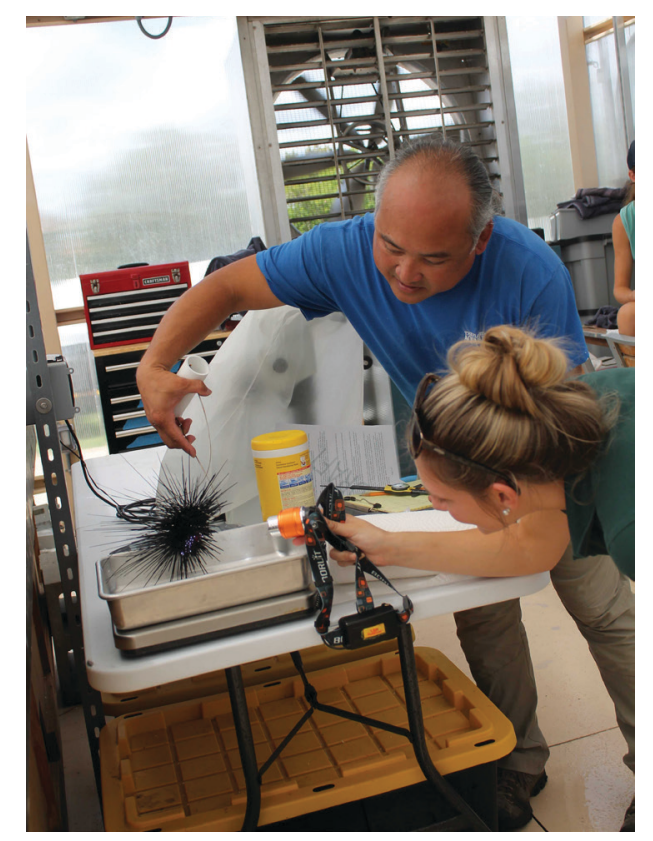

Figure 11. Examining the ventral surface of Diadema antillarum for tube feet activity. This can also be done with the animal fully submerged.

Credits: R. Francis-Floyd, UF/IFAS

\section{Gross Appearance and Physical Examination}

Once the behavioral assessment has been completed, a physical examination should be conducted. The first step in the physical examination process is assessment of color and appearance, with particular attention paid to the condition of the spines and test. Morphometric data should be collected prior to completion of the physical examination.

\section{Color and Appearance}

Diadema antillarum collected in the Florida Keys in 2015 were found in a variety of colors. These included black, purple, white, gray, and parti-colored animals. The parti-colored organisms were typically black and white (Figure 12). Color variation could be subtle or could be approximately $50 \%$ of each color.

Juvenile animals are reported to have horizontal stripes across their spines (Figure 13).

Assessment of broken or missing spines is an important part of the health assessment examination. On a normal animal, spines should be intact, not broken or missing. Handling animals carefully (i.e., using tongs) is important to prevent accidental damage to the delicate spines. Handling animals in water also helps minimize external injury and damage to spines. 


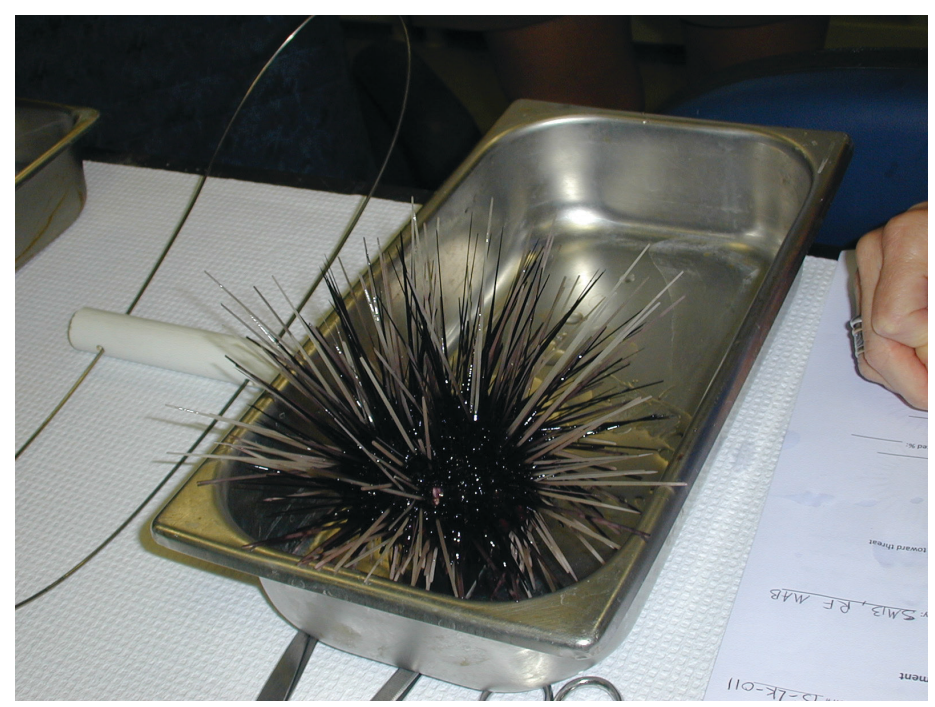

Figure 12. An example of a black-and-white, parti-colored $D$. antillarum. This animal had about $50 \%$ white spines and $50 \%$ black spines.

Credit: R. Francis-Floyd, UF/IFAS

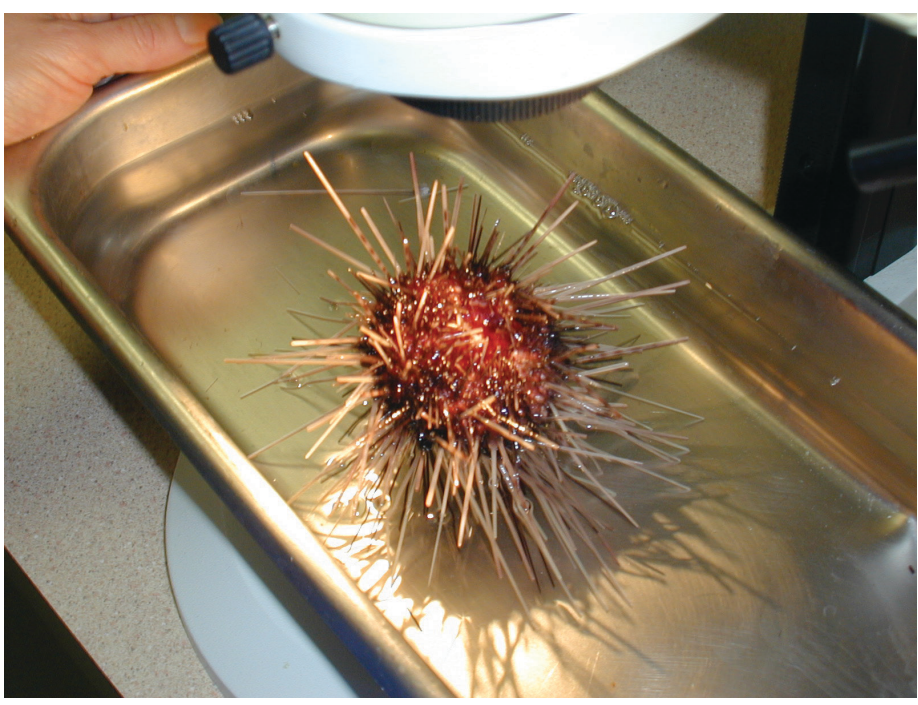

Figure 13. Horizontal stripes on spines of a small sea urchin. This observation is supposed to be definitive of a juvenile animal. Our observations suggest that some animals with striped spines have what appear to be mature gonads.

Credit: R. Francis-Floyd, UF/IFAS

The Diadema health assessment team has recommended the following for an urchin to be considered normal and healthy:

- No more than $5 \%$ of the spines broken or missing

- No lesions are observed on the test (methods for external examination of Diadema are described below). Specifically, they must have:

- Less than $5 \%$ of the test exposed (bare area)

- No sores or discolored areas (in relation to the rest of the test)
- No grossly visible attached organisms

- No abnormal growths (altered morphology of tissue and test)

\section{Morphometrics}

Morphometric measurements consist of urchin weight as well as test diameter and height (Figures 14 and 15).

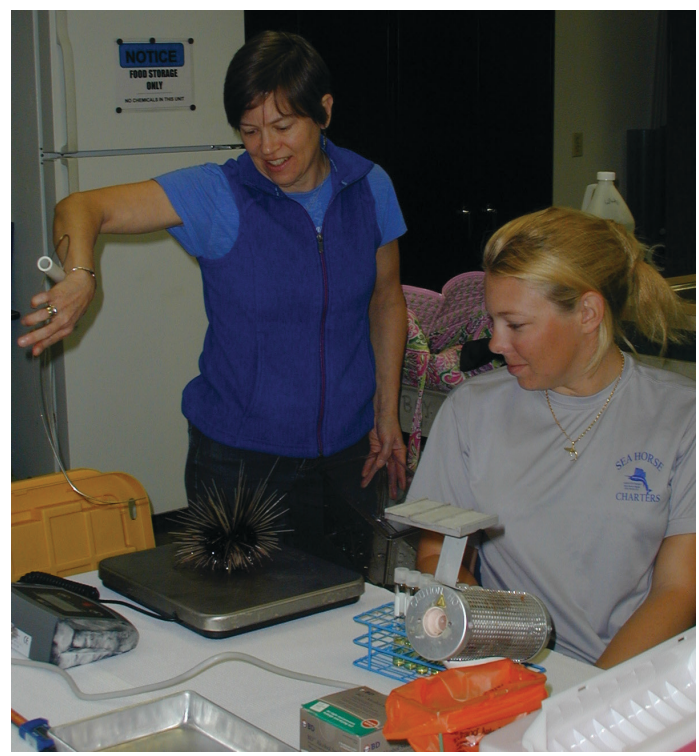

Figure 14. Weighing D. antillarum as part of the physical examination process.

Credit: R. Francis-Floyd, UF/IFAS

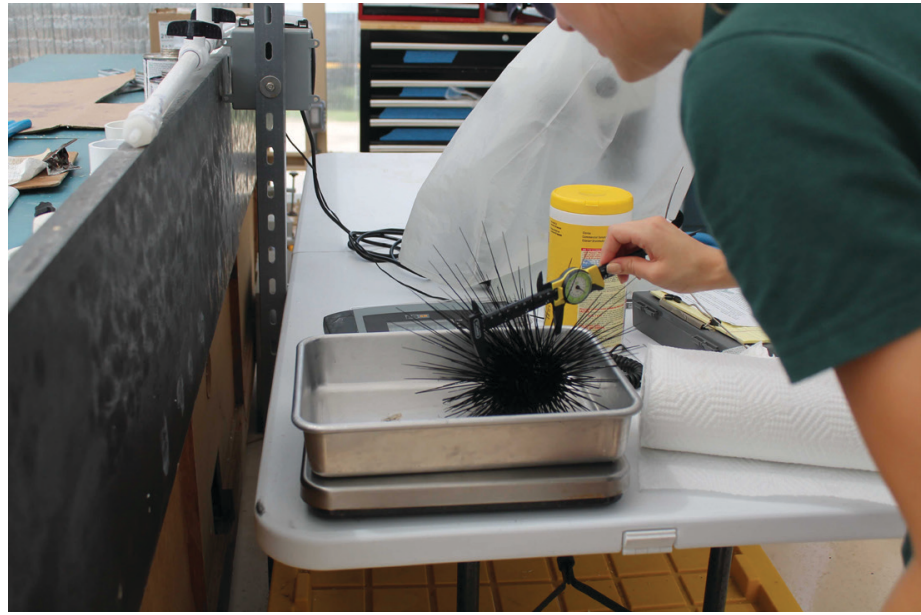

Figure 15. Measuring test diameter in D. antillarum. Calipers with extra-long "arms" make the job safer for animals and handlers. Animals should be kept submerged whenever possible. Credit: R. Francis-Floyd, UF/IFAS

If the examination is to be nonlethal, then the diagnostician should try to measure the test diameter and height by placing the calipers between the spines. It is very important not to damage the spines or to be stuck by them.

If the urchin is to be necropsied, the spines can be cut off, as shown in Figure 16. Although echinoderms are not covered by the Animal Welfare Act, sedation with MS-222 
prior to cutting spines and euthanizing the animal may be considered. Removing the spines makes it easier to use calipers to measure the test. Note that protective eyewear should be worn if spines are to be removed. Our investigators found that cutting the spines while the animal was submerged in a small tank worked well because the spines stayed under the water, decreasing the chance of human injury.

\section{External Examination}

Detection of external lesions requires close examination. Use of a dissecting microscope to examine the live animal is strongly recommended (Figure 16). Evaluation should include presence or absence of lesions (areas of spine loss, test erosion, or ulceration), any damage that would result in the loss of test structural integrity, the presence or absence of macroscopic flora (i.e., isopods, amphipods, or any epibionts), and movement or activity of tube feet and pedicellariae. If a dissecting scope is not available, or the animal is too large to be safely manipulated in such a restricted area, a magnifying head loop or other magnification device may be an acceptable alternative.

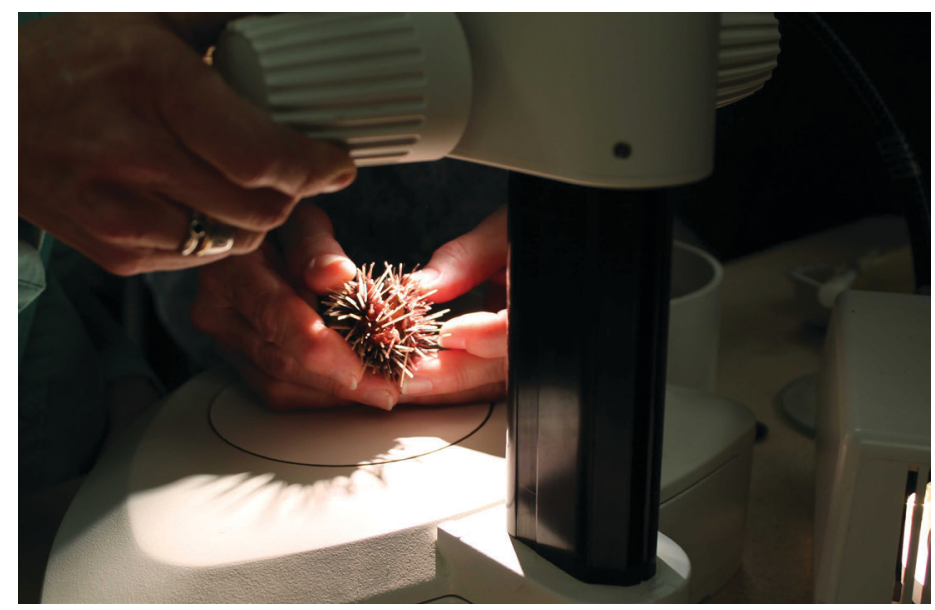

Figure 16. Using a dissecting microscope to examine $D$. antillarum. This animal was to be necropsied, so spines were cut prior to the exam. If the procedure is planned as a nonlethal exam, the spines should not be damaged.

Credit: R. Francis-Floyd, UF/IFAS

\section{Coelomic Fluid Collection}

Coelomic fluid is easily collected from this species and can be used for direct microscopic examination, cytology, microbial culture, immune function tests, and archival purposes. Martony et al. (2018) provided significant detail regarding needle size and placement using diagnostic imaging. A $3 \mathrm{~mL}$ syringe with a 21 gauge, 1 -inch needle is recommended. The needle should penetrate the periostomal membrane at an angle of $70^{\circ}$ and be directed away from the midline to avoid Aristotle's lantern (Figure 17). The depth of the needle penetration must be shallow to avoid contamination with gastrointestinal contents. For example, in a $78 \mathrm{~g}$ animal, the needle placement should be less than $7 \mathrm{~mm}$ to avoid puncturing the gastrointestinal tract (Martony et al. 2018).

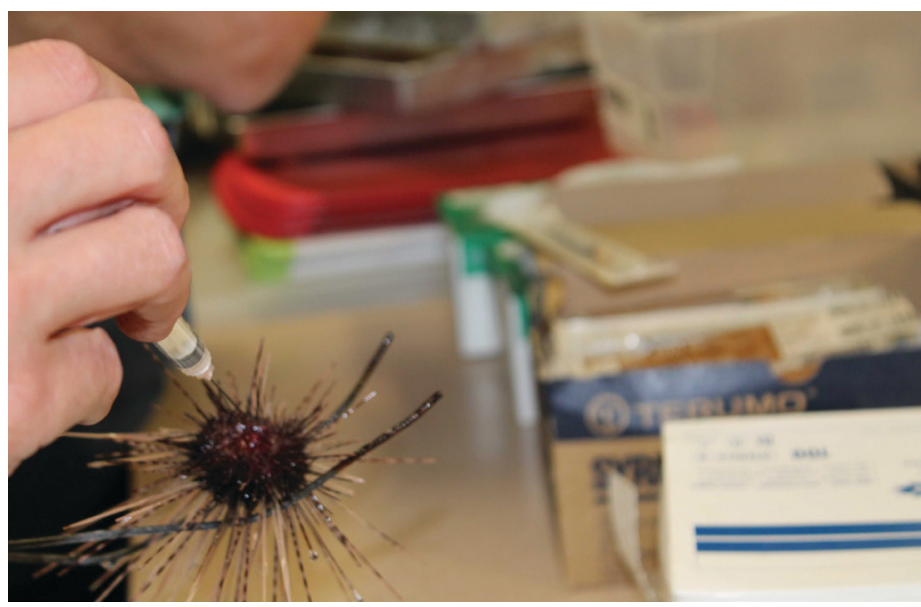

Figure 17. Collecting coelomic fluid from juvenile D. antillarum. A 1-inch, 21 gauge needle with an attached $3 \mathrm{~mL}$ syringe can be used to collect samples. The needle is inserted at an angle of $70^{\circ}$, directed away from the midline, and kept shallow to avoid contamination with gastrointestinal contents. Note that the striped spines visible on this animal suggest juvenile status. Also note that the sample is being collected without trimming the spines in a procedure which would be considered nonlethal. The animal is inverted and restrained with the tongs, allowing coelomic fluid collection without causing injury. This animal was not sedated for this procedure. MS-222 is an effective sedative to facilitate handling.

Credits: R. Francis-Floyd, UF/IFAS

Normal coelomic fluid should be clear, with a light pink coloration (Figure 18). Presence of dark brown material may indicate accidental contamination with gastrointestinal contents.

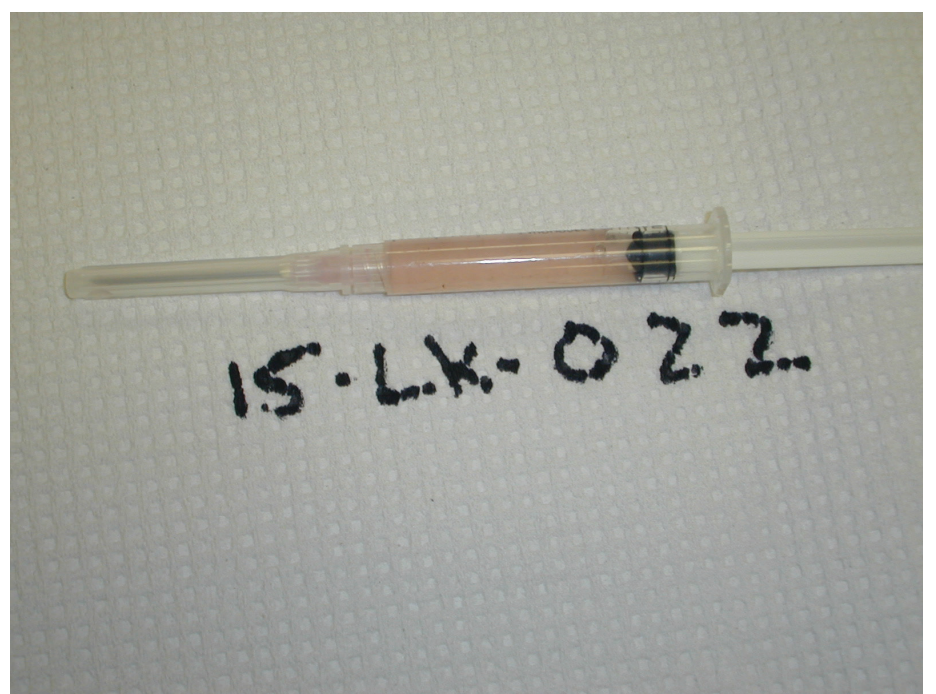

Figure 18. Normal coelomic fluid from D. antillarum. The fluid is clear but has a light pink color.

Credits: R. Francis-Floyd, UF/IFAS 


\section{Cytology}

Prepared direct smears of coelomic fluid and fecal material can be air-dried and stored for several months prior to staining with Wright-Giemsa (Figure 19). Using this method keeps cellular material fairly well preserved, but crystals and delicate proteinaceous materials may disintegrate.

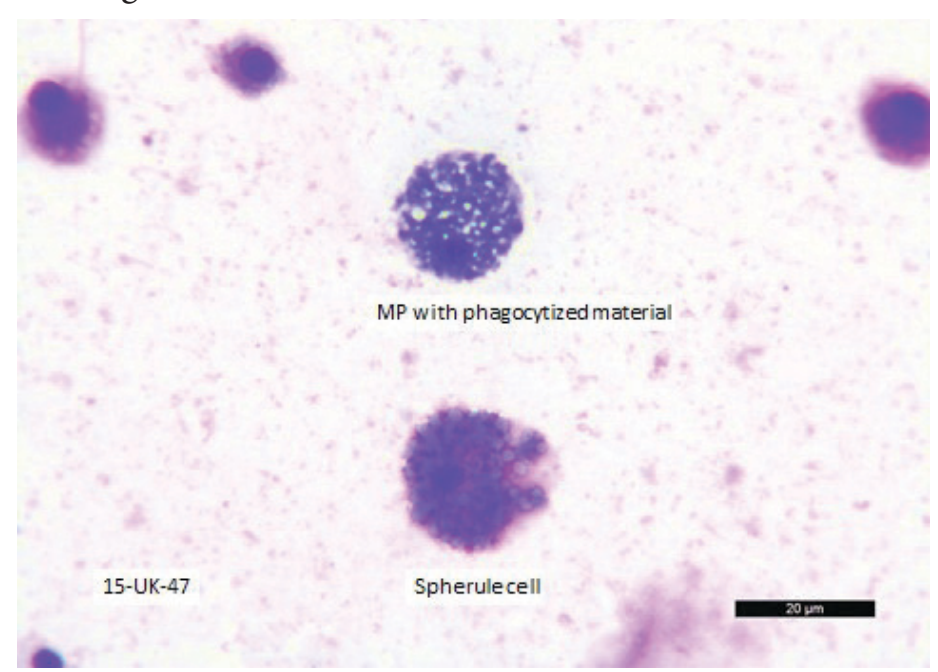

Figure 19. Coelomic fluid direct smears stained with Wright-Giemsa. $\mathrm{MP}=$ mononuclear phagocyte (or amoebocyte).

Credits: Nicole Stacy, UF College of Veterinary Medicine

\section{Microbial Analysis}

\section{Culture Techniques}

For animals without visible external lesions, bacterial cultures of coelomic fluid may be useful as an indicator of disease. However, potential for puncture of internal organs (including those of the digestive system) may result in sample contamination (Martony et al. 2018). Cultures of spines, or test with lesions, may be difficult to evaluate due to the normal presence of bacteria in seawater and current lack of information regarding "normal microbiota." Nevertheless, methodology for culture of spines is presented here for completeness.

\section{SUPPLIES AND EQUIPMENT}

- Scissors (for spine trimming)

- Hemostats

- 21 gauge, 1-inch needle

- $3 \mathrm{~mL}$ syringe

- Sterile cotton-tipped applicator (“swab”)

- Inoculating loops

- Sterile seawater in squirt bottle
- Tryptic soy broth $(5 \mathrm{~mL})$

- Tryptic soy agar with 5\% sheep's blood

- Gloves

- Reagent alcohol (ethanol, in small dip jar)

- Bunsen burner or alcohol burner (for flaming mouth of TSB tube for aseptic addition and removal of fluid and sterilizing inoculating loops)

- Test tube rocker

- Incubator (set at temperature of water where Diadema was collected)

Culture of spines (if lesion present):

1. Identify a spine at a lesion site.

2. Dip cool hemostats into a small container of reagent alcohol, remove, and carefully flame to sterilize the instrument.

3. Thoroughly (for approximately 5 seconds) flush the lesion and adjacent area with sterile seawater.

4. Using the cooled, sterilized hemostat, remove a primary spine at the lesion site by its base.

5. Aseptically place the spine with its base side down in a tube with $5 \mathrm{~mL}$ of tryptic soy broth (TSB).

6. Gently invert the inoculated TSB tube several times to mix.

7. Place the inoculated TSB tube on a test tube rocker and incubate for 24 hours.

8. After 24 hours, transfer inoculated broth to agar media.

a. Aseptically saturate a cotton-tipped applicator with the inoculated TSB.

b. Streak approximately $1 / 4$ of the agar plate with the inoculated swab.

c. Use two sterile inoculating loops to pull a second phase and then third phase (as if subculturing) (Figure 20).

9. Incubate at a temperature that closely approximates the temperature of the water from which urchins were taken for a minimum of 24 hours (up to 72 hours if no growth). 
10. Isolate each individual colony type for further diagnostics (bacterial identification, etc.). Note that different bacterial species may have similar colony types.

Culture of coelomic fluid:

1. Remove spines (only if this is a lethal examination) by trimming with scissors prior to collection of coelomic fluid. Be sure to wear safety glasses when trimming spines.

2. Flush the oral side of the urchin thoroughly for approximately 5 seconds with sterile seawater.

\section{Remove coelomic fluid.}

a. Carefully insert a 21 gauge, 1 -inch needle through the peristomial membrane near the mouth. Direct the needle at a $70^{\circ}$ angle away from the midline to avoid Aristotle's lantern (Martony et al. 2018).

i. Keep needle shallow (fewer than $7 \mathrm{~mm}$ in a $78 \mathrm{~g}$ urchin) and avoid repositioning to minimize the chance of puncturing the intestine.

b. Remove approximately $1 \mathrm{~mL}$ of coelomic fluid.

4. Aseptically add 2 drops of fluid per $\mathrm{mL}$ of tryptic soy broth (TSB).

5. Gently invert the inoculated TSB tube several times to mix.

6. Place the inoculated TSB tube on a test tube rocker and incubate for 24 hours.

7. After 24 hours, transfer inoculated broth to agar media.

a. Aseptically saturate a cotton-tipped applicator with the inoculated TSB.

b. Streak approximately $1 / 4$ of the agar plate with the inoculated swab.

c. Use two sterile inoculating loops to pull a second phase and then third phase (as if subculturing) (Figure 20).

8. Incubate for a minimum of 24 hours (up to 72 hours if no growth).

9. Isolate each individual colony type for further diagnostics (bacterial identification, etc.). Note that different bacterial species may have similar colony types.

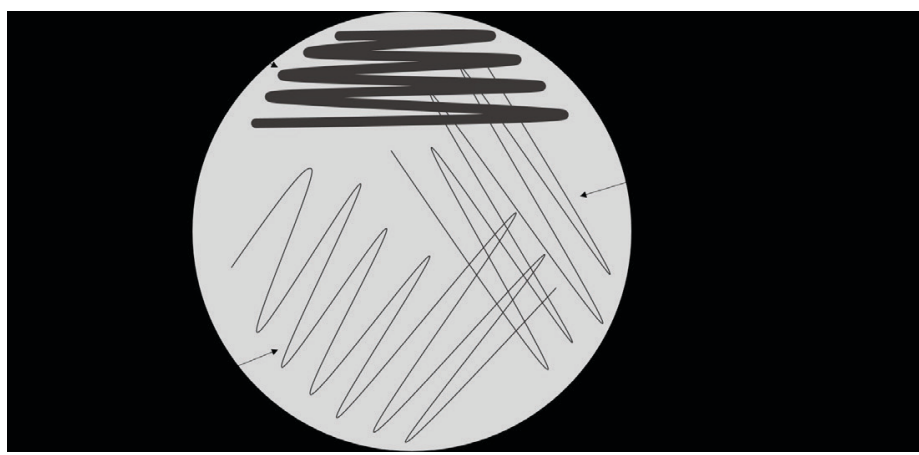

Figure 20. Plating out material collected from D. antillarum to create isolated colonies which can be subcultured for attempts at identification.

Credits: Deborah Pouder, UF/IFAS

\section{Use of Molecular Tools}

Tissues suitable for molecular analysis can be directly frozen without fixative and maintained at $-80^{\circ} \mathrm{F}$, or they may be preserved in RNAlater ${ }^{\circledast}$ prior to freezing. Tissues appropriate for archival or molecular use include test, spine, gut, gonad, and coelomic fluid. Archived samples may be submitted to an appropriate molecular lab for $16 \mathrm{~s}$ PCR sequencing (ideal for bacteria), 18s PCR sequencing (for protozoa), or more advanced analysis of the microbiome including Next Generation Sequencing methods. The UF Wildlife and Aquatic Veterinary Disease Laboratory (WAVDL) can run these analyses on a fee-for-service basis. For more information, contact Dr. Thomas B. Waltzek (tbwaltzek@ufl.edu).

\section{Use of Immune Function Tests}

Immune function tests for this species may not be commercially available. These services have been provided for various research projects by Dr. Greg Beck (University of Massachusetts, Boston campus). He has described immune function of D. antillarum in studies in the Caribbean (Beck et al. 2009) and more recently in Florida (Francis-Floyd et al. 2016).

For these studies, coelomic fluid can be collected as described above. It is mixed 1:9 with modified Alsever's anticoagulant (Table 1). Samples preserved using this method can be shipped on ice to an appropriate laboratory by an overnight delivery service. Assays to assess immune function may include cell counts, coelomic fluid protein concentration, humoral assays, and cytometry. 
Table 1. Recipe for modified Alsever's solution (provided by Dr. Greg Beck).

\begin{tabular}{|l|c|c|}
\hline \multicolumn{1}{|c|}{ Ingredient } & Amount & Concentration \\
\hline Glucose & $20.8 \mathrm{~g}$ & $115 \mathrm{mM}$ \\
\hline Sodium Citrate & $8.0 \mathrm{~g}$ & $27 \mathrm{mM}$ \\
\hline EDTA & $3.36 \mathrm{~g}$ & $9 \mathrm{mM}$ \\
\hline Sodium Chloride & $22.3 \mathrm{~g}$ & $336 \mathrm{mM}$ \\
\hline Distilled Water & $1.0 \mathrm{~L}$ & ------- \\
\hline
\end{tabular}

\section{Necropsy and Normal Anatomy}

Necropsy of the long-spined sea urchin should ideally be conducted either immediately after live collection (while in fresh condition before fixation) or following fixation in formalin and decalcification. The advantage of examining sea urchins immediately after euthanizing them is that the tissue coloration and texture resemble those of a living animal and can still be observed and recorded. If not observed immediately after the euthanasia (or death) of the animal, postmortem changes can occur, resulting in autolysis of tissues and colonization by exogenous or opportunistic organisms. Internal organisms may also be confused with perimortem infectious agents or conditions, which will confound the interpretation of results. Furthermore, motile organisms as well as the host's vibratile cells are readily detectable under wet mount microscopy of fresh dead, unfixed samples, and their mobility aids in microscopic observation (i.e., vibratile cells tend to be vigorously motile immediately following sea urchin sacrifice [or upon death]). However, if urchins are not examined quickly postmortem, their tissues may become discolored and autolysis will begin. Discoloration or fading may become more prominent the longer the tissues remain in the fixative, but this would not affect histological observation. It is beneficial and desirable when conducting a sea urchin necropsy to compare and contrast the structure and anatomy of the organs both in a fresh and a fixed and decalcified state in order to establish "normal-fixed" baseline parameters. Note that in the descriptions below, "test" is an anatomical term used to describe the hard outer surface of the sea urchin.

\section{Before Fixation}

1. After carefully removing the sea urchin from the seawater using tongs or large modified forceps and following the behavioral assessment, place the urchin on a scale and measure the wet weight $(\mathrm{g})$.

2. Cut the spines of the sea urchin with scissors (sharp/ blunt, surgical type, or shears), reducing them to a length of approximately $2-3 \mathrm{~cm}$. Safety glasses should always be worn when cutting sea urchin spines.
3. Using calipers, measure the diameter (at the equator of the urchin) and the height (oral to aboral axis).

4. Collect the coelomic fluid from the oral side of the peristomial membrane using a 21 gauge, 1 -inch needle and syringe $(3 \mathrm{~mL})$ for bacteriological, cytological, and immunological examination (see section on coelomic fluid collection for more information on positioning the needle and syringe to withdraw coelomic fluid).

5. Examine the external test surface grossly. Place the whole urchin specimen into a bowl or container with clean seawater and examine, utilizing the dissecting microscope and starting at the lowest possible power (e.g., 7.5x or 10x total magnification). Carefully examine the specimen for any fouling organisms, and observe the test color, the occurrence of mucus, and any abnormal conditions such as erosion or ulceration.

6. The sea urchin should then be bisected by cutting the test around the equator with a pair of scissors and separating the specimen into the oral (ventral) and aboral (dorsal) spheres.

7. Examine the internal organs grossly and use the dissection microscope to evaluate overall appearance and identify any abnormalities. The oral and aboral halves of each urchin specimen can be placed in a bowl and covered with seawater to aid in the examination and identification of organs.

8. Using a fine forceps and scissors, dissect small pieces of tissue from each representative organ, make wet mounts on glass slides, and examine them with a compound microscope, utilizing dry objective lenses $(40 \mathrm{x}-600 \mathrm{x}$ total magnification).

\section{After Fixation}

1. Follow steps 1 through 6 above for sample preparation for fixed materials.

2. Once the sea urchin is bisected into the oral and aboral hemispheres, fix each body half with $10 \%$ seawater formalin (see Appendix 5) to ensure penetration of fixative into the internal organs (Figure G1).

3. Use either a $250 \mathrm{~mL}$ or a $500 \mathrm{~mL}$ wide-mouth plastic container for smaller or larger sea urchins (juveniles [fewer than 40 to $50 \mathrm{~mm}$ in diameter] and adults), respectively. Make sure the volume of tissue to fixative ratio is at least 1:10 to allow for adequate fixation. Poor fixation can cause postmortem artifacts that can mislead diagnosticians. 
4. After at least 48-96 h of fixation, discard the fixative (in accordance with appropriate safety and environmental guidelines), and gently rinse the specimen with running tap water (for at least $30 \mathrm{~min}$ ) to remove any residual formalin.

5. Decalcify with $0.25 \mathrm{M}$ or $0.5 \mathrm{M}$ EDTA solution (Appendix 6) for $24 \mathrm{~h}$ for smaller individuals (including juveniles) or 24-48 h for adults, respectively. Ensure that the test tissues are decalcified well. After decalcification overnight or up to $48 \mathrm{~h}$, It should be possible to dissect out the test as readily as cutting a sheet of paper with scissors. However, if the tissue (especially the interambulacral area that has abundant spines) shows some resistance during dissection with scissors, extra time in EDTA will be required to decalcify. Particularly in adult specimens, the Aristotle's lantern will usually need extra decalcification time (4-5 days, depending on animal size) after being extracted from the other oral tissues. The solution should be changed daily with fresh decalcification solution (EDTA).

6. After appropriate decalcification in EDTA solution, thoroughly rinse off the EDTA solution with running tap water. Place the urchin samples in their original containers in tap water, then exchange with fresh tap water several times after soaking for approximately $30 \mathrm{~min}$.

7. Keep the oral and aboral halves of each urchin specimen separate in a container (e.g., glass bowl) filled with tap water while extracting individual tissues or organs. The water medium helps to suspend and separate each organ (e.g., intestine) and facilitates dissection. This method is useful after the test portion has been decalcified and turns soft and fragile. It is also beneficial for observation of organ location, close-up macrophotography (1x up to $10 \mathrm{x}$ magnification using a macro lens and extension tubes if necessary), and photomicrography (more than 10x magnification using dissecting microscope). Visually confirm each organ under a dissecting microscope using low power ( $7.5 \mathrm{x}$ or $10 \mathrm{x}$ total magnification), then use a pair of iris scissors and fine forceps (jewelers) to extract target tissues:

- Test: ambulacrum from oral sphere

- Test: ambulacrum from aboral sphere

- Test: interambulacrum from oral sphere

- Test: interambulacrum from aboral sphere

- Esophagus

- Small intestine

- Large intestine

- Aristotle's lantern with mouth attached

- Periproct, rectum, with madreporite attached
- Gill

- Gonad

- Axial organ and head process

- Lesioned areas or other tissues of interest

For juvenile specimens (as well as larvae if obtained from hatchery facilities) in which the test diameter is approximately $40 \mathrm{~mm}$ or fewer, it is more practical to process them for histology as a whole mount (as long as the sample fits into a tissue-processing cassette; see histology section below), rather than extracting each organ separately. The horizontally bisected sea urchin specimen can then be further sectioned into quadrants with oral to aboral cuts. This method allows the organs to be observed in situ on the histological slide.

8. Take photomicrographs of any interesting lesions or structures.

9. Place the tissues (approximately $<30 \mathrm{~mm}$ long $\times 26 \mathrm{~mm}$ wide $\times 5 \mathrm{~mm}$ thick) into a tissue processing cassette. The section can be supported by padding the inside of the cassette with a thin sponge (available from various histological supply companies) after arranging the tissue. Histology laboratories may pin the tissue to a piece of cardboard to avoid crushing the fragile organs after decalcification. This process is optional. Cassettes are then placed into a holding container with $70 \%$ ethanol.

10. Process tissues routinely in paraffin and/or JB-4 embedding media (see the next section).

11. Remaining tissue parts or organs can be archived in $70 \%$ ethanol if desired. 


\section{Normal Gross Anatomy and Grossly Recognizable Abnormalities}

\section{Normal Gross Anatomy}

The anatomical descriptions of the long-spined sea urchin follow the terminology used in Cavey and Märkel (1994) and Ziegler et al. (2009). A diagram of external anatomy has been included with the diagnostic evaluation form (see Appendix 2).

\section{INTEGUMENTARY SYSTEM (TEST)}

Externally, the test consists of ten pairs of ambulacral and interambulacral plates (Figures G1 and G2). On the ambulacral plate, tube feet (podia) are most abundant on the oral hemisphere. Spines and pedicellariae are present on the external surface (Figures G21-s). Spines are abundant on the interambulacrum. Pedicellariae are observable with the aid of a dissecting microscope and are commonly abundant on the oral hemisphere, especially near the gill tissues. Blue-violet iridophores are located around the aboral plate and radiate around the ambulacral plate (Figures G2n-o).

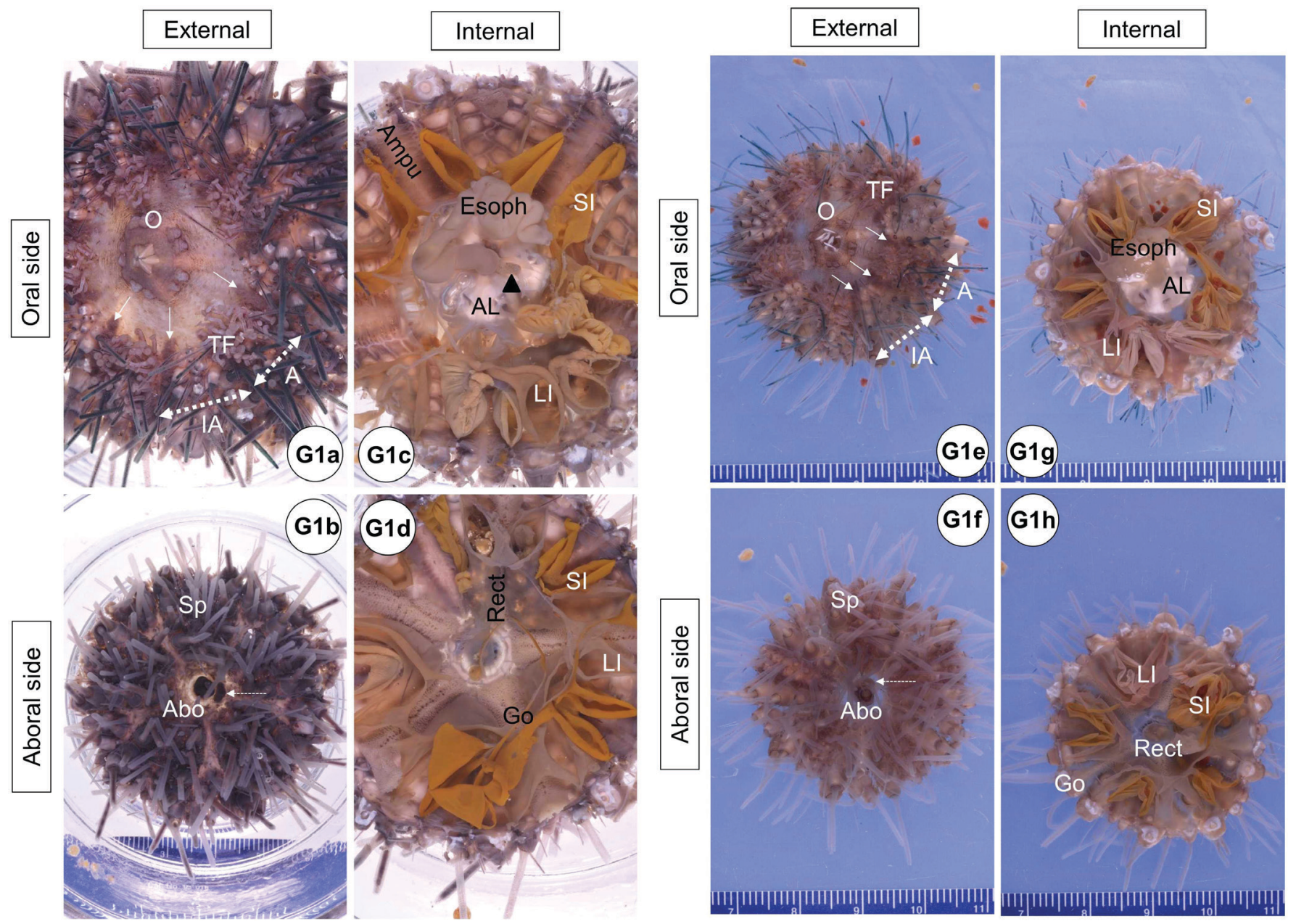

Figure G. Figures G1-G10: All Diadema antillarum specimens were formalin fixed, followed by decalcification with EDTA, and photomicrographed with dissecting microscope, except for Figure G1 which was macrophotographed, and Figure G9f (tissue wet mount slide) which was used with light microscope. Most of the photographs were taken for the adult specimens, unless clearly noted as juvenile.

Figure G1. Gross anatomical overview of adult $(a-d)$ and juvenile $(e-h)$, captured in spring (March) and fall (September), respectively. External (a, $b, e, f)$ and internal $(c, d, g, h)$ surface view of the oral $(a, c, e, g)$ and aboral $(b, d, f, h)$ side hemispheres. A (between thick double-dashed arrow) = ambulacrum; Abo = aboral; AL = Aristotle's lantern; Ampu = ampulla; arrow head = axial organ; Esoph = esophagus; Go = gonad; IA (between thick double-dashed arrow) = interambulacrum; $\mathrm{LI}=$ large intestine; $\mathrm{O}=$ oral; $\mathrm{Rect}=$ rectum; $\mathrm{SI}=\mathrm{small}$ intestine; $\mathrm{Sp}=\mathrm{spine}$; $\mathrm{TF}=\mathrm{tube}$ foot; white dashed arrow = madreporite; white solid arrows = gill."

Inside the test, ampullae are located on the ambulacral plates (see also water vascular section), and the gonads and gastrointestinal system are located near the interambulacral plates, especially in the aboral hemisphere (see also gastrointestinal and reproductive systems of normal gross anatomy). 

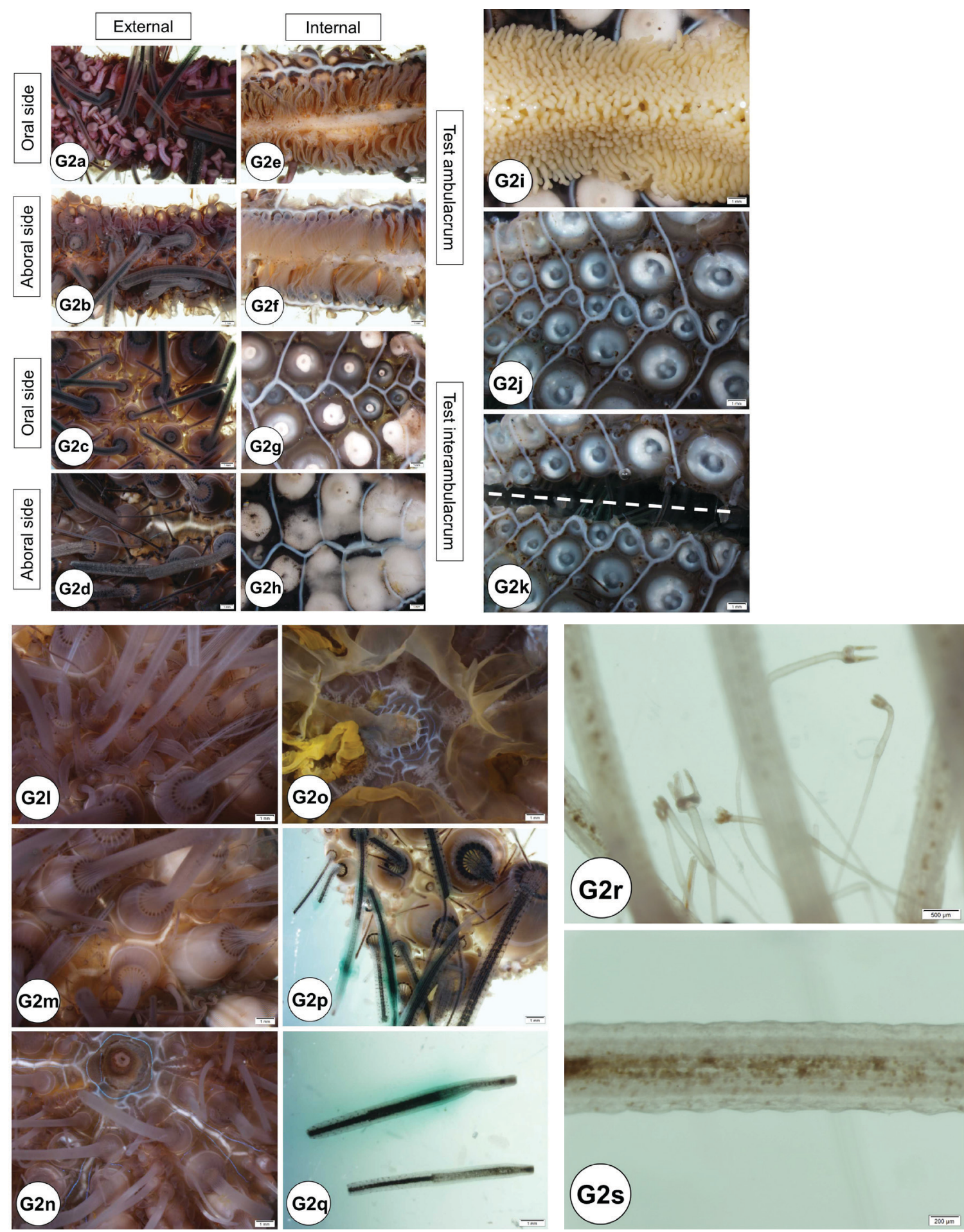

Figure G2. Test and appendages. (a) External view of the test ambulacrum of oral area. (b) External view of the test ambulacrum of aboral area. (c) External view of the test interambulacrum of aboral area. (d) External view of the test interambulacrum of aboral area. (e) Internal view of the test ambulacrum of oral area showing ampulla. (f) Internal view of the test ambulacrum of aboral area showing ampulla. ( $g$ ) Internal view of the test interambulacrum of oral area after the intestine removed. (h) Internal view of the test interambulacrum of aboral area after the gonad removed. (i) Internal view of the test interambulacrum of aboral area before the gonad (histologically confirmed as ovary) removed. Some spines were still not completely decalcified in this specimen. (j) Internal view of the test interambulacrum of oral side after the intestine and gonad removed. (k) Same view of (j) but the test can be easily longitudinally sectioned with scissor (indicated with dashed white line) because the spines were completely decalcified for this specimen. (I) External view of the aboral side of the test ambulacrum plate. (m) External view of the aboral side of the test interambulacrum plate. (n) External view of the aboral area of test plates of juvenile sample exhibiting with blue-violet iridophores radiate around the ambulacral plate. (o) Internal view of (n). (p) External view of oral side of the test interambulacrum plate with spines having peculiar water-soluble greenish pigments. (q) Spines of (p) removed. (r) Spines and pedicellariae from aboral side of the test of ambulacrum plate. (s) Melanin pigments are commonly found at the center core of the spine, especially at the shaft portion (e.g., see histology figure, Figure H10). 


\section{WATER VASCULAR SYSTEM (WVS)}

Ampullae (one for each tube foot) are located internally on the ambulacral plates. The madreporite is attached externally to the periproct (see gastrointestinal system of normal gross anatomy) and forms a sieve-like structure on the aboral surface (Figure G3). The ampullae and madreporite are connected to the stone canal and the ring canal. The WVS also includes radial canals that run inside the ambulacral areas, and lateral canals that terminate in the tube foot ampullae. The WVS functions for locomotion, nutrition, and respiration (see also water vascular system in the Normal Microscopic Anatomy section).
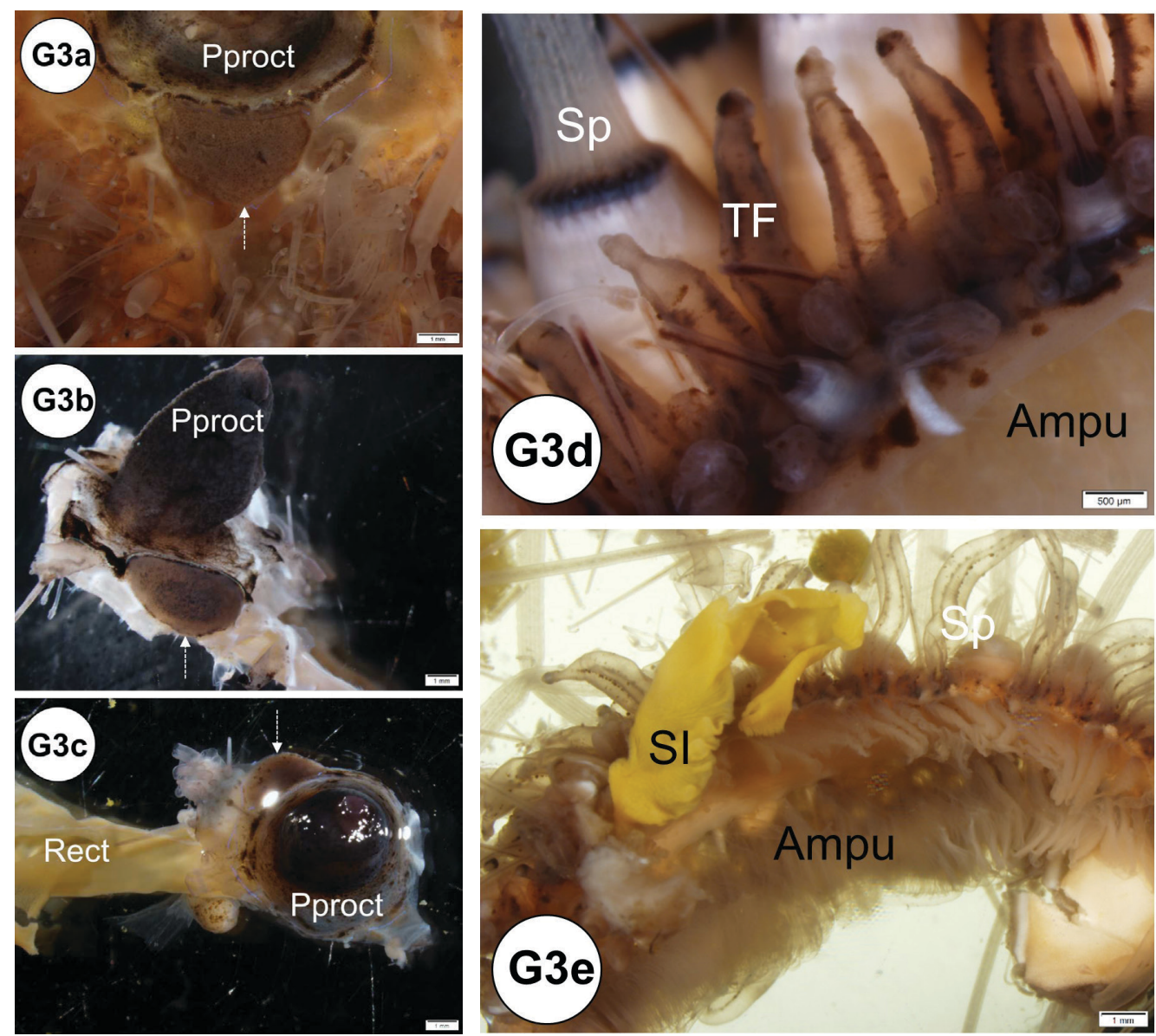

Figure G3. Water vascular system. (a) Aboral area showing madreporite and periproct. (b) Extracted organs of madreporite and periproct (slightly prolapsed opening of anus). (c) Rectum, periproct, and madreporite were extracted. (d) Longitudinally sectioned view of the test showing the tube feet, spines, and ampullae. (e) Lateral-ventral sectioned view of the test showing the spines, ampullae, and piece of small intestine. Ampu = ampulla; Pproct = periproct; Rect = rectum; $\mathrm{SI}=$ small intestine; $\mathrm{Sp}=$ spine; $\mathrm{TF}=$ tube foot; white dashed arrow = madreporite.

\section{HEMAL SYSTEM}

The hemal system consists of a network of vessels in the wall of the gut mesenteries and the axial complex. The axial complex includes the head process (aboral diverticulum) and an axial organ (gland), connected by the axial duct (Cavey and Märkel 1994). The function of the axial organ remains uncertain, but some hypotheses are: movement of fluid and pulsation (heart), coelomocytes production (hematopoietic), cell degradation and excretion site, or defense (immune) (Ziegler et al. 2009). The axial organ and the head process are small (5-7 mm long) but grossly visible, especially in adults (Figures G4a-d). They run aboral to oral, parallel to the WVS (madreporite/ring canal/stone canal) and the Aristotle's lantern. Depending on age, the axial complex usually contains melanin aggregates. In adults, the bean-shaped axial organ is usually elongated and located around the esophagus as it exits the Aristotle's lantern. The axial organ may also be easily identified at the head process near the rectum at the periproctal sinus. Using a dissecting scope, the organs can be extracted with fine scissors and forceps and processed for histology. The hemal vessels are seen grossly, particularly when attached to the small or large intestines (Figures G4e-f). These vessels also may contain melanin (Figure G4e). 


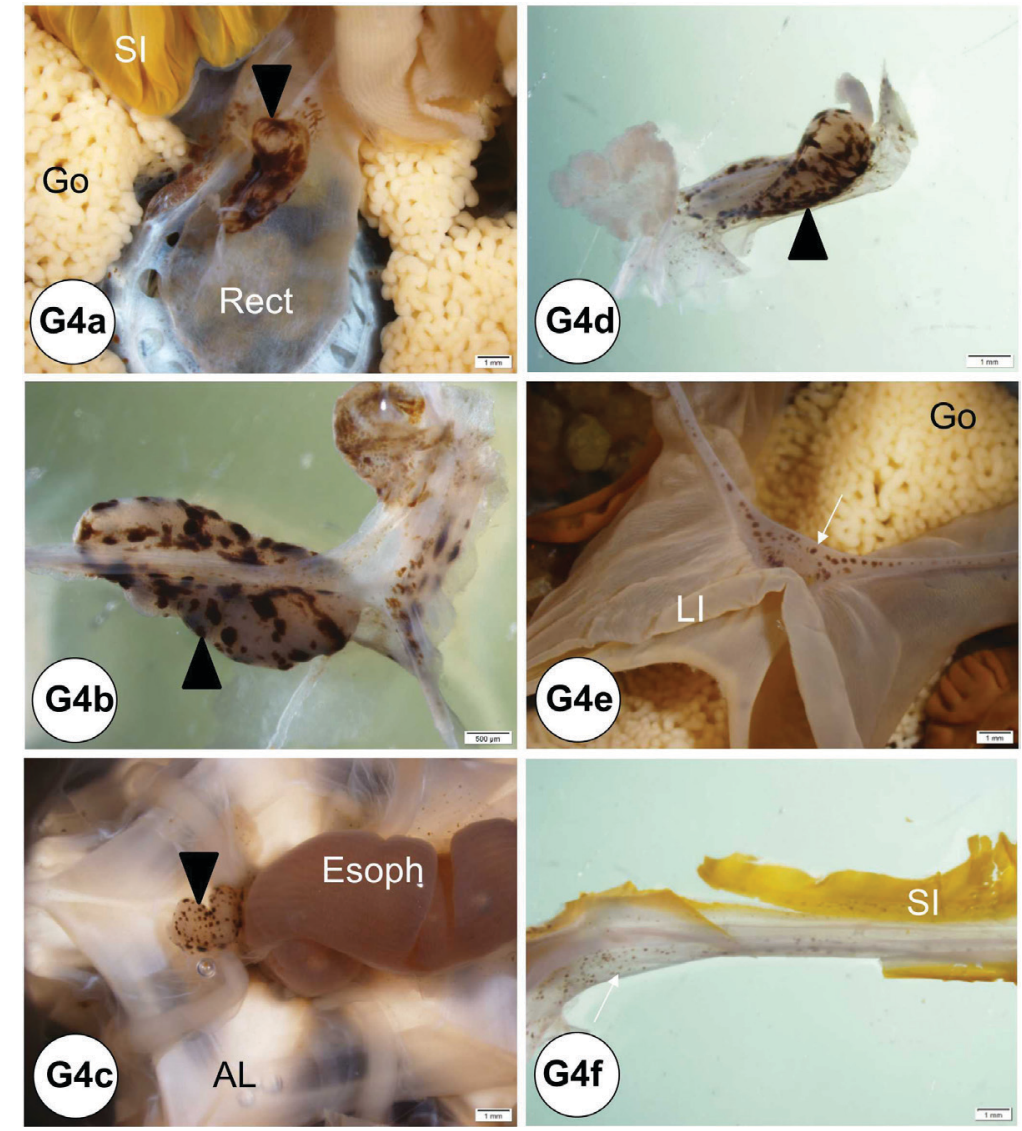

Figure G4. Hemal system. (a) In situ view showing location of the axial organ at the aboral side. (b) Extracted axial organ. (c) In situ view showing location of axial organ at the Aristotle's Lantern and esophagus connection area. (d) Extracted axial organ. (e) In situ view showing location of hemal vessel attached to the large intestine. ( $f$ ) Extracted hemal vessel attached to the small intestine. AL = Aristotle's lantern; Arrow $=$ hemal vessel; Arrow head = axial organ; Esoph = esophagus; $\mathrm{Go}=$ gonad; $\mathrm{LI}=$ large intestine; Rect = rectum; $\mathrm{SI}=$ small intestine.

\section{GASTROINTESTINAL SYSTEM}

\section{i. Aristotle's lantern}

At the oral surface, the mouth is located at the center of the peristomial membrane, which is attached internally to Aristotle's lantern. Five specialized tube feet (modified tube feet; buccal podium) project from the membrane around the mouth and five pyramidal teeth fill the mouth opening (Figures G5a-c). Note that when a coelomic fluid sample is taken using a needle and syringe, the needle is inserted through the peristomial membrane (Figures G5a, c, d). The Aristotle's lantern is suspended by the protractor and retractor muscles (Figures G5e-f) attaching to the pyramid (i.e., jaw). If the peristomial membrane is detached from the lantern by circumferentially cutting the former with a pair of scissors, and then crosscutting the muscles, the lantern can be isolated readily. The mouth, the buccal cavity, and the pharynx run longitudinally through the center of Aristotle's lantern.

\section{ii. Alimentary tract}

The esophagus, small and large intestines, rectum, and anus (periproct) can be grossly differentiated (Figures G1b, d, G6). The light-brown, transparent esophagus connects the Aristotle's lantern (Figure G6a) and the small intestine (Figure G6b). Longitudinally oriented grooves are visible on the external surface of the esophagus (Figure G6a). After formalin fixation, the small intestine is usually bright yellow (Figures $\mathrm{G} 6 \mathrm{~b}-\mathrm{d}, \mathrm{g}$ ). The small intestine connects to the large intestine, which is light yellow (Figures G6c-d, g) and narrower (or thinner) compared to the small intestine. The intestinal color may vary depending on the urchin diet. Food items, especially digested pigmented material (e.g., macroalgae), can change the normal intestinal color from a light yellow to various shades of red (e.g., if from Rhodophyta) (Figures G10a-b). The rectum connects the large intestine and the periproct with an external opening at the anus (Figures G6e-f). Like the esophagus, the rectum has longitudinally oriented ridges and grooves (Figure G6e). The black to brown periproct protrudes (Figure G6f) at the external surface, occasionally expanding and becoming balloon-shaped (Figure 10g). 


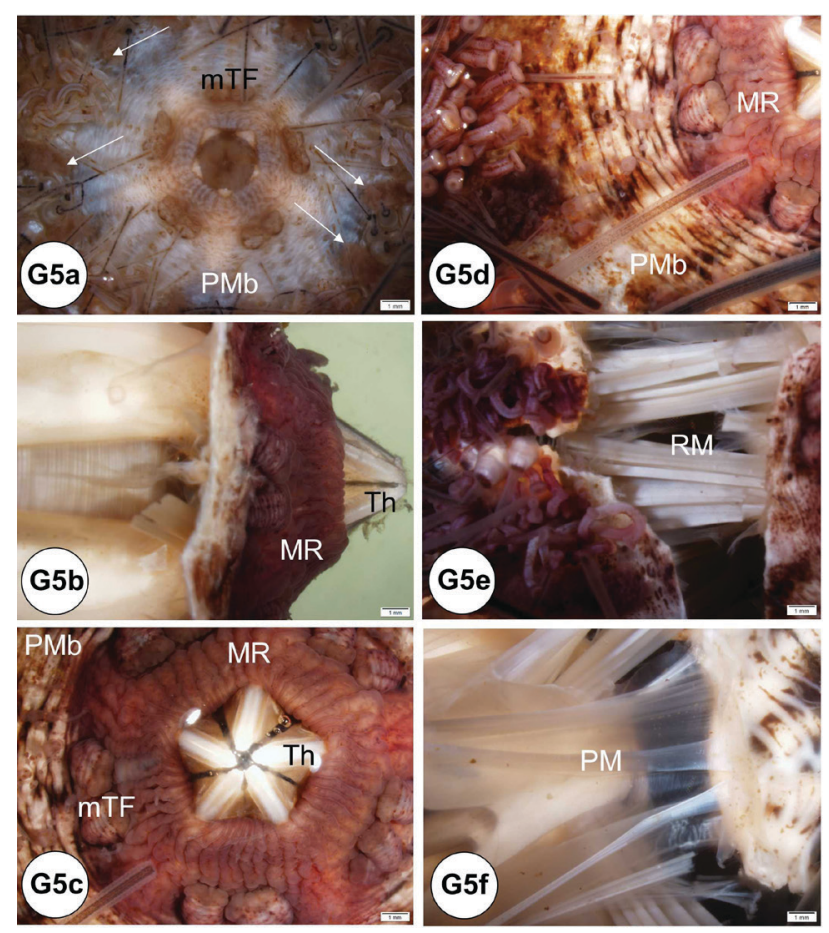

Figure G5. Aristotle's lantern. (a) Oral area showing the gill, modified tube foot, and peristomial membrane. (b) Longitudinal view of the Aristotle's lantern, mouth rim, and teeth. (c) Oral area showing the peristomial membrane, mouth rim, teeth and modified tube feet. (d) Close up view of the peristomial membrane, oral mouth rim, and teeth. (e) Retractor muscle tissue. (f) Protractor muscle tissue. Arrows = gill; MR = mouth rim; $\mathrm{mTF}=$ modified tube feet (=buccal podium); $\mathrm{PM}=$ protractor muscle; $\mathrm{PMb}=$ peristomial membrane; $\mathrm{RM}=$ retractor muscle; Th $=$ teeth.
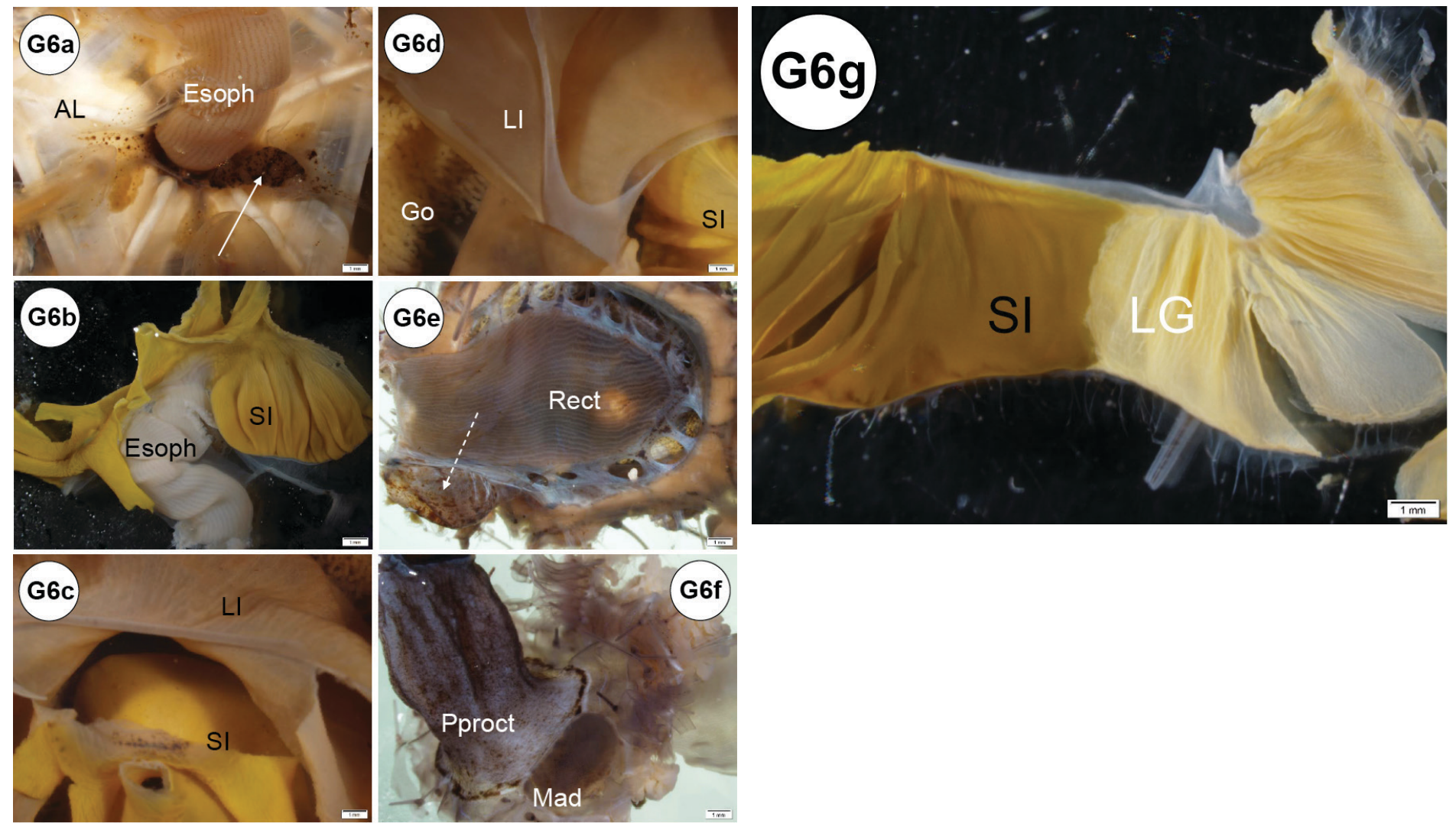

Figure G6. Gastrointestinal tissues. (a) Esophagus connects at the Aristotle's lantern and axial organ. (b) Small intestine connects to the esophagus junction. (c) Large and small intestine. (d) High-magnification view of the large intestine and orientation to the gonad and small intestine. (e) Extracted view of the rectum and head process (= aboral diverticulum) which connects to axial organ. (f) Periproct and madreporite. (g) Transition between small intestine and large intestine. AL = Aristotle's lantern; Arrow = axial organ; Dashed arrow = head process; Esoph = esophagus; Go = gonad; LI = large intestine; Mad = madreporite; Pproct = periproct; Rect = rectum; SI = small intestine. 


\section{REPRODUCTIVE SYSTEM}

A creamy-white to bright-yellow gonad is attached internally on each interambulacral plate, with five gonads present in total (Figure G7a). The gonads are largest towards the aboral portion of the test where they are attached to one of the five gonadal plates (Figures G7a-e). The gonads may be large in the fall just before spawning. Maximum gonadal indices for Diadema in the Florida Keys have been observed in the late fall (October to December) (Bauer 1976). In some cases, when a fully mature testis is cut, contact with fixative, water, or alcohols may result in the release of sperm in a milky "cloud" (Figure G7f). Although not observed in this study, eggs may be released from the ovary in a similar manner. The immature gonads of juvenile specimens are hard to visualize grossly. It may be difficult to differentiate gender grossly, and wet mount observation or histological confirmation of gonadal tissue using light microscopy is required.
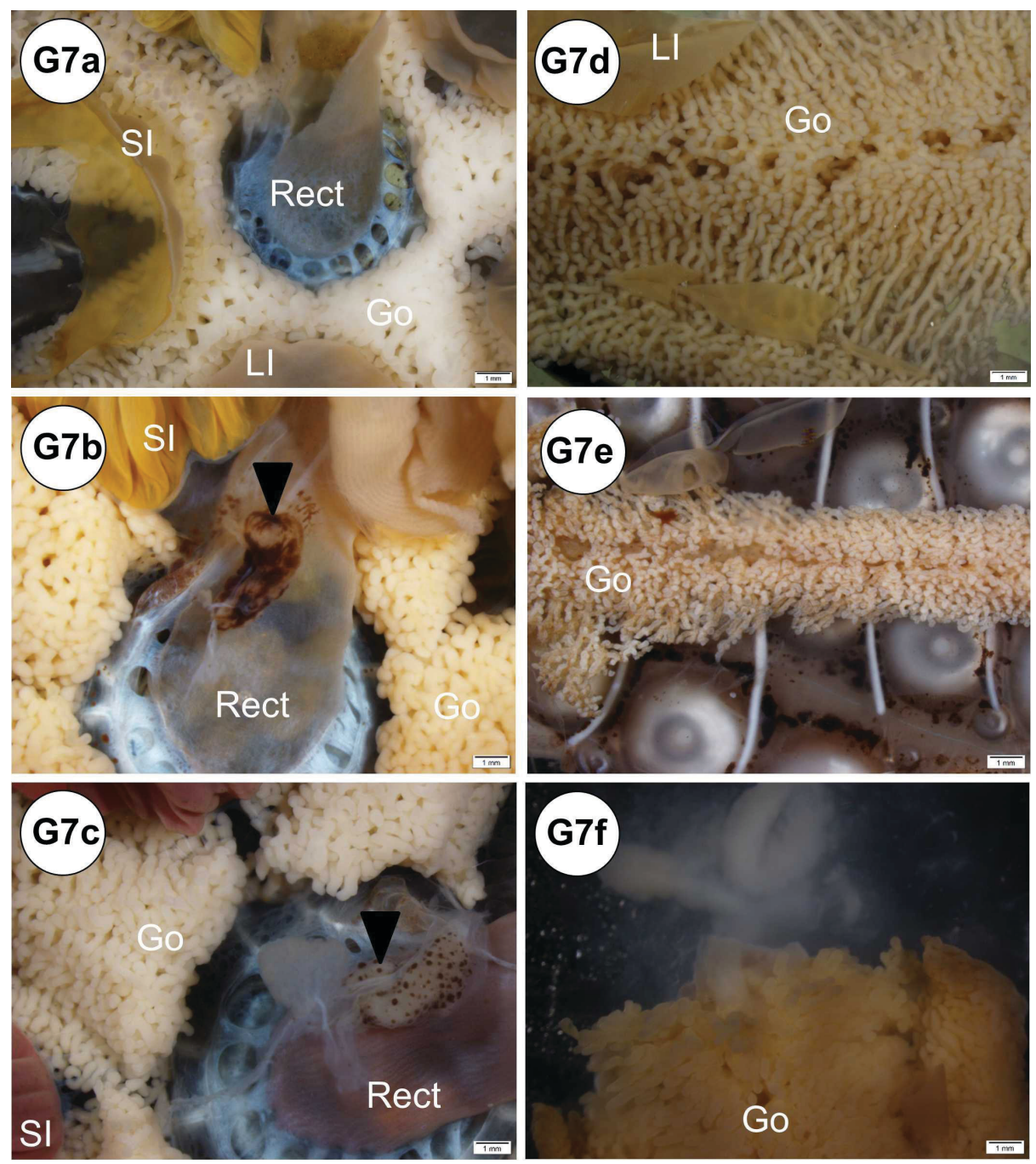

Figure G7. Reproductive organs. (a) Gonad tissues (histologically confirmed as testis) are attached to the interambulacrum plates, mainly at the aboral side. (b) In situ view of gonad (histologically confirmed as testis) at aboral area. (c) Another in situ view of gonad (histologically confirmed as ovary) at aboral area. Note that this specimen had reddish small intestine due to the diet. (d) Gonad extracted (histologically confirmed as ovary). (e) Gonad tissue (histologically confirmed as ovary) appeared to be atrophied. (f) Gonad (histologically confirmed as testis) with cloudy substances (i.e., presume sperm) escaping from the cut surface after dissecting out the organ. Arrow head = axial organ; Go = gonad; LI = large intestine; Rect = rectum; $\mathrm{SI}=$ small intestine.

\section{RESPIRATORY SYSTEM}

Most respiration occurs across the tube feet (found on the ambulacral test) and the 10 brown to reddish gills (found on the peristomial membrane as outpockets of the peripharyngeal [lantern] coelom) between the ambulacral and interambulacral plates (i.e., at the edge of each interambulacral plate) (Figure G8).

\section{NEURAL SYSTEM}

Grossly, nerve tissues are difficult to identify. 


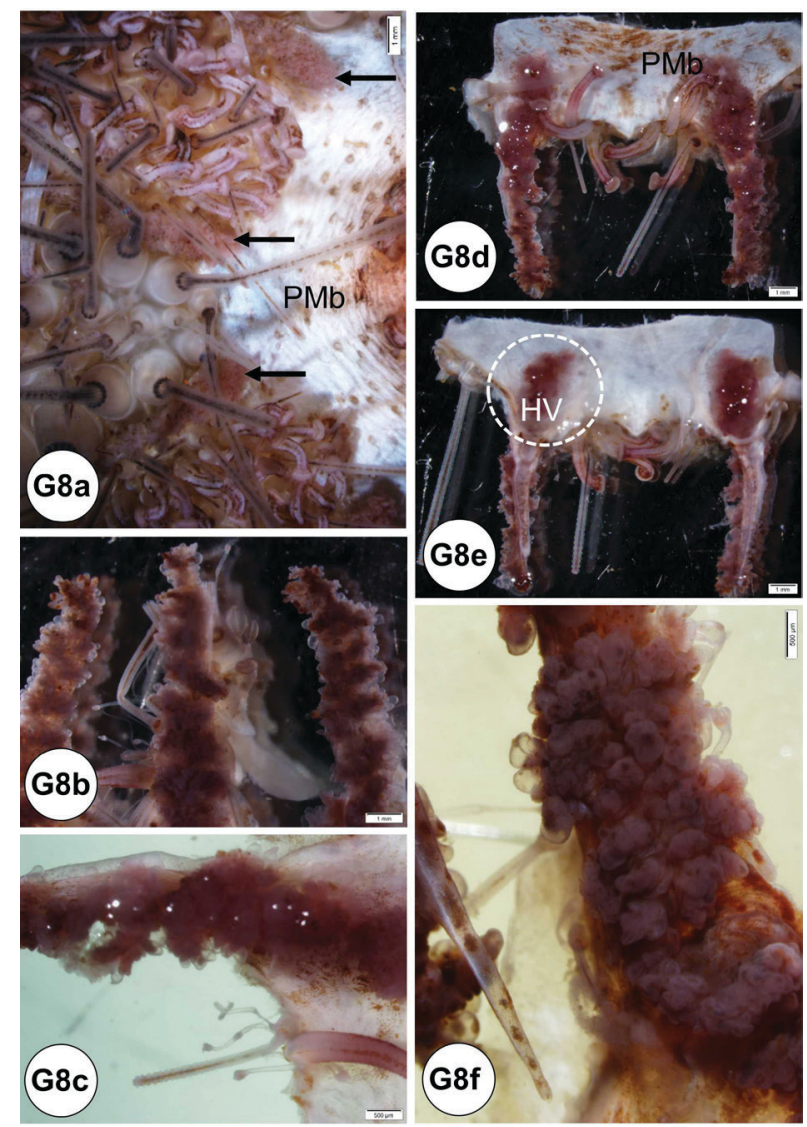

Figure G8. Respiratory system. (a) In situ gill attached to the peristomial membrane. (b) Three gills extracted view. (c) High-power magnification view of extracted gill with pedicellariae also seen in this image. (d) Extracted two gills oriented to the up right position (i.e., front side) view attached to the peristomial membrane. (e) Extracted two gills flipped over view of (d) showing the underneath (i.e., backside) view and large hemal vessel revealed (surrounded by dashed circle area). (f) Outer surface area of gills exhibiting numerous sac-like structures. Arrow = gill; PMb = peristomial membrane; $\mathrm{HV}=$ hemal vessel.

\section{Examples of Grossly Recognizable Abnormalities OOCYTES ON SURFACE OF THE GILL AND TEST}

During gross processing of tissues, some examples of noticeable abnormalities can be identified (Figures G9a-f). Utilizing a dissecting microscope, oocytes can be detected on the surface of the gills (Figures G9a-b), both the external and internal side of the test (Figures G9c-e), and on the ampullae (figure not shown). The oocytes were confirmed by tissue wet mount (Figure G9f). The condition was found only in samples from adult (mature) females collected in September (90\% [n =20]; see histology, disease, and abnormalities section).

\section{ARTIFACTUAL NEEDLE PUNCTURE MARK AT THE PERISTOMIAL MEMBRANE}

When collecting coelomic fluid, especially in juvenile specimens, needle puncture marks have been found at the peristomial membrane in some specimens (Figures G9h-i). This may have been caused by a large gauge needle (21 gauge, 1-inch) for coelomic fluid collection in small urchins. Coelomic fluid was successfully drawn without leaving a needle mark at the peristomial membrane for this juvenile specimen (Figure G9g). See below: artifactual needle puncture mark on the intestine.

\section{BROWN PIGMENTATION IN THE AMPULLAE}

Brown pigments were found in the ampullae of both oral and aboral sides (Figures G9j-1). Histologically, these brown pigments appeared to be melanin.

\section{SPINE TUBERCLE}

If a spine is pulled out or broken, the spine tubercle may be visible on the surface of the test (Figure G9m). Healing of this type of wound may be indicated by a shiny appearance (Figure G9n). 


\section{BROWN PIGMENTATION IN THE HEMAL VESSEL}

Brown pigments were found in the hemal vessels (Figures G9o-p). These pigments appeared to be melanin or melanized hemocytes (see below: histology in hemal and respiratory [gill] systems).
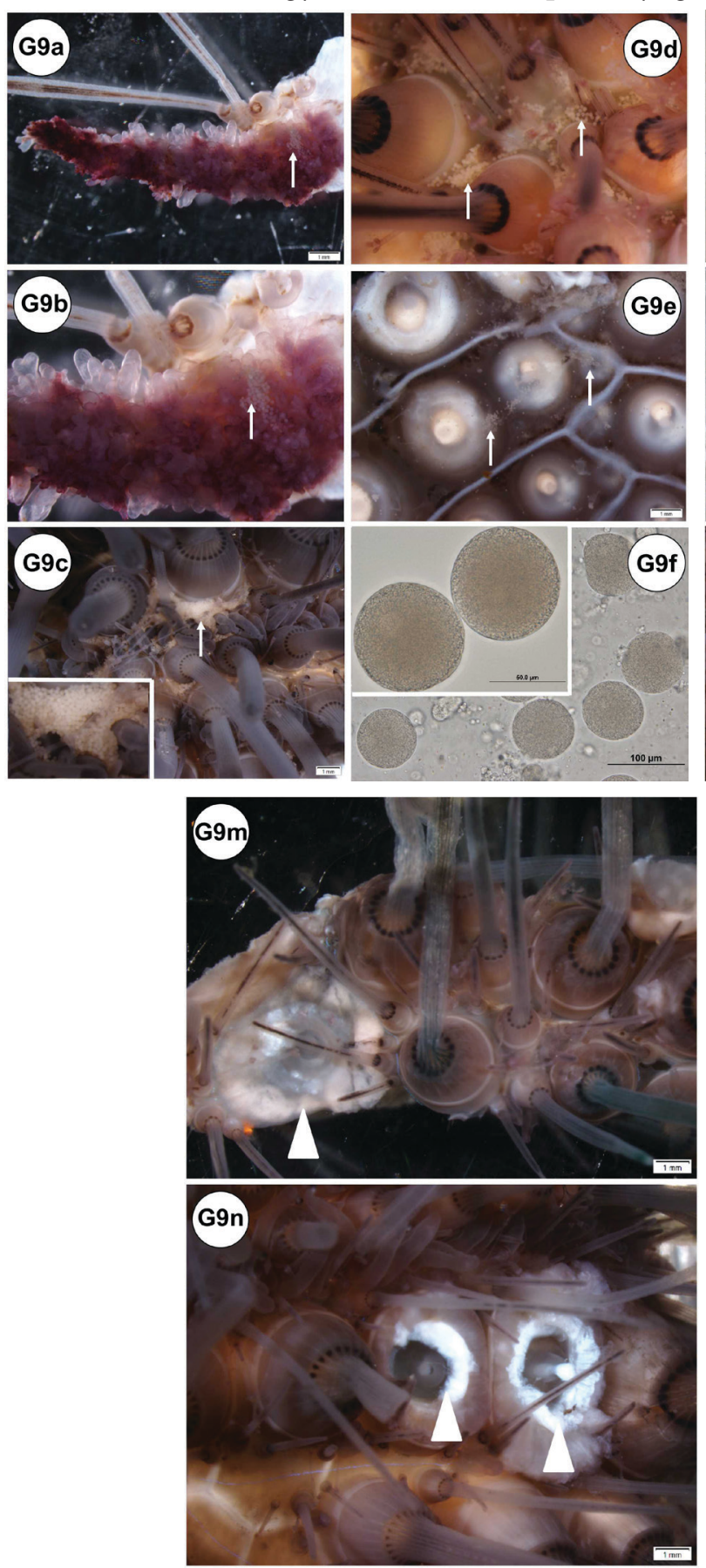
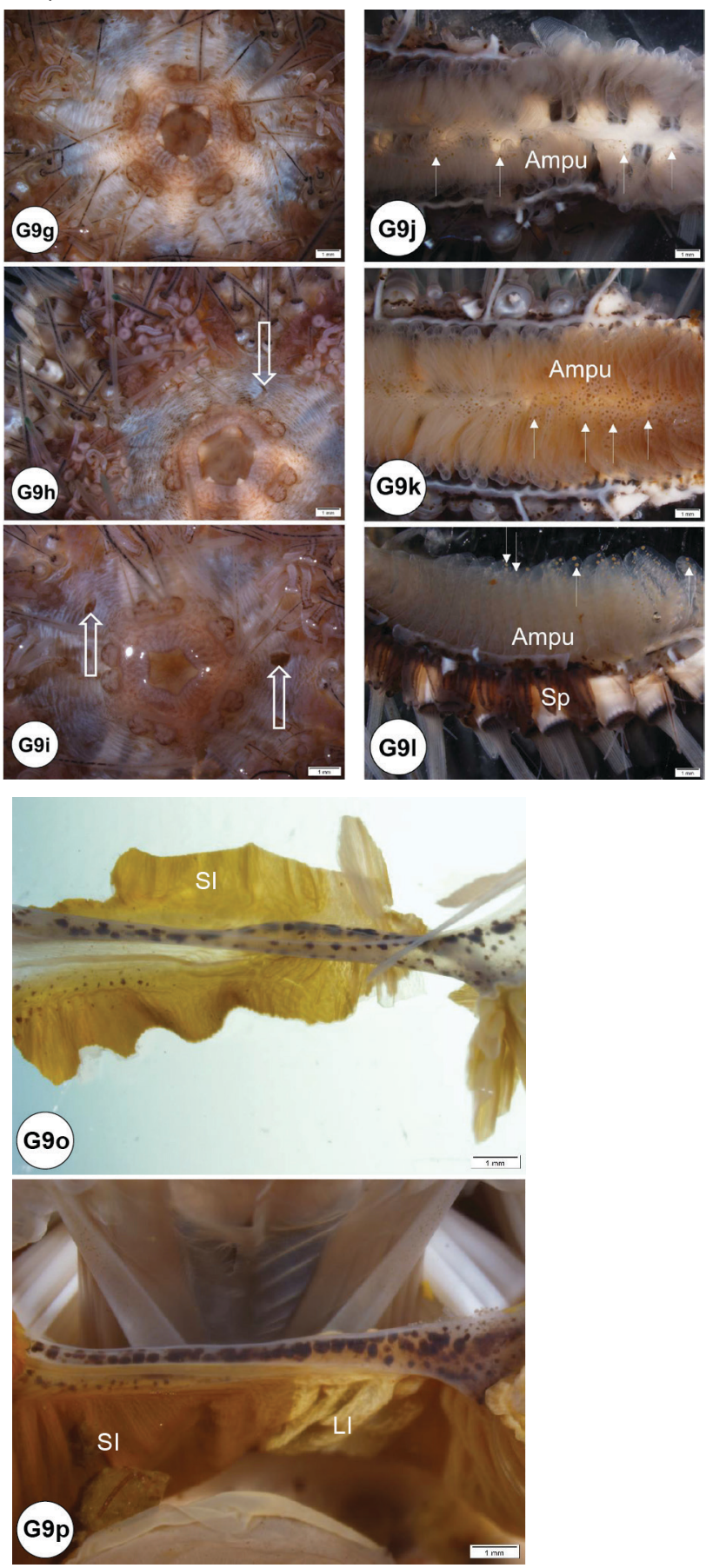

Figure G9. Gross recognizable abnormalities (some pathologies) shown. (a) Gill that had oocytes adhered at the surface of mature female specimen. (b) Enlarged view of (a). (c) Test with oocytes adhered at the surface of mature female specimen. Inset of (c) showing high magnification of oocytes (white thick arrow). (d) Test external view. (e) Test internal side view of (d). (f) Tissue wet mount taken from the oocytes adhered to the test surface of (c). Inset of ( $f$ ) showing high magnification of the tissue wet mount of oocytes taken from the test surface of (d). Note that these oocytes possibly originated from fully mature female Diadema (see histology, disease and abnormalities section). (g) Normal view of peristomial membrane of juvenile. (h-i) Artifact needle puncture mark (hollow white arrow) of juvenile specimens. (j) Brown pigmentation in the ampullae of ambulacrum test plate of aboral side. (k) Brown pigmentation in the ampullae of ambulacrum test plate of oral side. (l) Longitudinally sectioned view of the ambulacrum test plate showing the brown pigmentation in the ampullae. (m) Spine tubercle shown where the spine itself was broken or pulled out. (n) Same specimen as (m), but the area had two spine tubercles, and healing occurred indicated by shiny appearance. (o) Brown pigmentation in the hemal vessel of small intestine. (p) Brown pigmentation in the hemal vessel of both small and large intestine border. Ampu = ampulla; Arrow head = spine tubercle; Hollow white arrow = needle puncture mark; $\mathrm{LI}=$ large intestine; $\mathrm{SI}=$ small intestine; $\mathrm{Sp}=$ spine; White thick arrow = egg mass; White thin arrow = brown pigmentation. 


\section{RED ALIMENTARY TRACT}

For the samples collected during fall, red intestines were found predominantly in juveniles (Figure G10a) but some were also observed in tissues from adults (Figure G10b). Both large and small intestines were colored red, but the large intestine was typically more affected. The condition may be artifactual. The coloration may have originated from the macroalgae (presumably Rhodophyta) fed to these Diadema during a holding period.

\section{PERIPROCT (ANUS) CONDITIONS}

In some specimens, the periproct region exhibited lesions: erosion (Figures G10c-d), nodule formation (Figure G10e), and elongation (Figure G10f). Periproct prolapse (enlarged or swollen; Figure G10g) was observed, but it is not known if this is normal or indicative of disease. In situ view of elongated and nodular periproct shown (Figures G10h-j).

\section{ARTIFACTUAL NEEDLE PUNCTURE MARK AT THE INTESTINE}

Microscopically visible needle punctures are found in the wall of the gut of some animals. Perforations of the small intestinal tract are believed to be caused by needles during collection of coelomic fluid and are more common in smaller specimens (Figures G10k-p). Observation of this artifact may be important when trying to interpret positive bacterial cultures from coelomic fluid (Figures G10q-r).

\section{BLACK SPOTS}

Black spots found at mesenteries of the esophagus (Figures G10s-t).
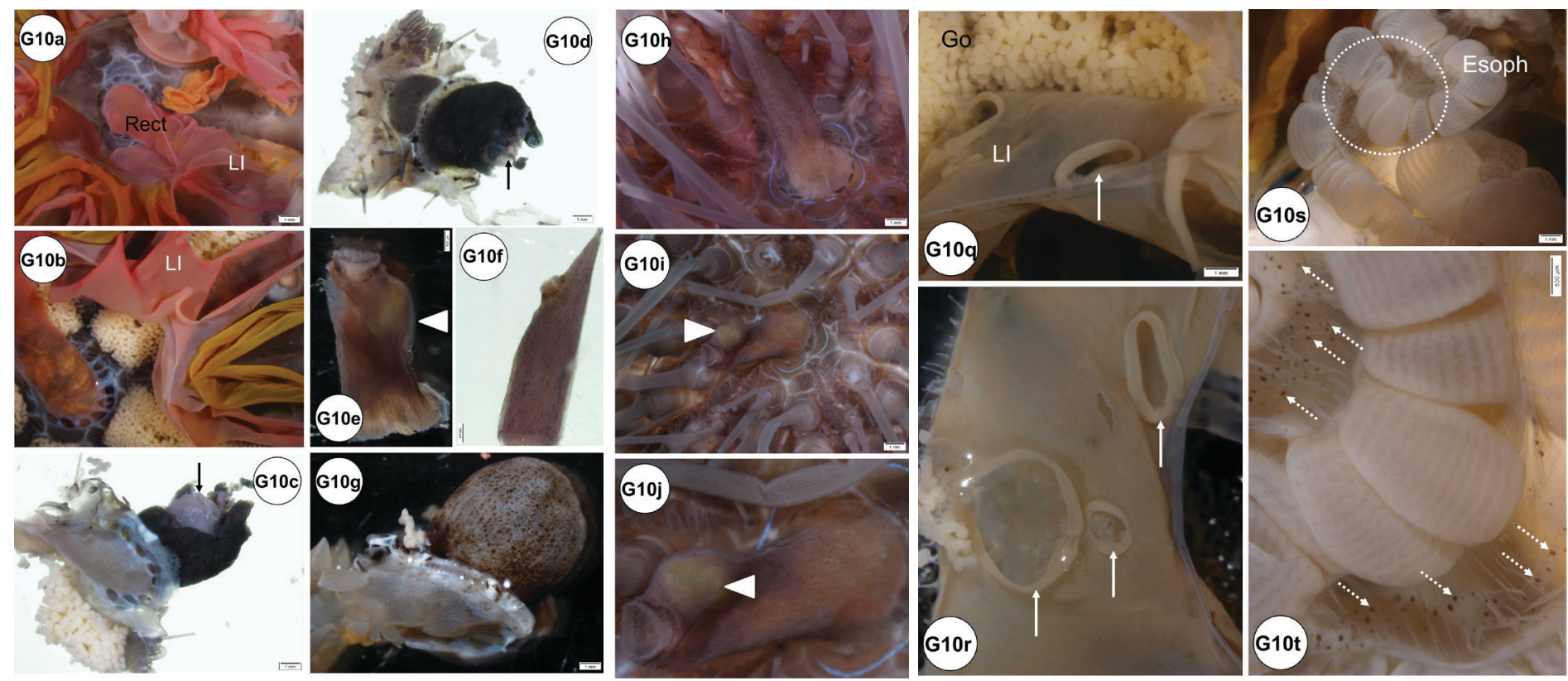

Figure G10. Gross recognizable abnormalities (some pathologies) shown. (a) Red alimentary tract of juvenile specimen. (b) Red alimentary tract of adult specimen. (c) Erosion (arrow) of periproct of adult specimen. (d) Another angle view of (c). (e) Periproct exhibiting nodular appearance in juvenile specimen. (f) Periproct exhibiting elongated appearance in juvenile specimen. (g) Periproct prolapsed in adult specimen. (h) In situ view of elongated periproct in juvenile specimen. (i) In situ view of nodular appearance of periproct in juvenile specimen. (j) Enlarged view of (i). (k) Needle mark artifact at the small intestine in juvenile specimen. (I) Enlarged view of (k). (m) Needle puncture artifact at the small intestine near esophagus of juvenile specimen. (n) Another juvenile specimen showing a needle puncture artifact at the small intestine near esophagus. (o) Tissues extracted view for the needle puncture artifact at the small intestine near esophagus of juvenile specimen. (p) Enlarged view of (o). (q) Enlarged hole possibly occurred following multiple needle punctures in an adult specimen. (r) High-magnification view and different angle of (q). (s) Black spots found at mesenteries of the esophagus within dashed area. (t) Enlarged view of (s) showing black spots. Black arrow = erosion; Esoph = esophagus; Go = gonad; LI = large intestine; Rect = rectum; SI = small intestine; White arrow = possible needle puncture mark artifact; White arrow head = nodule; White dashed arrow = black spots. 


\section{Materials Used}

- $100 \%$ formalin (37\% formaldehyde)

- Natural seawater $(35 \%)$

- $0.5 \mathrm{M}$ ethylenediaminetetraacetic acid disodium salt dehydrate $\left(\right.$ EDTA $\left.\mathrm{C}_{10} \mathrm{H}_{14} \mathrm{~N}_{2} \mathrm{Na}_{2} \mathrm{O}_{8} \cdot 2 \mathrm{H}_{2} \mathrm{O} ; \mathrm{MW}=372.24 \mathrm{~g}\right)$

- Ethanol (50\%, 70\%, 80\%, 95\%, and 100\%)

- Wide-mouth plastic container and lids $(250 \mathrm{~mL}$ and $500 \mathrm{~mL})$

- Scissors

- Forceps

- Scalpels

- Vials

- Digital single-lens reflex camera with macro lens

- Close-up speed light system

- Copy-stand light system for close-up photography

- Dissecting microscope (with attached digital camera)

- Light microscope (with attached digital camera)

\section{Processing}

After fixation, followed by decalcification, histology processing will follow routine methods (Luna 1968). The embedding orientation needs to be considered for some tissues, such as the Aristotle's lantern, where it is desirable to section the tissue longitudinally. The test should also be sectioned along a longitudinal axis so that the external and internal sides can be visible in a two-dimensional plane on a sectioned slide. Mayer's hematoxylin and eosin (H\&E) is an ideal stain to survey the tissue sections. After initial observations on H\&E-stained slides, extra sectioned slides can be stained if needed to identify specific features with special stains, e.g., periodic acid-Schiff (PAS; mucopolysaccharides [mucus, glycogen, or cellulose]), Giemsa (foreign organisms, in general), Gram (differentiates gram-negative and gram-positive bacteria), and Thionin (DNA).

Tissues can also be prepared with JB-4 (glycol methacrylate) embedding medium (Quintero-Hunter et al. 1991). Generally, this method produces higher resolution and better-quality sections than paraffin processing and is beneficial for photomicrography, especially to discern fine tissue structures. A drawback of using the JB- 4 medium is that the sectioned area is relatively small compared to the size of the section produced by paraffin embedding (i.e., the size of the mold used for JB-4 embedding is smaller than that used for paraffin). Sectioned slides processed in JB-4 medium also have limited staining capabilities, especially the application of immunostains and molecular-related reactions.

\section{Normal Microscopic Anatomy INTEGUMENTARY SYSTEM}

The test (Figures H1a-b, e) is composed of an epidermis and ossicles (calcareous trabeculae) that are magnesium-rich calcium carbonate. Decalcification during histology processing removes this mineral and leaves holes in the section. The basthiepithelial nerve plexus is composed of nerve fibers that innervate the epithelial cells and lie under the epidermis (Figures Hla-b, e-f, h-i). Pigmented cells with iridophores and chromatophores are found both outside and inside on the test.

The ossified appendages consist of spines, pedicellariae, sphaeridia, and tendons. The spine is a hollow cylinder at the center core. Spines (Figures Hla, e, g, j-p) are classified as primary, secondary, or miliary. Pedicellariae (Figure H1c) consist of a head, a neck, and a stalk region. The pedicellariae function in defense, feeding, and cleaning, with the valve movement regulated by abductor, adductor, and flexor muscles.

Iridophores are characteristic features of Diadema species that are embedded in epidermal tissue at the base of spines. 

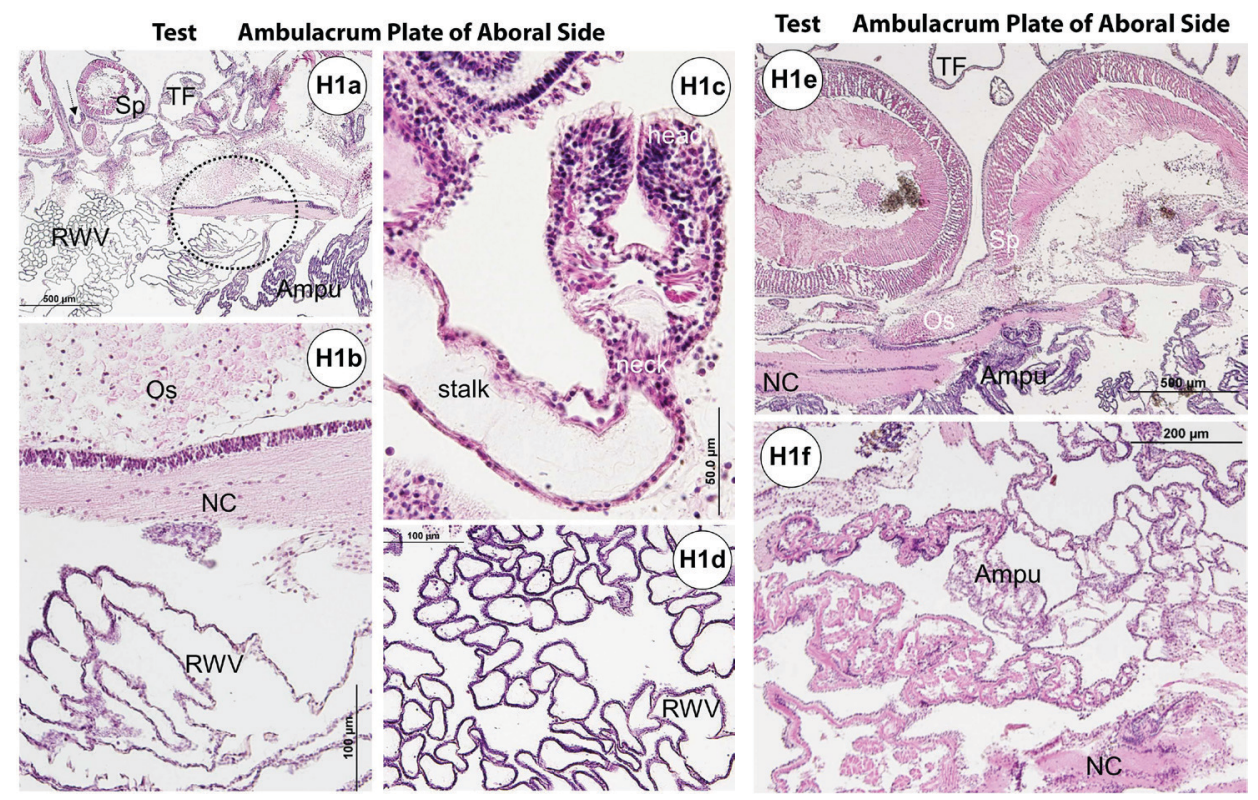

Test
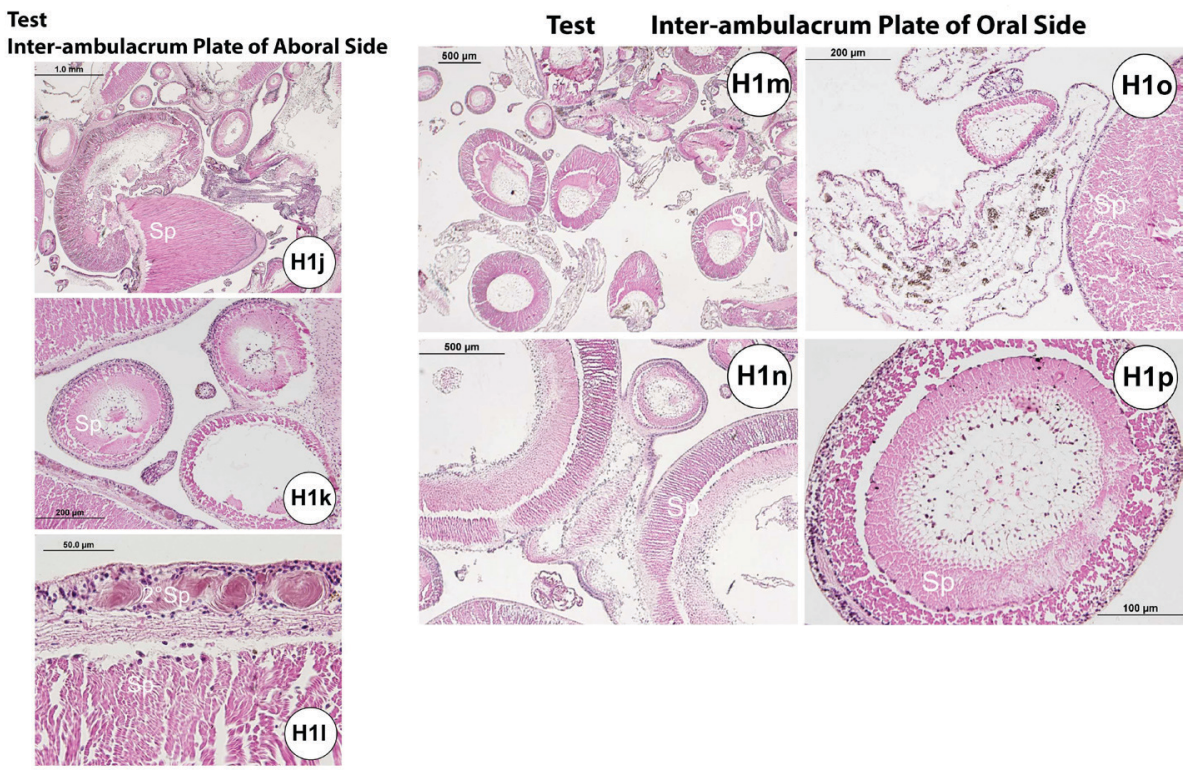

Figure H1. Integumentary system. (a) Test ambulacrum of the aboral surface area at low-power magnification view. (b) Circled area of (a) is magnified showing the test ossicle, nerve cord, and radial water vessel. (c) High-power magnification view of the pedicellaria with head, neck, and stalk segments. (d) High-power magnification view of the radial water vessel. (e) Test ambulacrum of the aboral side showing the tube foot, cross and longitudinally sectioned base of the spine (tubercle), ossicle, nerve cord, and ampullae. (f) High-power magnification view of the ampullae and piece of nerve cord shown. ( $g-i)$ Test ambulacrum of oral surface with the high-power magnification view of nerve cord in dashed circle of $(\mathrm{h})$ is shown in (i). ( $\mathrm{j}-\mathrm{l})$ Test interambulacrum of aboral surface. $(\mathrm{m}-\mathrm{p})$ Test interambulacrum of the oral surface. Ampu $=$ ampullae; $\mathrm{NC}=$ nerve cord; Os = ossicle; RWV = radial water vessel; $\mathrm{Sp}=$ spine; TF = tube feet. Figures $\mathrm{H} 1$ to H10: Photomicrographs of $4 \mu \mathrm{m}$ section of paraffin embedded Diadema antillarum tissues (formalin fixed, followed by decalcification with EDTA) stained with hematoxylin and eosin, except that inset of Figure $\mathrm{H} 8 \mathrm{c}$ stained with Giemsa, Figure H8f stained with Gram, and Figures H10b and d stained with thionin. Also note for exception that the Figures $\mathrm{H} 10 \mathrm{e}-\mathrm{h}$ were embedded with JB-4 plastic resin medium. Most photographs taken for the adult specimens, unless clearly noted as juvenile.

\section{WATER VASCULAR SYSTEM}

The madreporite (Figures H2a-d) connects to the stone canal. Just above Aristotle's lantern, the stone canal attaches to and supplies fluid to the ring canal that circles the esophagus as it emerges from the lantern. At five places around the ring canal (at the positions of the ambulacral plates), a radial canal originates and extends along the outer edge of Aristotle's lantern. At the base of Aristotle's lantern, after supplying fluid to the buccal podia, the radial canal divides into two canals, which travel in a parallel fashion along the inner surface of the ambulacral plate. From these twin radial canals, lateral canals diverge to supply fluid to each of the ampulla of the tube feet. The lateral water vessel extends to the ampulla (Figures $\mathrm{H} 2 \mathrm{e}-\mathrm{h}$ ) through a valve. Each radial water canal ends in a terminal tentacle on the aboral surface of the madreporite. 


\section{Water Vascular System}

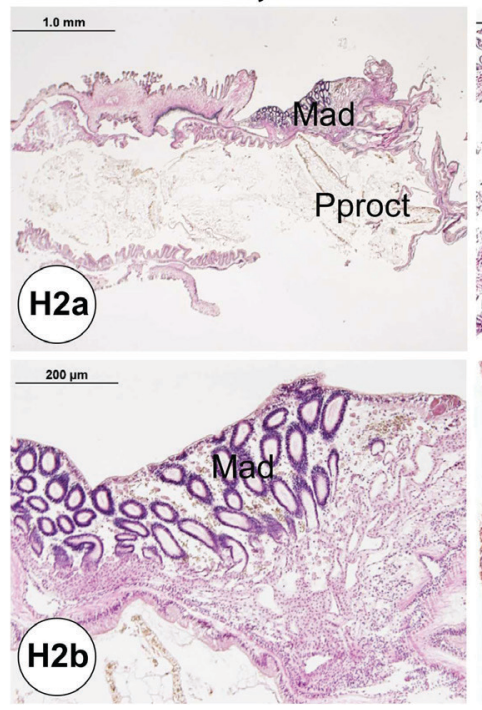

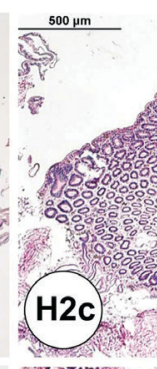
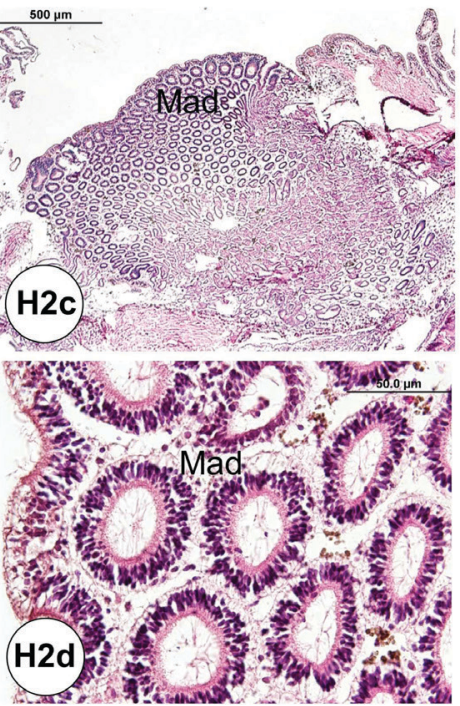

\section{Water Vascular System}
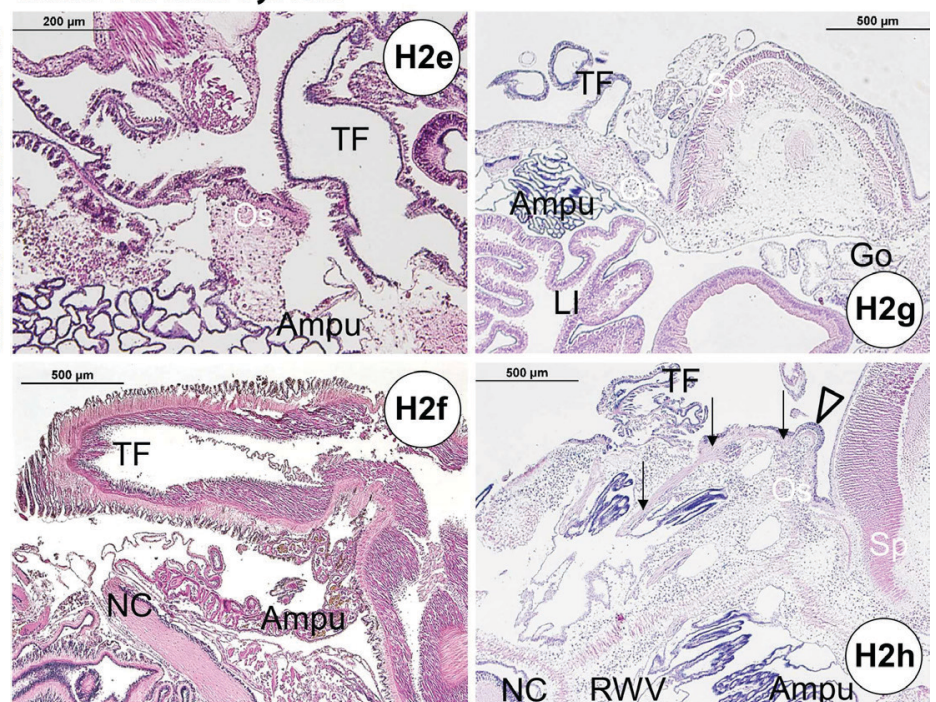

Figure H2. Water vascular system. (a) Longitudinal section of adult specimen's aboral area, periproct, and madreporite. (b) Moderate-power magnification of (a) showing the madreporite. (c) Tangential section of the adult specimen's madreporite. (d) High-power magnification view of (c) showing the madreporite. (e) Longitudinal section of adult's test ambulacral plate showing the arrangement of the tube foot, test ossicle, and ampullae. (f) Tangential section of adult's tube foot, ampullae, and piece of nerve cord shown. (g) Longitudinal section of juvenile specimen's test showing the arrangement of the tube foot, test ossicle, and ampullae. (h) Tangential section of juvenile specimen's test showing the water vascular system; the relationship to the tube foot, tubes within the ossicle connecting to the ampullae and radial water vessel. Note that sphaeridia shown with the surrounding nerve ring in this photomicrograph. Ampu = ampullae; Arrow = nerve ring; Arrow head = sphaeridia; Go = gonad; $\mathrm{Mad}$ = madreporite; $\mathrm{NC}=$ nerve cord; $\mathrm{Os}=$ ossicle; Pproct = periproct; $\mathrm{RWV}=$ radial water vessel; $\mathrm{TF}=$ tube feet.

\section{HEMAL SYSTEM}

Four types of coelomocytes are present (phagocyte, red spherule [red coelomocyte], colorless spherule [white coelomocyte], and vibratile cell) in the coelomic spaces and hemal vessels. The most abundant coelomocyte, the phagocyte, engulfs foreign materials. The red and colorless spherule cells are spherical, possess eccentric nuclei, and become amoeboid when contacting substrate. The red spherule cells contain red naphthoquinone pigment (echinochrome) (McClendon 1912). Vibratile cells (positive to the PAS stain) are the second most abundant cell type.

The axial complex (Figures $\mathrm{H} 3 \mathrm{a}-\mathrm{c}$ ) is composed of the head process (aboral diverticulum) and the axial organ, which are connected by the axial duct. Especially in the adult specimens, the axial organ contains abundant melanin pigments (Figures H3a-c). Tiedemann's bodies, located in the Aristotle's lantern (Figures H3d-e), are structurally similar to the axial organ, but their function is not well understood (Cavey and Märkel 1994). They may function as hematopoietic or lymphoid organs as in their vertebrate counterparts.

\section{GASTROINTESTINAL SYSTEM}

\section{i. Aristotle's lantern}

The mouth and pharynx contain mucus cells in the epithelial layer and are located in the central core of the Aristotle's lantern (Figures H4a-b). The interpyramidal muscle (Figures H4b-d) connects the pyramid (jaw tissue) and rotulae via ligament and collagenous fibers (Figure H4d).

Tiedemann's bodies are found on the ring canal and derived from the lantern coelom (see above hemal system). Polian bodies (or polian vesicles; Figures H3f, H4b) are also attached to the ring canal and are close to the Tiedemann's bodies (Figures H3d, H4b). The polian body's function is unknown, but it may function as a fluid reservoir. These two small organs tend to be hard to see grossly, unless the Aristotle's lantern is extracted carefully using a dissecting microscope. 

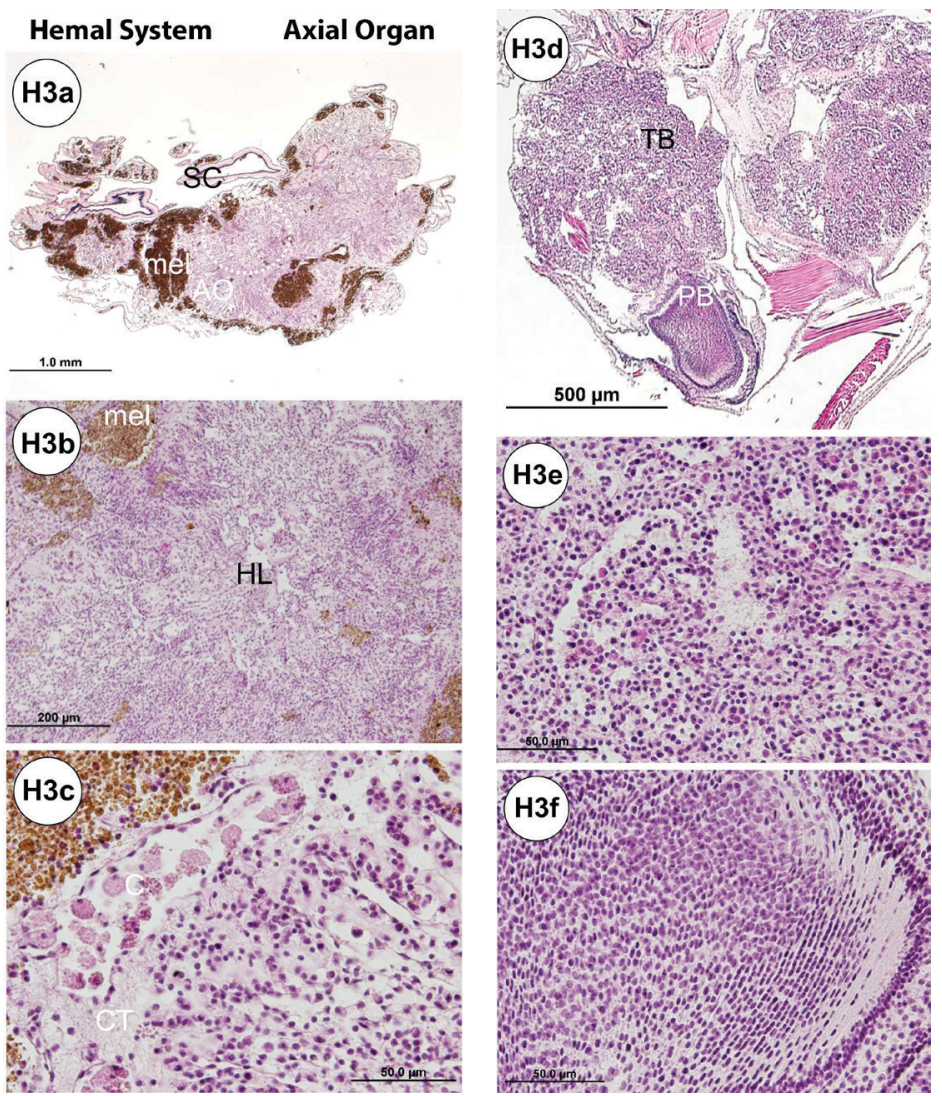

Figure H3. Hemal system. (a) Low-power magnification view of the adult specimen of axial organ possessing abundant melanin pigments, and surrounding stone canals. (b) Moderate-power magnification of the axial organ of dashed circled area of (a) with hemal lacunae. (c) High-power magnification view of the axial organ showing produced coelomocytes in the hemal vessel. (d) Tiedermann's body and Polian body located in the Aristotle's Lantern. (e) Highpower magnification view of Tiedermann's body that shows similar tissue structure to the axial organ. (f) High-power magnification view of Polian body. $\mathrm{AO}=$ Axial organ; $\mathrm{C}=$ coelomocytes; $\mathrm{CT}=$ connective tissue; $\mathrm{HL}$ = hemal lacuna; mel = melanin pigments; $\mathrm{PB}=$ Polian body; $\mathrm{SC}=$ stone canal; TB = Tiedermann's body.

\section{Aristotle's Lantern}

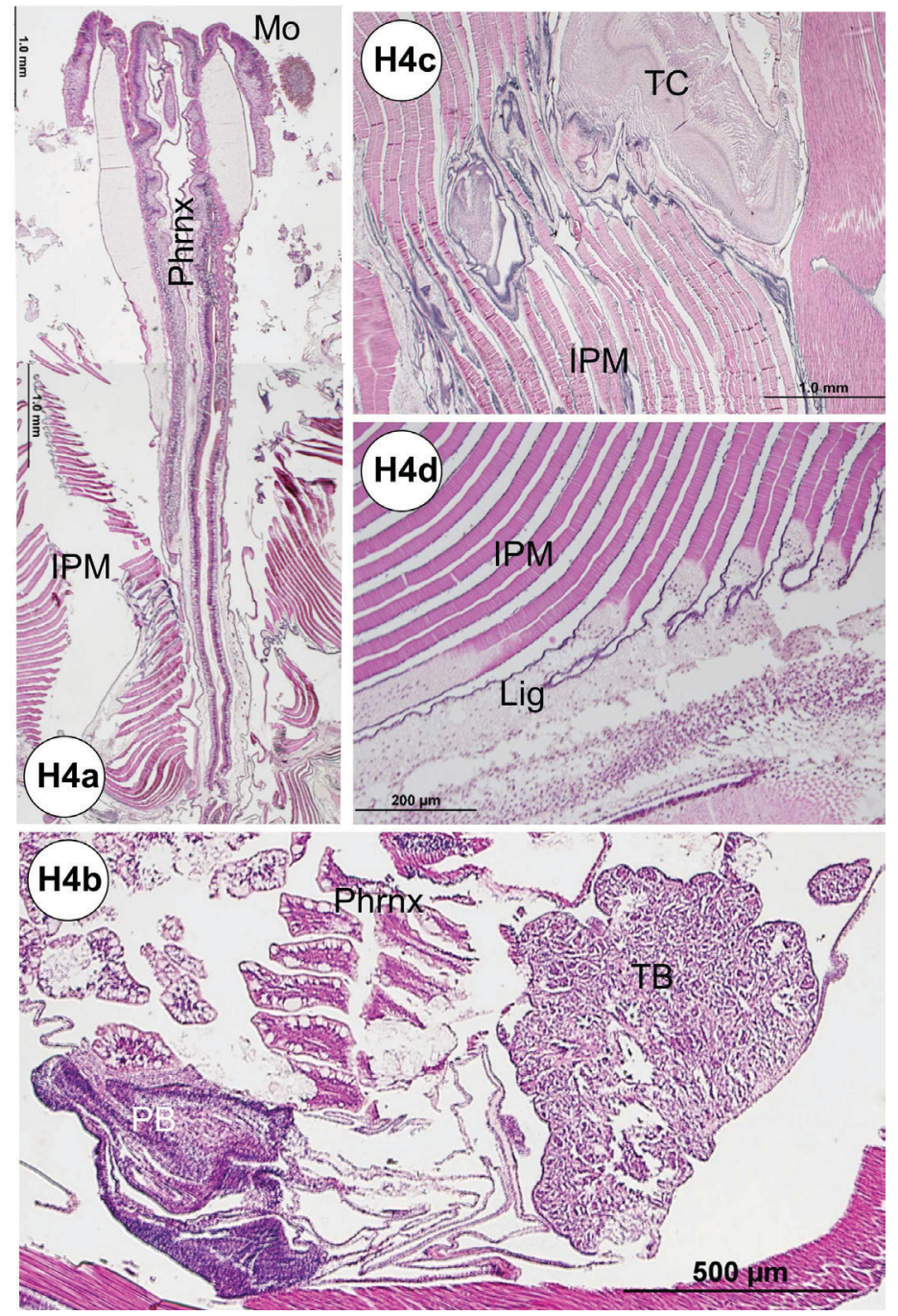

Figure H4. Aristotle's lantern and associated organs. (a) Longitudinal section of the mouth and proximal to distal distance of the pharynx and surrounding interpyramidal muscle. (b) Longitudinal section of the pharynx, Tiedermann's body, and Polian body shown. (c) Longitudinal section of the interpyramidal muscle attached to the tooth coelom. (d) Interpyramidal muscle shown at the connection to the ligament. IPM = interpyramidal muscle; $\mathrm{Lig}=$ ligament; $\mathrm{Mo}=$ mouth; PB = Polian body; Phrnx = pharynx; TB = Tiedermann's body; $\mathrm{TC}=$ tooth coelom. 


\section{ii. Alimentary tract}

Following the mouth and pharynx (Figures H5a-b), the esophagus (Figures H5c-f) also possesses microvilli of glandular enterocytes and has numerous mucus cells. The mucus cells are fewer in number in the small intestine (or "stomach";

Figures H5g-i) compared to the epithelial layer, and they are largely absent between the large intestine and rectum, where the microvilli of the nonglandular enterocytes increase. The microvilli of the small intestine tend to be longer than those of the large intestine (Figures H5j-l). In histological sections of the small intestine, curled or rounded-up pieces of tissue are occasionally found. The small intestine has a thicker diameter wall than the large intestine. The rectum (Figures $\mathrm{H} 5 \mathrm{~m}-\mathrm{O}$ ) and periproct (Figures $\mathrm{H} 5 \mathrm{p}-\mathrm{q}$ ) are located at the posterior end of the gastrointestinal tract.
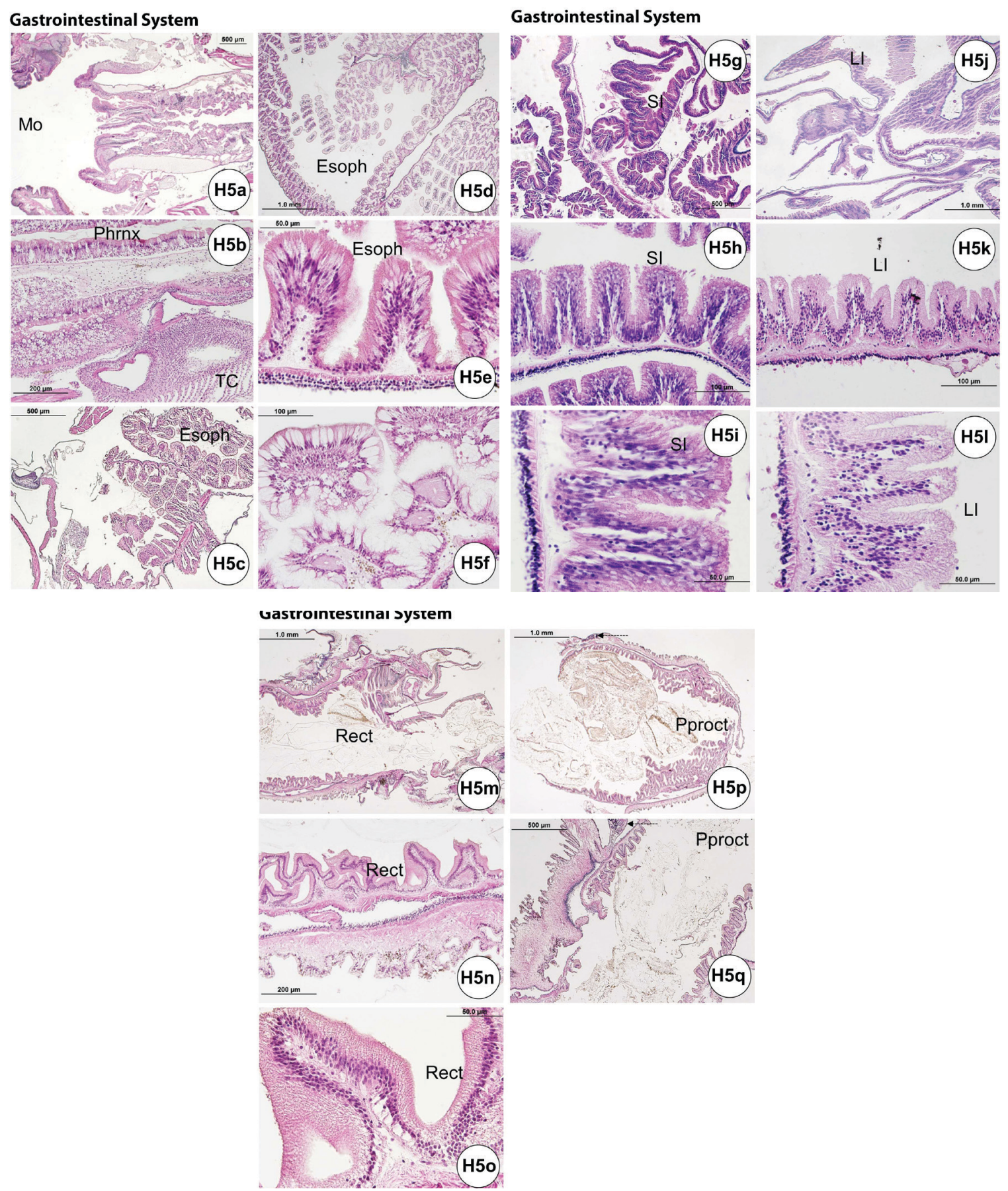

Figure H5. Gastrointestinal system. (a) Mouth. (b) Pharynx, vertically run through the Aristotle's Lantern. (c) Junction of esophagus and pharynx at the Aristotle's Lantern (pharynx not shown in this photograph). (d) Cross-section of the esophagus. (e) Longitudinal section of the esophagus. (f) Esophagus abundant with mucus; cells line the lumen of the esophagus. ( $g-i)$ Small intestine with less abundant mucus cells. ( $j-l$ ) The nonglandular enterocytes line the large intestine. $(\mathrm{m}-\mathrm{o})$ Rectum. $(\mathrm{p}$ and $\mathrm{q})$ Aboral area showing periproct or anus. Arrow $=$ madreporite; Esoph $=$ esophagus; $\mathrm{LI}=$ large intestine; $\mathrm{Mo}=$ mouth; Phrnx = pharynx; Pproct = periproct; Rect = rectum; $\mathrm{SI}=$ small intestine; $\mathrm{TC}=$ tooth coelom . 


\section{REPRODUCTIVE SYSTEM}

Histological processing of the gonads allows for confirmation of sex. It may also be useful in staging urchin maturity (e.g., adult, juvenile, or larva). For example, a female collected in spring (March) exhibited some degenerative changes in the ovary and phagocytosing necrotic or atretic oocytes, indicated by the occurrence of brown pigmented cells (Figures H6a-b). Some urchins collected during the spring season also exhibited atretic oocytes (Figures H6c-d). However, male urchins collected in April had fully mature testes with spermatids (Figures H6e-f). Nutritive phagocytes (i.e., accessory cells) are commonly found, especially in adult specimens (Figure H6b). Their abundance is likely influenced by season.

Juveniles collected in September had immature gonads (Figures H6g-h). Examples are shown in Figure H6g (ovary) and Figure H6h (testis). Sex may be difficult to determine using histological assay if the gonadal tissue is exceptionally immature in the urchins.

\section{Reproductive System}
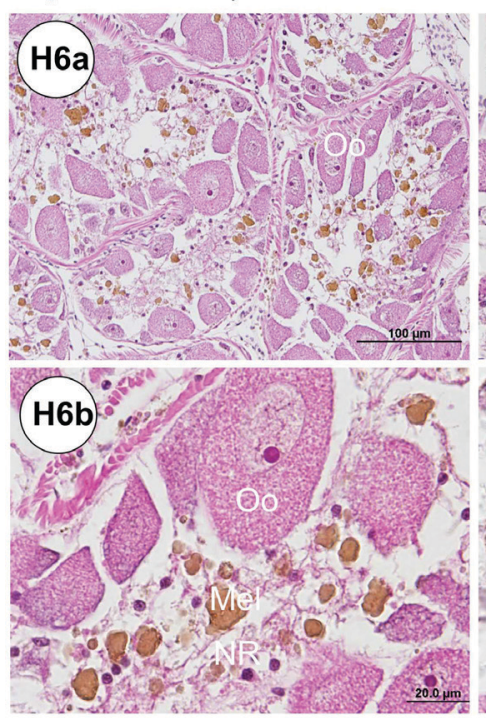
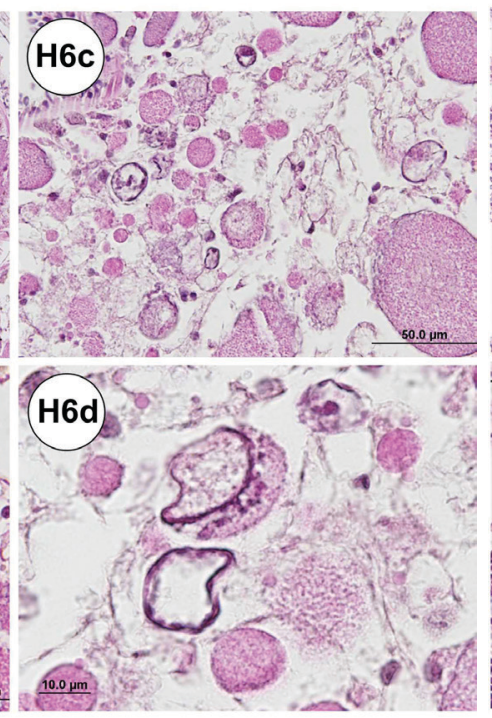

\section{Reproductive System}

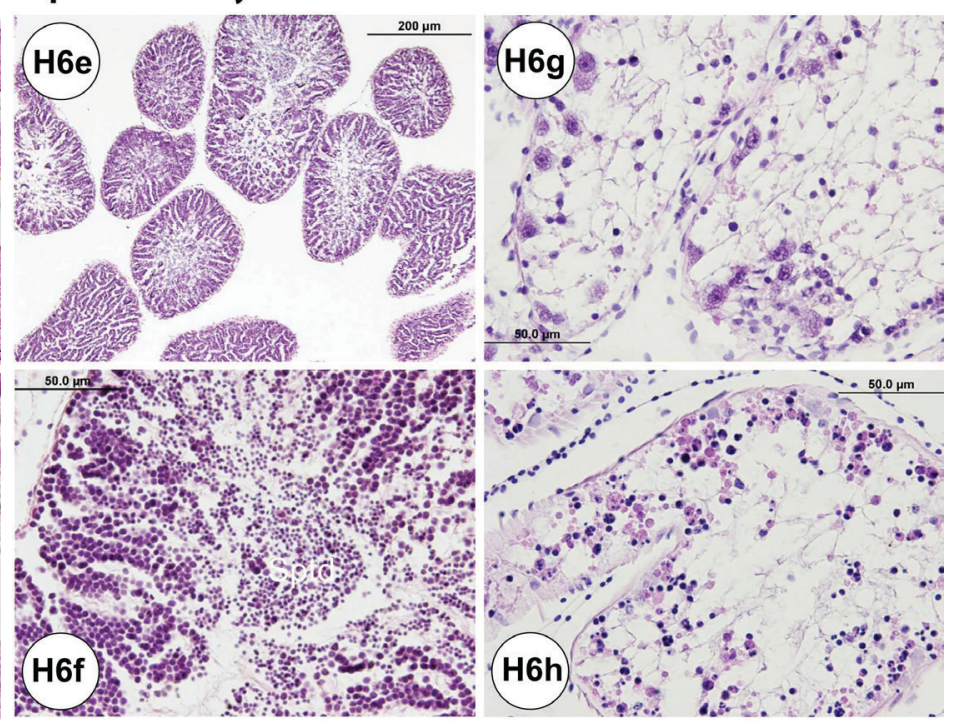

Figure H6. Reproductive system. (a-b) Adult ovary specimen collected in spring season (March), exhibiting some degenerative changes and phagocytosis indicated with occurrence of brown pigmented cells. (c-d) Another example of adult ovary specimen collected in spring, exhibiting degenerative changes and atresia. (e-f) Adult testis specimen collected in spring season (April). (g) Juvenile immature ovary collected in fall season (September). (h) Juvenile immature testis collected in fall season (September). Mel = melanin pigments; NR = nutritive phagocytes; Oo = oocytes; Sptd $=$ spermatids.

\section{RESPIRATORY SYSTEM}

The primary function of the gills (Figure H7a) is thought to be excretory rather than respiratory. Necrotic coelomocytes and other waste materials are phagocytosed in the gills (Figure H7b) for their eventual elimination over the gill epithelia (Carvey and Markel 1994). Gills are outpocketings of the peripharyngeal (lantern) coelom. During our investigations, needle-like or spine-shaped objects were usually present in the lumen of the hemal vessels, and they were always phagocytosed and associated with the presence of melanin pigments (Figure H7c). It was common to find melanized hemocytes in the lumen of the hemal vessel.

The major respiratory function occurs at the water vascular system in the tube feet and ampullae. Intake-fluid circulation occurs between tube foot and ampulla (myoepithelial septum, channels, and myoepithelial cylinder separated by podial septum), creating afferent and efferent currents (Carvey and Markel 1994).

\section{NEURAL SYSTEM}

The radial nerve cord is located at the outermost layer of the test (Figures H1a-b, e-f, h-i; H2f, h). It is composed of ectoneural nerve tissue found in the epidermis, and the hyponeural nerve tissue underneath the dermis. The nerve ring surrounds the mouth. 


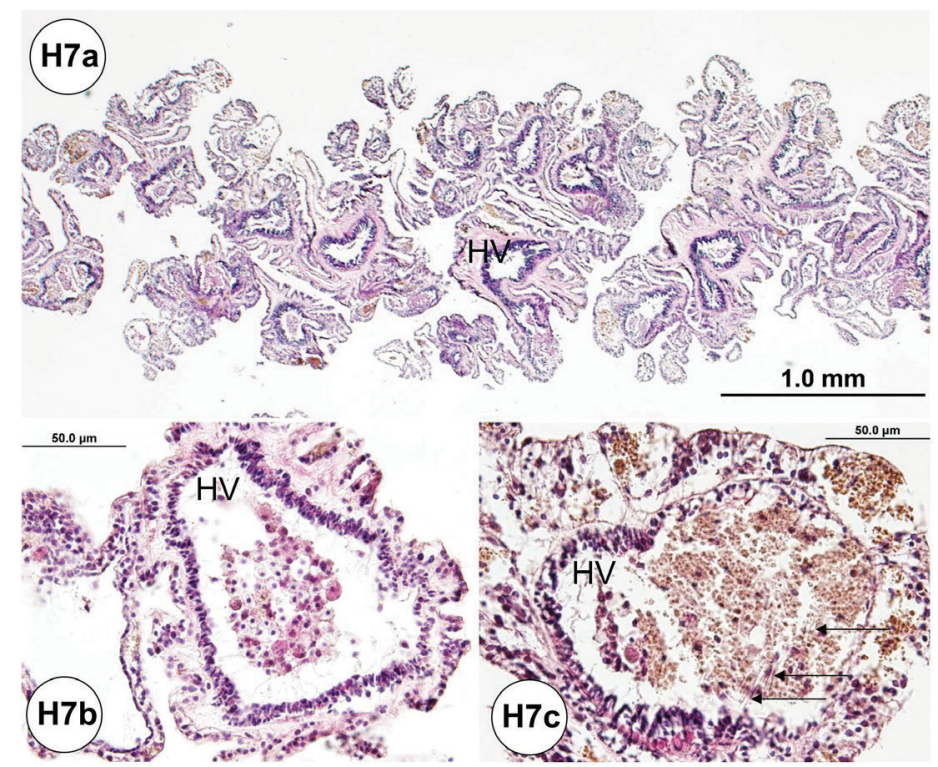

Figure H7. The gill. (a) Low-power magnification view of the gill. (b) Aggregates of coelomocytes found in the lumen of hemal vessel. (c) Brown pigments (i.e., melanized hemocytes) surround needle-like objects (arrows) exhibiting granuloma-like appearance in the lumen of hemal vessels. $\mathrm{HV}=$ hemal vessel.

\section{SENSE ORGAN}

Five pairs of modified tube feet (buccal podium), located in a circular field of the peristomial membrane, are considered chemoreceptors, although their function is not well understood.

Multiple sphaeridia (Figure H2h) located at the ambulacrum near the tube foot are considered as sensory appendages for maintaining equilibrium (georeception). Because the sphaeridium is small (approximately $350 \mu \mathrm{m}$ in length), locating it histologically is sometimes fortuitous.

The ocular plate is located on the aboral plate of the gonadal and interambulacral plates.

\section{Disease and Remarkable Abnormal Conditions}

Needle-like or spine-shaped objects (or spicules) are associated with a host cellular response (Figures H8a-b) which is indicated by the phagocytosis of presumed foreign objects. These are likely ejected through an excretory process. These needle-like objects were present in the hemal vessels of the gill, aboral or oral sides of the test ambulacra, and the large intestine and gonad.

Basophilic cellular aggregates (Figures H8a, c) may be seen within the hemal vessels of the gill, and on the aboral or oral sides of the test ambulacra.

Brown pigments (Figures 8a-b) may be found in the gill tissue of urchins at all locations examined and appear quite common as the gills have an excretory function rather than respiratory (see above: normal microscopic anatomy). Brown pigments may be found throughout the tissues, but prominently in the esophagus, small intestine, large intestine, and gonad.

Though rare, bacterial colonies (Figures H8d-f) were detected on the oral hemisphere of the test in some specimens. The bacteria were gram-negative, short rods (Figure H8f), and appeared to be associated with nerve fiber cells (Figure H8d) located in the test tissues.

Ciliates of various taxa (Figure H9) can be found in the gill, on the dermal tissue of the test, esophagus, small intestine, large intestine, rectum, and gonad. 
Amoebae or similar organisms may be detected histologically in the small intestine. The organisms were commonly associated with the luminal surface of the epithelial cell lining of the small intestine (Figures H10a-d), including areas that exhibited epithelial erosion (Figures H10e-h). The amoeba pseudopods (or filopods) stained lightly eosinophilic (Figures H10f-h). Possible food vacuoles in the amoebae were stained strongly eosinophilic in slides prepared with JB-4 embedded plastic resin (Figures $\mathrm{H} 10 \mathrm{f}-\mathrm{h}$ ).

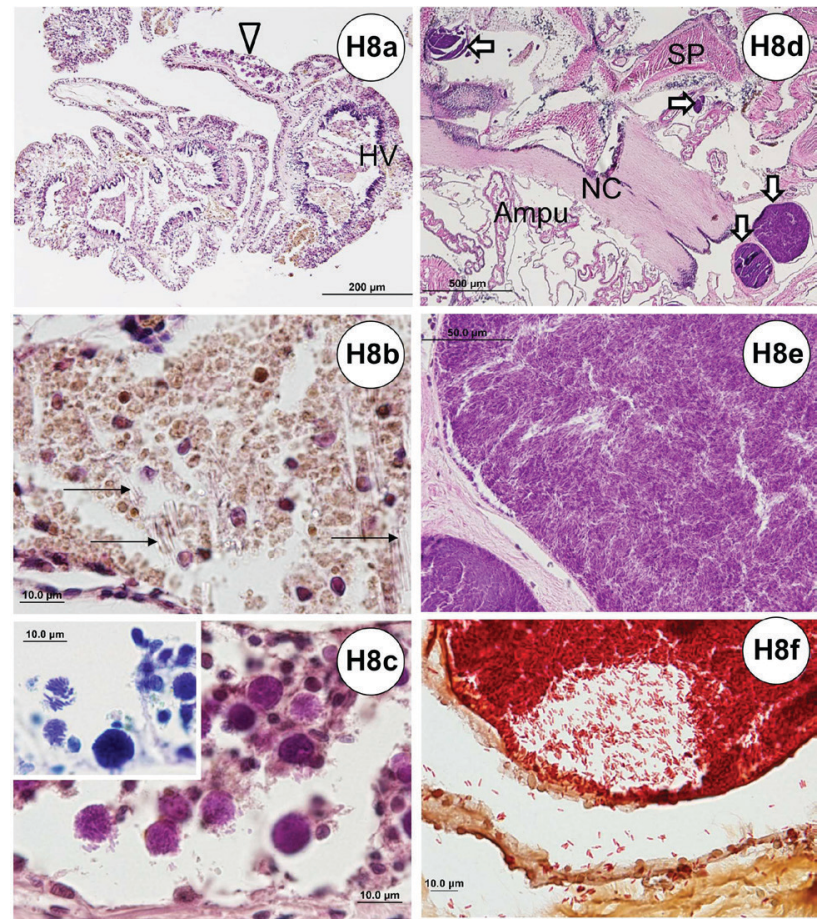

Figure H8. Histopathological section of the gill and test. (a) Tangential section of gill. (b) Higher magnification of the hemal vessel of the gill showing needle-like structures (spicule) associated with coelomocyte aggregates. (c) High-power magnification of (a) showing basophilic cellular aggregates (sphere) in hemal vessel. Inset shows Giemsa stain. (d) Bacterial colonies found at the oral side of the test, internally. (e) Bacterial colonies with high-power magnification of (d). (f) Gram-negative, short rod bacteria demonstrated with Gram stain. Ampu = ampullae; Arrows, thin = needle-like objects; Arrow, thick hollow = bacterial colonies; Arrow head, hollow = basophilic cellular aggregates; $\mathrm{HV}=$ hemal vessel; $\mathrm{NC}=$ nerve cord; $\mathrm{Sp}=$ spine.

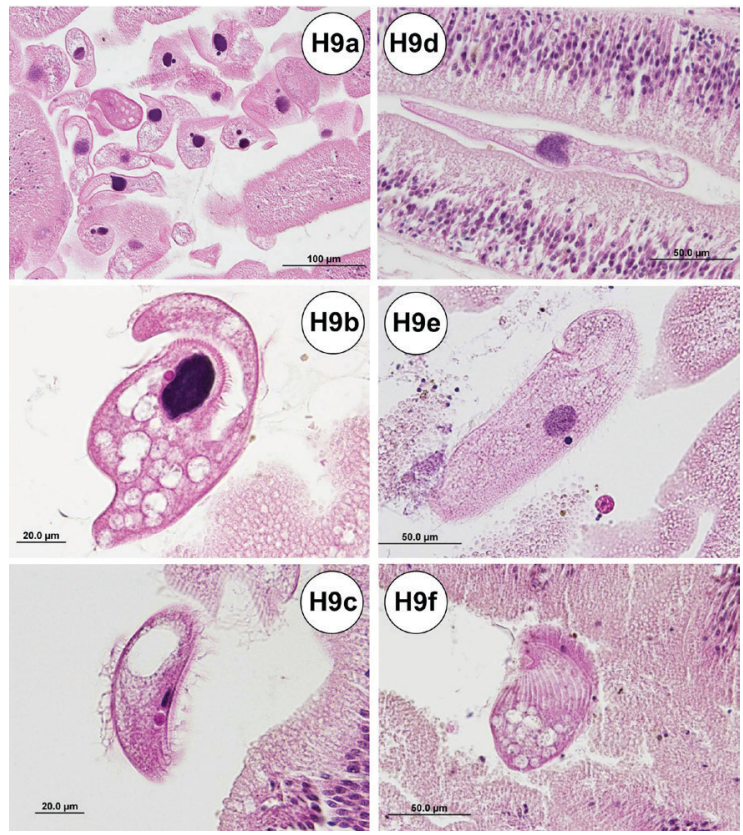

Figure H9. Histopathological section of the large intestine showing various ciliates. (a) Low-magnification overview of several specimens. (b) Parametopus circumlabens (tentative identification). (c) Biggaria echinometris (tentative identification). (d) Unidentified ciliate (likely different species from a, b, c). (e) Biggaria bermudense (tentative identification). (f) Paracyclidium rhabdotectum (tentative identification). 

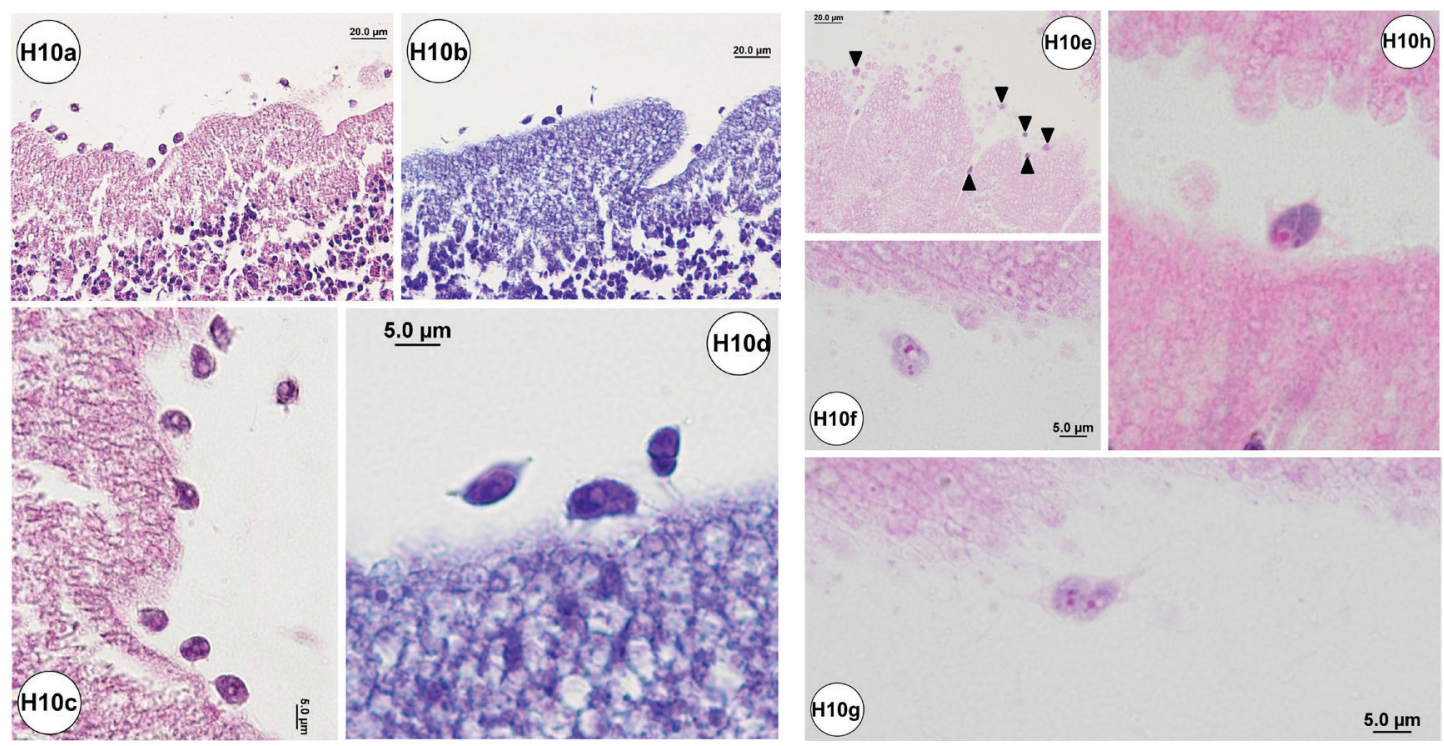

Figure H10. Histopathological section of the small intestine showing amoeba. (a) Cytoplasm of basophilic stained amoeba found at the surface of epithelial cell lining. (b) Same area of (a) stained with Thionin. (c) High-power magnification of (a). (d) High-power magnification of (b).

(e) Moderate-power magnification showing amoeba (arrow heads) and gut epithelial cell erosion. (f) High-power magnification of amoeba.

(g) High-power magnification view of an amoeba cell with pseudopod (lightly eosinophilic stained) and food vacuoles (strongly eosinophilic stained). (h) Another view of an amoeba using the highest power magnification possible by light microscopy (1.6x converter lens along with 100x objective lens used).

Oocytes were scattered only in samples collected during the fall season for the following tissues: gill, both outer surface and internal side of the test, esophagus, small intestine, large intestine, and rectum. 


\section{Parasitology}

\section{External Examination}

Sea urchins should be carefully examined for the presence of macroscopically visible fauna on the test or spines. Amphipods (Figure 21) have been observed attached to the spines of wild-caught animals. Although unlikely to pose a problem in free-living urchins, these organisms may have the potential to cause disease if undetected in aquaculture systems. These organisms are visible without magnification, but smaller epibionts will only be detected with examination by dissecting scope or head loop.

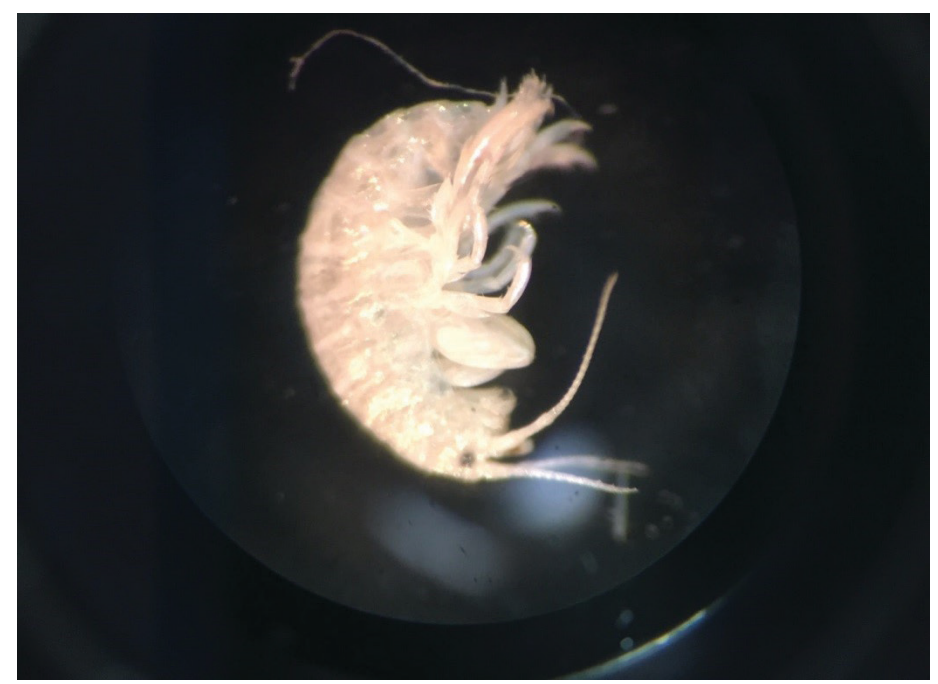

Figure 21. An amphipod found on the spines of two different wild D. antillarum collected from the Upper Keys in September 2015. The organism is believed to be in the genus Gamarus.

Credits: Patrick Baker, UF/IFAS

\section{Use of Wet Mounts}

Areas with visible external damage to the test should also be examined using a light microscope. This requires scraping the area of concern with a cover slip and placing any recovered tissue on a microscope slide with a drop of seawater. This procedure is a modification of the routine collection of external tissue biopsies as part of the clinical examination of fish and is an excellent method for detection of external protozoa and other microscopic flora (Noga 2010).

Direct examination of fresh fecal material with a light microscope is an effective method for assessing populations of intestinal protozoa (see Cytology section). Fecal balls can be collected directly from the animal or from the bottom of the holding tank (less desirable). A direct smear can be made using seawater, or sterile water of the same salinity. A thin smear of fecal material and seawater should be placed on a glass slide, covered with a cover slip, and then examined with a light microscope with lowered condenser. Wet mounts should be examined immediately after preparation as slides dry out quickly. Salt crystals, which form during the drying process, make interpretation of findings more difficult.

Protozoa are easiest to detect by their movement in the fresh material. They can be identified using morphologic characteristics. Four large ciliate taxa (Figures 22-24) were found with some regularity when examining wild-caught sea urchins from Florida. The presence of flagellates or amoeba-like organisms is more difficult to detect in fresh material. Stained specimens and histologic sections are more useful for detection of these smaller organisms.

Examples of the commonly observed ciliates in fresh preparations are shown (Figures 22-24).

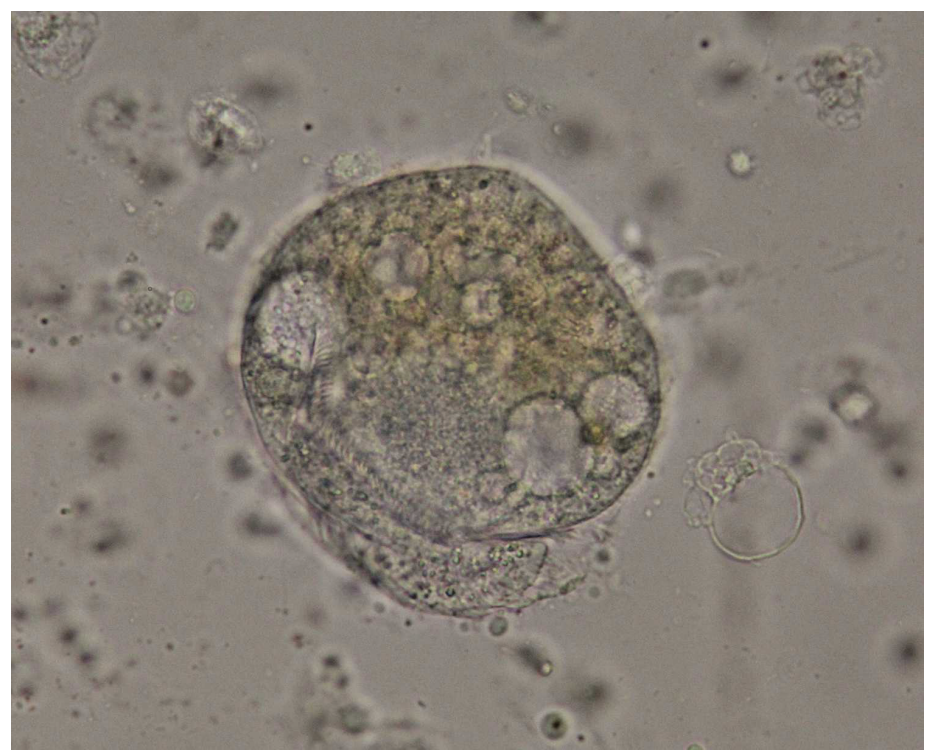

Figure 22. A common protozoan observed in fecal material of $D$. antillarum from the Florida Keys. This organism is believed to be Parametopus circumlabens (600x).

Credits: Deborah Pouder, UF/IFAS

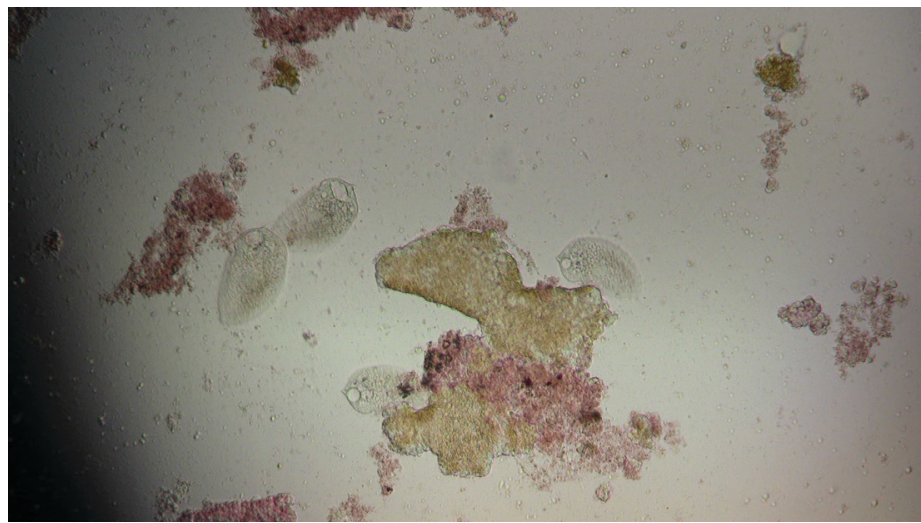

Figure 23. Large ciliates observed in fresh fecal smears from $D$. antillarum collected in the Florida Keys. This organism is likely Biggaria sp., possibly B. bermudense (200x).

Credits: Deborah Pouder, UF/IFAS 


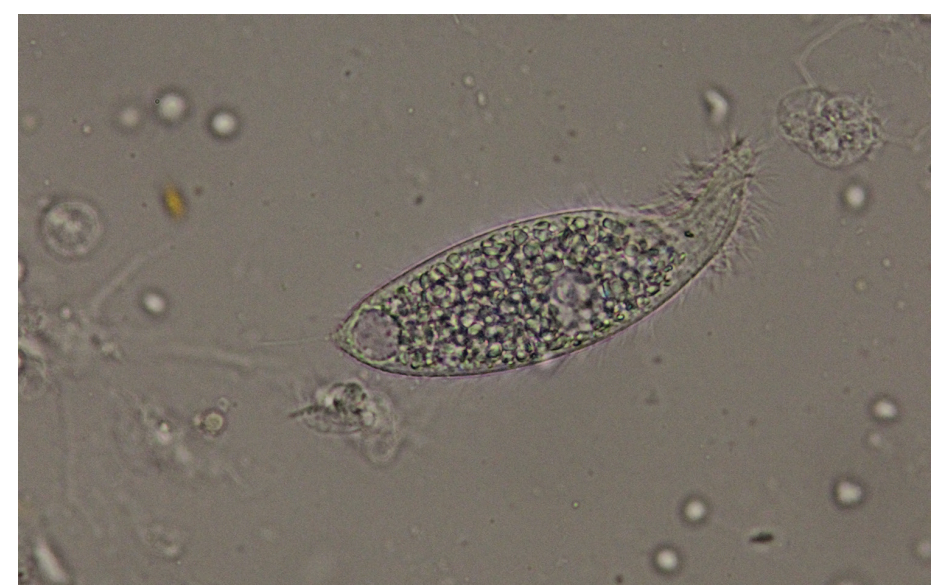

Figure 24. An elongated ciliate from fresh fecal material collected from $D$. antillarum from the Florida Keys. The organism may be Amphileptus punctatus (600x).

Credits: Deborah Pouder, UF/IFAS

\section{Cytology}

Fecal cytology can be assessed following preparation of direct fecal smears; however, the protozoa may be lysed. They appear to degenerate quickly when the slides dry, and are best observed in direct smears of fresh fecal material examined by wet mount, described above. Prepared slides should be examined immediately for best results. Examples of protozoa seen in stained dry mount fecal preparations are shown below (Figures 25 and 26).

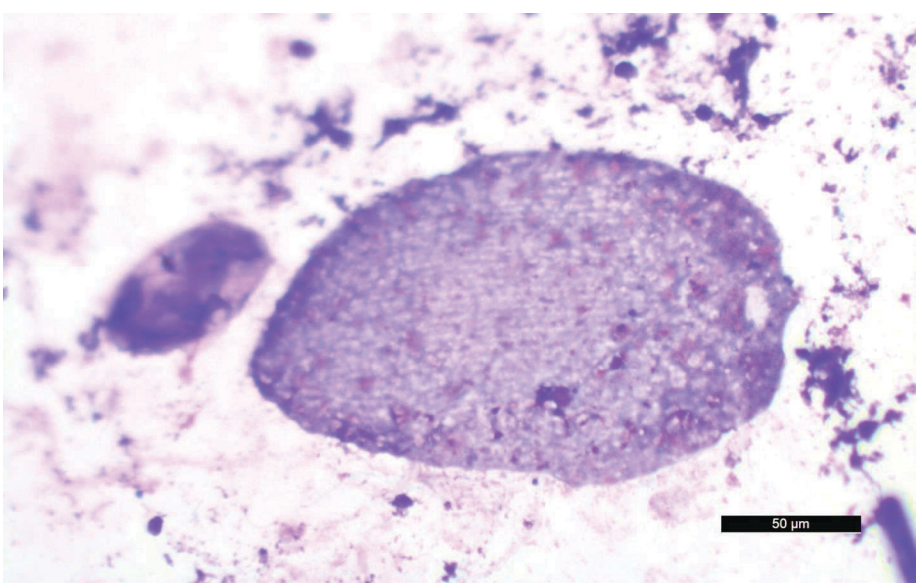

Figure 25. A large ciliate in a stained preparation from a fecal direct smear stained with Wright-Giemsa. The morphology of this organism is suggestive of Biggaria spp., possibly B. bermudense.

Credits: Nicole Stacy, UF College of Veterinary Medicine

Stained specimens were also useful for detection and characterization of diatoms (Figure 27), a common finding. Stacy et al. (2018) have published examples of plant material and diatoms found in fecal cytology from $D$. antillarum.

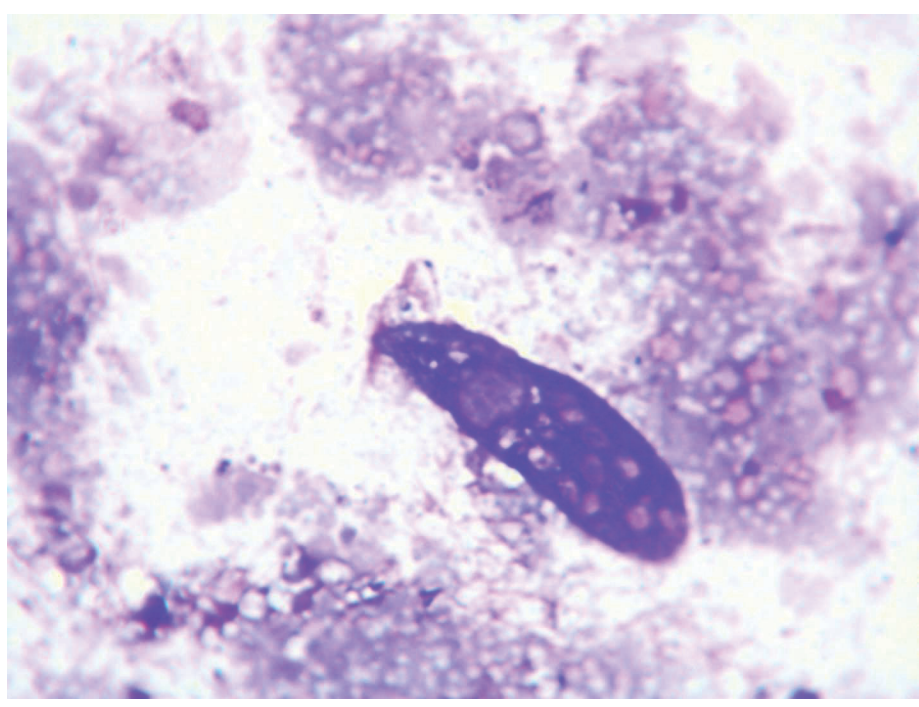

Figure 26. This elongated ciliate was readily identified in a fecal cytology specimen stained with Wright-Giemsa. The morphology of this organism is suggestive of Amphileptus punctatus.

Credits: Nicole Stacy, UF College of Veterinary Medicine

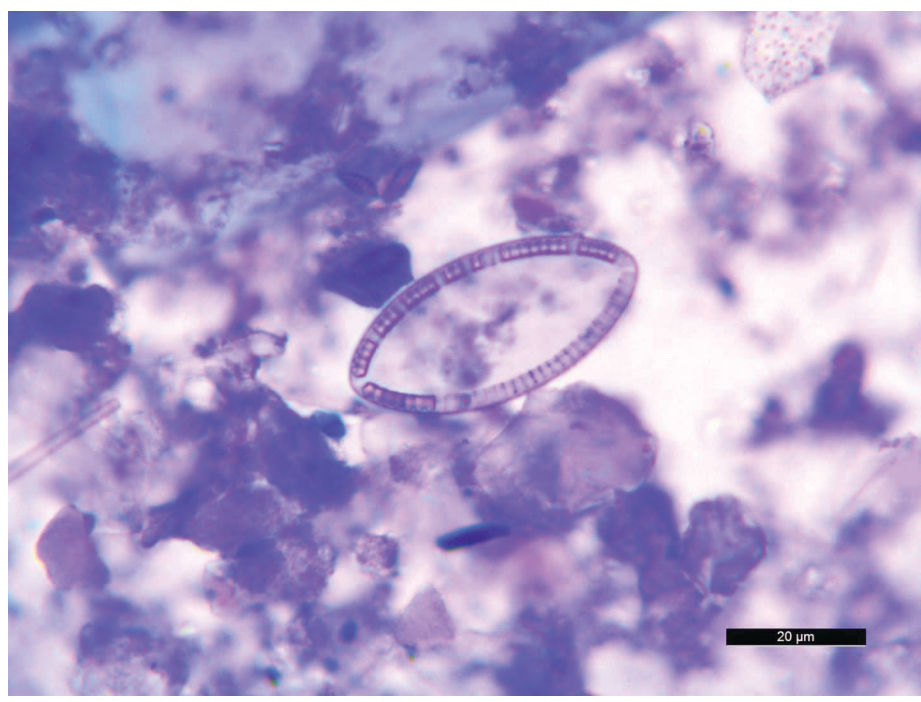

Figure 27. An example of a diatom observed in a Wright-Giemsastained fecal direct smear of $D$. antillarum collected in the Middle Keys in March 2015.

Credits: Nicole Stacy, UF College of Veterinary Medicine

\section{Use of Zn-PVA Preservative}

Fecal samples from wild-caught $D$. antillarum can be preserved in Zn-PVA fixative for later examination via trichrome stain. This technique is particularly useful for detection of amoeba in other species (Garcia and Bruckner 1993). This method is also effective in detecting amoeba, diatoms, and some protozoa in sea urchins. An example of a suspect amoebic trophozoite is shown below (Figure 28). 


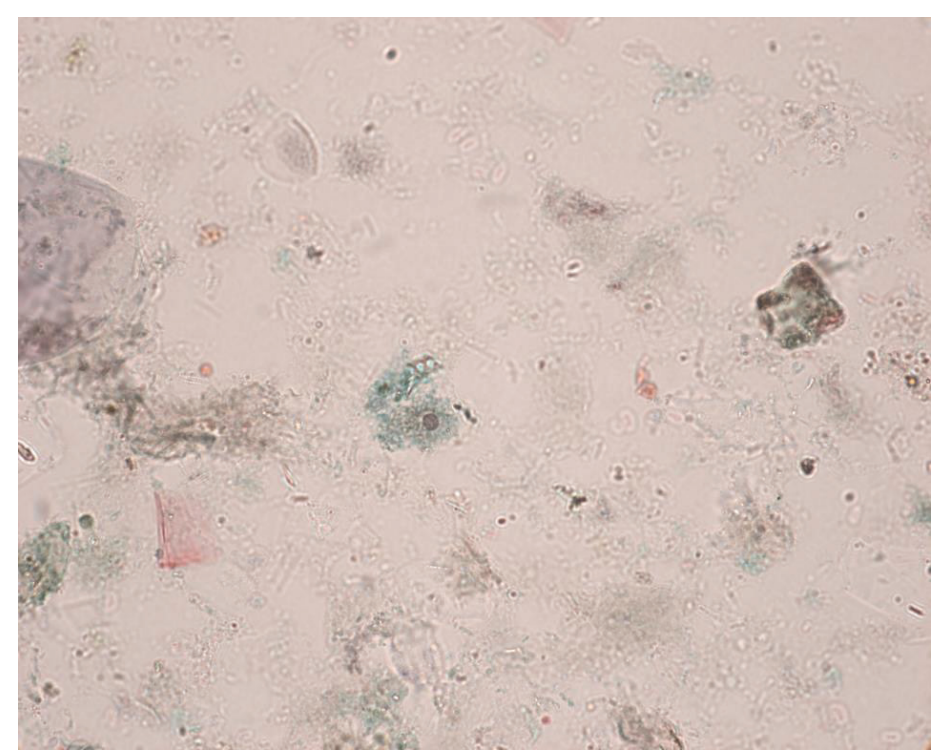

Figure 28. Suspect amoeba trophozoite from wild-caught $D$. antillarum from the Lower Keys. Fecal material was fixed in Zn-PVA and then stained with a trichrome stain (1000x).

Credits: Heather Walden, UF College of Veterinary Medicine

\section{Use of Histology to Detect Protozoa and Amoeba}

Histologic techniques and interpretation are described in detail above. Protozoa and amoeba are readily detected using standard techniques and staining. Examples are shown in Figures H9 and H10.

\section{Suggestions for Health Assessment and Release Criteria}

The Diadema health assessment team has developed suggestions for consideration in the development of release criteria for the species in Florida (Appendix 4). Suggestions include consideration of the behavioral profile (described as Category One behaviors above) and a more detailed evaluation (Category Two behavioral assessment and accompanying physical examination) of a subset (20\%) of the population being considered for release. Thorough diagnostic evaluations of sick or abnormal animals are essential, because little is understood about disease processes in this species. Culturists, biologists, and diagnosticians will have to continue to work together to gain a greater understanding of disease processes in these organisms.

\section{Acknowledgements}

The authors would like to acknowledge Noretta Perry, Yvonne Waters, Meredith Zahara, and Eli Bastian (FWC/ FWRI/Fish and Wildlife Health) for processing the paraffin and plastic embedded histological slides of sea urchin tissues. Kayla Ripple (UF/IFAS Program in Fisheries and Aquatic Sciences (Center for Conservation)), Melissa
Garnett (FWC/FWRI/Freshwater Fisheries Management/ Richloam Fish Hatchery), and Morgan Beaton (FWC/ FWRI/Marine Fisheries Research/Marathon, Keys Fisheries Research) assisted with necropsy and tissue collections. Patrick Baker (UF/IFAS Program in Fisheries and Aquatic Sciences) provided identification of amphipods found on the spines of wild-caught $D$. antillarum. Theresa Floyd (UF/IFAS Program in Fisheries and Aquatic Sciences) assisted with statistical analysis and manuscript preparation. Mark Flint (UF/IFAS Program in Fisheries and Aquatic Sciences (Center for Conservation)), Thierry Work (USGS-Hawaii), and John Than (Florida Aquarium) were active contributors to the 2014 workshop and provided substantial guidance in the development of diagnostic protocols. Lisa Gregg (FWC/Division of Marine Fisheries Management, Tallahassee) provided comment on the draft of release criteria developed for D. antillarum as part of this project.

The authors thank Dr. Josh Patterson (UF/IFAS) and Dr. Sally DeNotta (UF College of Veterinary Medicine) for review of this manuscript.

The project was supported by the Florida Fish and Wildlife Conservation Commission program, Florida's Wildlife Legacy initiative (State Wildlife Grants CFDA No. 15.634), and the United States Fish and Wildlife Service grants program, Marine Projects Grant Cycle 2013 T-37 (federal award No. T-F14AF00891).

\section{References}

Applegate, J. R., D. S. Dombrowski, L. S. Christian, M. P. Bayer, C. A. Harms, and G. A. Lewbart. 2016. "Tricaine methanesulfonate (MS-222) sedation and anesthesia in the purple-spined sea urchin (Arbacia punctulata)." J. Zoo Wildl. Med. 47(4): 1025-1033. https://doi. org/10.1638/2015-0288.1

Bak, R. P. M., M. J. E. Carpay, and E. D. de Ruyter Van Steveninck. 1984. "Densities of the sea urchin Diadema antillarum before and after mass mortalities on the coral reefs on Curacao." Mar. Ecology Prog. Ser. 17: 105-108. https://doi.org/10.3354/meps017105

Bauer, J. C. 1976. "Growth, aggregation and maturation in the echinoid, Diadema antillarum." Bull. Mar. Sci. 26(2): 273-277.

Bauer, J. C. and C. Agerter. 1987. "Isolation of bacteria pathogenic for the sea urchin Diadema antillarum (Echinodermata: Echinoidea)." Bull. Mar. Sci. 40: 161-165. 
Bauer, J. C., and C. J. Agerter. 1994. "Isolation of potentially pathogenic bacterial flora from tropical sea urchins in selected West Atlantic and East Pacific sites." Bull. Mar. Sci. 55: $142-150$.

Bauer, J. C., and C. M. Young. 2000. "Epidermal lesions and mortality caused by vibriosis in deep-sea Bahamian echinoids: a laboratory study." Dis. Aquat. Org. 39: 193-199. https://doi.org/10.3354/dao039193

Beck, G., R. Miller, and J. Ebersol. 2009. "Significance of immunological responses in the black-spined sea urchin, Diadema antillarum, to Caribbean-wide mass mortality." Proceedings of the 11 International Coral Reef Symposium (Ft. Lauderdale, FL): 221-225.

Beck, G., R. Miller, and J. Ebersol. 2014. "Mass mortality and slow recovery of Diadema antillarum: Could compromised immunity be a factor?" Mar. Biol. 161: 1001-1013. https://doi.org/10.1007/s00227-013-2382-6

Becker, P., D. C. Gillan, and I. Eeckhaut. 2007. "Microbiological study of the body wall lesions of the echinoid Tripneustes gratilla." Dis. Aquat. Org. 77: 73-82. https://doi. org/10.3354/dao01821

Becker, P. T., E. Egea, and I. Eeckhaut. 2008. "Characterization of the bacterial communities associated with the bald sea urchin disease of the echinoid Paracentrotus lividus." J. Invertebr. Pathol. 98: 136-147. https://doi.org/10.1016/j. jip.2007.12.002

Benítez-Villalobos, F., J. P. Díaz Martínez, and M. Martínez-García. 2009. "Mass mortality of the sea urchin Diadema mexicanum in La Entrega at Bahias de Huatulco, Western Mexico." Coral Reefs 28: 1017. https://doi. org/10.1007/s00338-009-0541-5

Biggar, R. B., and D. H. Wenrich. 1932. "Studies on ciliates from Bermuda sea urchins.” J. Parasitol. 18: 252-257. https://doi.org/10.1186/1742-9994-6-10

Bodmer, M. D. V., A. D. Rogers, M. R. Speight, N. Lubbock, and D. A. Exton. 2015. "Using an isolated population boom to explore barriers to recovery in the keystone Caribbean coral reef herbivore Diadema antillarum." Coral Reefs 34: 1011-1021. https://doi.org/10.1007/s00338-015-1329-4

Boudouresque, C.-F., H. Nedelec, and S. A. Shepherd. 1980. "The decline of a population of the sea urchin Paracentrotus lividus in the Bay of Port-Cros (Var, France)." Trav. Sci. Parc Nation Port-Cros Fr. 6: 243-251.
Buchwald, R. T., C. J. Feehan, R. E. Scheibling, and A. G. B. Simpson. 2015. "Low temperature tolerance of a sea urchin pathogen: Implications for benthic community dynamics in a warming ocean." J. Exp. Mar. Biol. Ecol. 469: 1-9. https://doi.org/10.1016/j.jembe.2015.04.006

Carpenter, R. C. 1988. "Mass mortality of a Caribbean sea urchin: Immediate effects on community metabolism and other herbivores." Proc. Natl. Acad. Sci. USA 85: 511-514. https://doi.org/10.1073/pnas.85.2.511

Carpenter, R. C. 1990a. "Mass mortality of Diadema antillarum I. Long-term effects on sea urchin populationdynamics and coral reef algal communities." Mar. Biol. 104: 67-77. https://doi.org/10.1007/BF01313159

Carpenter, R. C. 1990b. "Mass mortality of Diadema antillarum II. Effects on population densities and grazing intensity of parrotfishes and surgeonfishes." Mar. Biol. 104: 79-86. https://doi.org/10.1007/BF01313160

Cavey, M. J., and K. Märkel. 1994. "Echinoidea." In Microscopic Anatomy of Invertebrates, Vol. 14, Echinodermata, edited by F. W. Harrison and F. Chia. 345-400. New York: Wiley-Liss, Inc.

Chiappone, M., L. M. Rutten, D. W. Swanson, and S. L. Miller. 2008. "Population status of the urchin Diadema antillarum in the Florida Keys 25 years after the Caribbean mass mortality." In 11th International Coral Reef Symposium Proceedings, edited by B. Riegl and R. E. Dodge. 706-710. Ft. Lauderdale, FL. https://nsuworks.nova.edu/ occ_icrs/1

Chiappone, M., D. Swanson, S. Miller, and S. Smith. 2002. "Large-scale surveys on the Florida Reef Tract indicate poor recovery of the long-spined sea urchin Diadema antillarum." Coral Reefs 21: 155-159.

Clemente, S., J. Lorenzo-Morales, J. C. Mendoza, C. López, C. Sangil, F. Alves, M. Kaufmann, and J. C. Hernández. 2014. "Sea urchin Diadema africanum mass mortality in the subtropical eastern Atlantic: Role of waterborne bacteria in a warming ocean." Mar. Ecol. Prog. Ser. 506: 1-14. https://doi.org/10.3354/meps10829

Dame, E. A. 2008. "Assessing the effect of artificial habitat structure on translocation of the long-spined sea urchin, Diadema antillarum, in Curacao (Netherlands Antilles)." Bull. Mar. Sci. 82(2): 247-254. 
de Ruyter Van Steveninck, E. D., and R. P. M. Bak. 1986. "Changes in abundance of coral-reef bottom components related to mass mortality of the sea urchin Diadema antillarum." Mar. Ecol. Prog. Ser. 34: 87-94. https://doi. org/10.3354/meps034087

de Ruyter van Steveninck, E. D., and A. M. Breeman. 1987. "Deep water vegetations of Lobophora variegata (Phaeophyceae) in the coral reef of Curacao-Population dynamics in relation to mass mortality of the sea urchin Diadema antillarum." Mar. Ecol. Prog. Ser. 36: 81-90. https://doi.org/10.3354/meps036081

Dumont, C. P., J. H. Himmelman, and M. P. Russell. 2004. "Sea urchin mass mortality associated with algal debris from ice scour." In Echinoderms: Munchen, edited by T. Heinzeller and J. Nebelsick. 177-182. Munich: Taylor \& Francis.

Dykova, I., J. Lorenzo-Morales, M. Kostka, B. Valladares, and H. Peckova. 2011. "Neoparamoeba branchiphila infections in moribund sea urchins Diadema aff. antillarum in Tenerife, Canary Islands, Spain.” Dis. Aquat. Org. 95: 225-231. https://doi.org/10.3354/dao02361

Feehan, C. J., J. Johnson-Mackinnon, R. E. Scheibling, J. S. Lauzon-Guay, and A. G. Simpson. 2013. "Validating the identity of Paramoeba invadens, the causative agent of recurrent mass mortality of sea urchins in Nova Scotia, Canada." Dis. Aquat. Org. 103: 209-227. https://doi. org/10.3354/dao02577

Feehan, C. J., and R. E. Scheibling. 2014. "Effects of sea urchin disease on coastal marine ecosystems." Mar. Biol. 161: 1467-1485. https://doi.org/10.1007/s00227-014-2452-4

Feehan, C. J., M. S. Brown, W. C. Sharp, J. S. Lauzon-Guay, and D. K. Adams. 2016. "Fertilization limitation of Diadema antillarum on coral reefs in the Florida Keys." Ecology. 97(8): 1897-1904. https://doi.org/10.1002/ecy.1461

Forcucci, D. 1994. "Population density, recruitment and 1991 mortality event of Diadema antillarum in the Florida Keys." Bull. Mar. Sci. 54: 917-928.

Francis-Floyd, R., J. Landsberg, R. Yanong, S. Baker, N. Stacy, T. Waltzek, Y. Kiryu, J. Hunt, W. Sharp, R. Smolowitz, G. Beck, K. Leber, D. Vaughan, and M. Moe. 2016. "Final Report: Development of a Health Protocol for Hatchery-Reared Long-Spined Sea Urchin, Diadema antillarum." Florida Fish and Wildlife Conservation Commission Agreement No. 14044, SWG CFDA No. 15634. Tallahassee, FL.
Furman, B., and K. L. Heck. 2009. "Differential impacts of echinoid grazers on coral recruitment." Bull. Mar. Sci. 85: 121-132.

Garcia, L. S., and D. A. Bruckner. 1993. "Macroscopic and microscopic examination of fecal specimens." In Diagnostic Medical Parasitology, 2nd Edition. Washington, D.C.: American Society for Microbiology. 501-540.

Gardner, T. A., I. M. Cote, J. A. Gill, A. Grant, and A. R. Watkinson. 2003. "Long-term region-wide declines in Caribbean corals." Science 301: 958-960. https://doi. org/10.1126/science. 1086050

Gilles, K. W., and J. S. Pearse. 1986. "Disease in sea urchins Strongylocentrotus purpuratus: Experimental infection and bacterial virulence." Dis. Aquat. Org. 1: 105-114. https:// doi.org/10.3354/dao001105

Girard, D., S. Clemente, K. Toledo-Guedes, A. Brito, and J. C. Hernández. 2012. "A mass mortality of subtropical intertidal populations of the sea urchin Paracentrotus lividus: Analysis of potential links with environmental conditions." Mar. Ecol. 33: 377-385. https://doi. org/10.1111/j.1439-0485.2011.00491.x

Groliere, C. A., Pd. Puytorac, and J. Grain. 1980. "Observations de quelques especes de cilies endocommensaux d'echinides du Golfe du Mexique et de la mer des Antilles." Protistol 16: 233-239.

Hagen, N. T. 1987. "Sea urchin outbreaks and nematode epizootics in Vestfjorden, northern Norway." Sarsia 72: 213-229. https://doi.org/10.1080/00364827.1987.10419719

Hagen, N. T. 1992. "Macroparasitic epizootic disease: a potential mechanism for the termination of sea urchin outbreaks in northern Norway?” Mar. Biol. 114: 469-478. https://doi.org/10.1007/BF00350039

Hagen, N. T. 1996. "Parasitic castration of the green echinoid Strongylocentrotus droebachiensis by the nematode endoparasite Echinomermella matsi: Reduced reproductive potential and reproductive death." Dis. Aquat. Org. 24: 215-226. https://doi.org/10.3354/dao024215

Harms, C. A. 2006. "Echinoderms." In Invertebrate Medicine, edited by G. A. Lewbart. 245-256. Ames, IA: Blackwell Publishing. https://doi.org/10.1002/9780470344606. ch17 
Hendler, G. 2013. "Recent mass mortality of Strongylocentrotus purpuratus (Echinodermata: Echinoidea) at Malibu and a review of purple sea urchin kills elsewhere in California." Bull. South Cal. Acad. Sci. 112: 19-37. https:// doi.org/10.3160/0038-3872-112.1.19

Hughes, T. P., B. D. Keller, J. B. C. Jackson, and M. J. Boyle. 1985. "Mass mortality of the echinoid Diadema antillarum Philippi in Jamaica." Bull. Mar. Sci. 36: 377-384.

Hughes, T. P., D. C. Reed, and M. J. Boyle. 1987. "Herbivory on coral reefs: Community structure following mass mortalities of sea urchins." J. Exp. Mar. Biol. Ecol. 113: 39-59. https://doi.org/10.1016/0022-0981(87)90081-5

Hunte, W., I. Côté, and T. Tomascik. 1986. "On the dynamics of the mass mortality of Diadema antillarum in Barbados.” Coral Reefs 4: 135-139. https://doi.org/10.1007/ BF00427934

Jackson, J. B. C. 2008. "Ecological extinction and evolution in the brave new ocean." Proc. Natl. Acad. Sci. USA 105: 11458-11465. https://doi.org/10.1073/pnas.0802812105

Jangoux, M. 1984. "Diseases of echinoderms." Helgo Meeresunters 37: 207-216. https://doi.org/10.1007/BF01989305

Jangoux, M. 1987a. "Diseases of Echinodermata. I. Agents microorganisms and protistans." Dis. Aquat. Org. 2: $147-162$.

Jangoux, M. 1987b. "Diseases of Echinodermata. II. Agents metazoans (Mesozoa to Bryozoa)." Dis. Aquat. Org. 2: 205-234. https://doi.org/10.3354/dao002205

Jangoux, M. 1987c. "Diseases of Echinodermata. III. Agents metazoans (Annelida to Pisces)." Dis. Aquat. Org. 3: 59-83. https://doi.org/10.3354/dao003059

Jangoux, M. 1987d. “Diseases of Echinodermata. IV. Structural abnormalities and general considerations on biotic diseases." Dis. Aquat. Org. 3: 221-229. https://doi. org/10.3354/dao003221

Jangoux, M. 1990. "Diseases of Echinodermata." In Diseases of Marine Animals, Book 3, edited by O. Kinne. 439-567. Hamburg, Germany: Biologische Anstalt Helgoland.
Jellett, J. F., A. C. Wardlaw, and R. E. Scheibling. 1989. “Experimental infection of the sea urchin (Strongylocentrotus droebachiensis) with a pathogenic amoeba (Paramoeba invadens): Quantitative changes in the coelomic fluid in vivo and cellular interaction in vitro." Dev. Comp. Immunol. 13: 428-429. https://doi.org/10.1016/0145-305X(89)90152-3

Jones, G. M., and R. E. Scheibling. 1985. "Paramoeba sp. (Amoebida, Paramoebidae) as the possible causative agent of sea urchin mass mortality in Nova Scotia." J. Parasitol. 71: 559-565. https://doi.org/10.2307/3281424

Jones, G. M., R. E. Scheibling, A. J. Hebda, and R. J. Miller. 1985. "Amoebae in tissues of diseased echinoids (Strongylocentrosus droebachiensis) in Nova Scotia." In Proceedings of the Fifth International Echinoderm Conf., B. F. Keegan and B. D. S. O'Connor (Eds), Galway, Ireland, Sep 24-29 1984. Rotterdam: Balkema. 289-293.

Jones, I. W., and T. E. Rogers. 1968. "Studies on the endocommensal ciliate fauna of Caribbean sea urchins." Biol. Bull. 135: 514-519. https://doi.org/10.2307/1539713

Jurgens, L. J., L. Rogers-Bennett, P. T. Raimondi, L. M. Schiebelhut, M. N. Dawson, R. K. Grosberg, and B. Gaylord. 2015. "Patterns of mass mortality among rocky shore invertebrates across $100 \mathrm{~km}$ of northeastern Pacific coastline." PloS One 10: e0126280. https://doi.org/10.1371/ journal.pone. 0126280

Kissling, D. L., W. F. Precht, S. L. Miller, and M. Chiappone. 2014. "Historical reconstruction of population density of the echinoid Diadema antillarum on Florida Keys shallow bank-barrier reefs." Bull. Mar. Sci. 90: 665-679. https://doi.org/10.5343/bms.2013.1022

Knowlton, N. 2001. "Sea urchin recovery from mass mortality: New hope for Caribbean coral reefs?" Proc. Natl. Acad. Sci. USA 98: 4822-4824. https://doi.org/10.1073/ pnas.091107198

Lessios, H. A. 1988. "Mass mortality of Diadema antillarum in the Caribbean: What have we learned?" Annu. Rev. Ecol. Syst. 19: 371-393. https://doi.org/10.1146/annurev. es.19.110188.002103

Lessios, H. A. 1995. "Diadema antillarum 10 years after mass mortality: Still rare, despite help from a competitor." Proc. Roy. Soc. Lond. Series B: Biol. Sci. 259: 331-337. https://doi.org/10.1098/rspb.1995.0049 
Lessios, H. A. 2005. “Diadema antillarum populations in Panama twenty years following mass mortality." Coral Reefs 24: 125-127. https://doi.org/10.1007/ s00338-004-0443-5

Lessios, H. A. 2016. "The great Diadema antillarum die-off: 30 years later.” Annu. Rev. Mar. Sci. 8: 267-283. https://doi. org/10.1146/annurev-marine-122414-033857

Lessios, H. A., J. D. Cubit, D. R. Robertson, M. J. Shulman, M. R. Parker, S. D. Garrity, and S. C. Levings. 1984a. "Mass mortality of Diadema antillarum on the Caribbean coast of Panama." Coral Reefs 3: 173-182. https://doi.org/10.1007/ BF00288252

Lessios, H., P. Glynn, and D. Robertson. 1983. "Mass mortalities of coral reef organisms.” Science 222: 715. https://doi.org/10.1126/science.222.4625.715

Lessios, H. A., D. R. Robertson, and J. D. Cubit. 1984b. "Spread of Diadema mass mortality through the Caribbean." Science 226: 335-337. https://doi.org/10.1126/ science.226.4672.335

Lester, S. E., E. D. Tobin, and M. D. Behrens. 2007. “Disease dynamics and the potential role of thermal stress in the sea urchin, Strongylocentrotus purpuratus." Can. J. Fish Aquat. Sci. 64: 314-323. https://doi.org/10.1139/f07-010

Levitan, D. R. 1988. "Algal-urchin biomass responses following mass mortality of Diadema antillarum Philippi at Saint John, U.S. Virgin Islands." J. Exp. Mar. Biol. Ecol. 119: 167-178. https://doi.org/10.1016/0022-0981(88)90231-6

Li, T., and S. Xu. 2000. "Preliminary studies on the black mouth disease of sea urchin, Strongylocentrotus intermedius (Strongylocentrotidae Echinoidea)." Mar. Sci. Qingdao 24: 43-47.

Liddell, W. D., and S. L. Ohlhorst. 1986. "Changes in benthic community composition following the mass mortality of Diadema at Jamaica." J. Exp. Mar. Biol. Ecol. 95: 271-278. https://doi.org/10.1016/0022-0981(86)90259-5

Luna, L. G. 1968. Manual of Histologic Staining Methods of the Armed Forces Institutes of Pathology, 3rd Edition. New York: McGraw-Hill.

Maes, P., and M. Jangoux. 1984. “The bald-sea-urchin disease: a biopathological approach.” Helgol Meeresunters 37: 217-224. https://doi.org/10.1007/BF01989306
Martony, M., D. Pouder, R. Yanong, Y. Kiryu, J. H. Landsberg, R. Isaza, T. Waltzek, N. Stacy, R. Giglio, S. Baker, and R. Francis-Floyd. 2018. "Establishing a diagnostic technique for coelomocentesis in the long-spined sea urchin Diadema antillarum." Journal of Aquatic Animal Health. https://doi.org/10.1002/aah.10043

Masuda, Y., K. Tajima, and Y. Ezura. 2004. "Resuscitation of Tenacibaculum sp., the causative bacterium of spotting disease of sea urchin Strongylocentrotus intermedius, from the viable but non-culturable state." Fish Sci. 70: 277-284.

McClendon, J. F. 1912. "Echinochrome, a red substance in sea urchins.” J. of Biol. Chem. 11: 435-441.

McManus, J. W., and J. F. Polsenberg. 2004. "Coral-algal phase shifts on coral reefs: Ecological and environmental aspects." Prog. Oceanogr. 60: 263-279. https://doi. org/10.1016/j.pocean.2004.02.014

Miller, R., A. Adams, N. Ogden, J. Ogden, and J. Ebersole. 2003. "Diadema antillarum 17 years after mass mortality: Is recovery beginning on St. Croix?" Coral Reefs 22: 181-187. https://doi.org/10.1007/s00338-003-0301-x

Miller, R. J., and A. G. Colodey. 1983. "Widespread mass mortalities of the green sea urchin in Nova Scotia, Canada." Mar. Biol. 73: 263-267. https://doi.org/10.1007/ BF00392252

Mumby, P. J., J. D. Hedley, K. Zychaluk, A. R. Harborne, and P. G. Blackwell. 2006. "Revisiting the catastrophic die-off of the urchin Diadema antillarum on Caribbean coral reefs: Fresh insights on resilience from a simulation model." Ecol. Model 196: 131-148. https://doi.org/10.1016/j. ecolmodel.2005.11.035

Murillo-Castro, M. M., and J. Cortés-Núñez. 1984. “Alta mortalidad en la población del erizo de mar Diadema antillarum Philippi (Echinodermata: Echinoidea), en el Parque Nacional Cahuita, Limón, Costa Rica." Rev. Biol. Trop. 32: 167-169.

Nagelkerken, I., G. W. Smith, E. Snelders, M. Karel, and S. James. 1999. "Sea urchin Meoma ventricosa die-off in Curacao (Netherlands Antilles) associated with a pathogenic bacterium." Dis. Aquat. Org. 38: 71-74. https://doi. org/10.3354/dao038071

NOAA/FKNMS. 2015. "Florida Keys National Marine Sanctuary 2011 Condition Report.” Accessed March 24, 2016. http://sanctuaries.noaa.gov/science/condition/fknms/ state.html 
Noga, E. J. 2010. Fish Disease: Diagnosis and Treatment, 2nd Edition. 13-48. Ames, IA: Wiley Blackwell. https://doi. org/10.1002/9781118786758

Pearse, J. S., D. P. Costa, M. B. Yellin, and C. R. Agegian. 1977. "Localized mass mortality of red sea urchin, Strongylocentrotus franciscanus, near Santa Cruz, California." Fish Bull. 75: 645-648.

Phinney, J. T., F. Muller-Karger, P. Dustan, and J. Sobel. 2001. "Using remote sensing to reassess the mass mortality of Diadema antillarum 1983-1984." Conserv. Biology 15: 885-891.

https://doi.org/10.1046/j.1523-1739.2001.015004885.x

Quintero-Hunter, I., H. Grier, and M. Muscato. 1991. "Enhancement of histological detail using metanil yellow as a counterstain in periodic acid/Schiff's hematoxylin staining of glycol methacrylate tissue sections." Biotech. Histochem. 66: 169-172. https://doi.org/10.3109/10520299109109964

Roberts-Regan, D. L., R. E. Scheibling, and J. F. Jellett. 1988. "Natural and experimentally induced lesions of the body wall of the sea urchin Strongylocentrotus." Dis. Aquat. Org. 5: 51-62. https://doi.org/10.3354/dao005051

Rogers, A., and K. Lorenzen. 2016. "Does slow and variable recovery of Diadema antillarum on Caribbean fore-reefs reflect density-dependent habitat selection?" Front Mar. Sci. Vol 3, Article 63. https://doi.org/10.3389/fmars.2016.00063

Scheibling, R. E., C. M. Feehan, and J. S. Lauzon-Guay. 2010. "Disease outbreaks associated with recent hurricanes cause mass mortality of sea urchins in Nova Scotia." Mar. Ecol. Prog. Ser. 408: 109-116. https://doi.org/10.3354/ meps08579

Scheibling, R. E., and A. W. Hennigar. 1997. "Recurrent outbreaks of disease in sea urchins Strongylocentrotus droebachiensis in Nova Scotia: Evidence for a link with large-scale meteorologic and oceanographic events." Mar. Ecol. Prog. Ser. 152: 155-165. https://doi.org/10.3354/ meps152155

Scheibling, R. E., and R. L. Stephenson. 1984. "Mass mortality of Strongylocentrotus droebachiensis (Echinodermata: Echinoidea) off Nova Scotia, Canada." Mar. Biol. 78: 153-164. https://doi.org/10.1007/BF00394695
Sharp, W. C., G. A. Delgado, J. E. Hart, and J. H. Hunt. 2018. "Comparing the behavior and morphology of wildcollected and hatchery-propagated long-spined sea urchins (Diadema antillarum): Implications for coral reef ecosystem restoration.” Bull. Mar. Sci. 94(1): 103-122. https://doi. org/10.5343/bms.2017.1068

Shimizu, M. 1994. "Histopathological investigation of the spotted gonad disease in the sea urchin, Strongylocentrotus intermedius." J. Invert. Pathol. 63: 182-187. https://doi. org/10.1006/jipa.1994.1034

Sivertsen, K. 1996. "Incidence, occurrence and distribution of the nematode Echinomermella matsi in its echinoid host, Strongylocentrotus droebachiensis, in northern Norway." Mar. Biol.: 703. https://doi.org/10.1007/BF00351337

Skadsheim, A., H. Christie, and H. P. Leinaas. 1995. "Population reductions of Strongylocentrotus droebachiensis (Echinodermata) in Norway and the distribution of its endoparasite Echinomermella matsi (Nematoda)." Mar. Ecol. Prog. Ser. 119: 199-209. https://doi.org/10.3354/ meps119199

Sogabe, Y., K. Tajima, R. Tanaka, T. Sawabe, and Y. Ezura. 2002. "Development of $16 \mathrm{~S}$ rRNA targeted PCR for the identification of Vibrio spp., the causative bacteria of the disease in cultured sea urchin Strongylocentrotus intermedius occurring at low water temperatures." Bull. Jap. Soc. Sci. Fish 68: 201-206. https://doi.org/10.2331/suisan.68.201

Stacy, N. I., T. Frankovich, H. Walden, and R. FrancisFloyd. 2018. "From macro- to microcosm: the art and beauty of plant material and diatoms in sea urchin fecal cytology specimens." Vet. Clin. Pathol. 47(4): 525-526.

Stien, A. 1999. "Effects of the parasitic nematode Echinomermella matsi on growth and survival of its host, the sea urchin Strongylocentrotus droebachiensis." Can. J. Zool. 77: 139-147. https://doi.org/10.1139/z98-159

Stien, A., H. P. Leinaas, O. Halvorsen, and H. Christie. 1998. "Population dynamics of the Echinomermella matsi (Nematoda) Strongylocentrotus droebachiensis (Echinoida) system: Effects on host fecundity." Mar. Ecol. Prog. Ser. 163: 193-201. https://doi.org/10.3354/meps163193

Tajima, K., J. R. M. Cunha da Silva, and J. M. Lawrence. 2007. "Disease in sea urchins." In Edible Sea Urchins: Biology and Ecology, J. M. Lawrence (Ed). Elsevier, Amsterdam. 167-189. https://doi.org/10.1016/S0167-9309(07)80073-1 
Tajima, K., T. Hirano, K. Nakano, and Y. Ezura. 1997a. "Taxonomical study on the causative bacterium of spotting disease of sea urchin Strongylocentrotus intermedius." Fish Sci. 63: 897-900. https://doi.org/10.2331/fishsci.63.897

Tajima, K., T. Hirano, M. Shimizu, and Y. Ezura. 1997b. "Isolation and pathogenicity of the causative bacterium of spotting disease of sea urchin Strongylocentrotus intermedius." Fish Sci. 63: 249-252. https://doi.org/10.2331/ fishsci.63.897

Tajima, K., and J. M. Lawrence. 2001. "Disease in edible sea urchins." In Edible Sea Urchins: Biology and Ecology, Book 32, edited by J. M. Lawrence. 139-148. Elsevier B.V., Amsterdam. https://doi.org/10.1016/S0167-9309(01)80010-7

Tajima, K., M. Shimizu, K. Miura, S. Ohsaki, Y. Nishihara, and Y. Ezura. 1998. "Seasonal fluctuations of Flexibacter sp. the causative bacterium of spotting disease of sea urchin Strongylocentrotus intermedius in the culturing facilities and coastal area." Fish Sci. 64: 6-9. https://doi.org/10.2331/ fishsci.64.6

Takeuchi, K., K. Tajima, M. M. Iqbal, T. Sawabe, and Y. Ezura. 1999. "Taxonomical and serological studies on the causative bacteria of the disease of sea urchin Strongylocentrotus intermedius occurring at low water temperatures." Fish Sci. 65: 264-268. https://doi.org/10.2331/fishsci.65.264

Taniuchi, Y., K. Tajima, I. Shimono, and Y. Ezura. 2002. "Survival of Flexibacter sp. strain F-2, the causative bacterium of spotting disease of sea urchin Strongylocentrotus intermedius at low temperatures." Bull. Jap. Soc. Sci. Fish: 46-51.

Urdaneta-Morales, S., and M. T. De McLure. 1966. "The endocommensal ciliates of Venezuelan sea urchins.” J. Protozool. 13: 5-8. https://doi.org/10.1111/j.1550-7408.1966. tb01859.x

Uthicke, S., B. Schaffelke, and M. Byrne. 2009. “A boombust phylum? Ecological and evolutionary consequences of density variations in echinoderms." Ecol. Monogr. 79: 3-24. https://doi.org/10.1890/07-2136.1

Violetta, H., R. Francis-Floyd, R. P. E. Yanong, and J. H. Landsberg. 2017. "Validation of health assessment criteria for Diadema antillarum." Proceedings of the 48th Conference of the International Association for Aquatic Animal Medicine, Cancun MX (May 22 2017).
Wang, Y., N. Feng, Q. Li, J. Ding, Y. Zhan, and Y. Chang. 2013a. "Isolation and characterization of bacteria associated with a syndrome disease of sea urchin Strongylocentrotus intermedius in North China." Aquac. Res. 44: 691-700. https://doi.org/10.1111/j.1365-2109.2011.03073.x

Wang, Y. N., Y. Q. Chang, and J. M. Lawrence. 2013b. "Disease in sea urchins." In Sea Urchins: Biology and Ecology, edited by J. M. Lawrence. Elsevier B. V., Amsterdam. 179-186. https://doi.org/10.1016/ B978-0-12-396491-5.00012-5

Ward, J. R., and K. D. Lafferty. 2004. “The elusive baseline of marine disease: Are diseases in ocean ecosystems increasing?" PLoS Biol. 2: E120. https://doi.org/10.1371/ journal.pbio.0020120

Weil, E., J. L. Torres, and M. Ashton. 2005. "Population characteristics of the sea urchin Diadema antillarum in La Parguera, Puerto Rico, 17 years after the mass mortality event." Rev. Biol. Trop. 53(Suppl. 3): 219-231.

Williams, E. H., L. Bunkley-Williams, R. J. Bruckner, A. W. Bruckner, E. A. R. Ortiz-Corps, W. A. Bowden-Kerby, and D. E. Colon-Jones. 1996. "Recurring mass mortalities of the white-spined sea urchin, Tripneustes ventricosus (Echinodermata: Echinoidea) in Puerto Rico." Caribb. J. Sci. 32: 111.

Williams, L. B., E. H. Williams, Jr., and A. G. Bunkley, Jr. 1986. "Isolated mortalities of the sea urchins Astropyga magnifica and Eucidaris tribuloides in Puerto Rico." Bull. Mar.Sci. 38: 391-393.

Williams, S., P. Yoshioka, and J. García Sais. 2010. "Recruitment pattern of Diadema antillarum in La Parguera, Puerto Rico." Coral Reefs 29: 809. https://doi.org/10.1007/ s00338-010-0633-2

Ziegler, A., C. Faber, and T. Bartolomaeus. 2009.

"Comparative morphology of the axial complex and interdependence of internal organ systems in sea urchins (Echinodermata: Echinoidea)." Frontiers in Zoology 6: 10. https://doi.org/10.1186/1742-9994-6-10 


\section{Diadema antillarum Health Evaluation-Site Collection}

\section{Field Collection Information}

Collection date:

Collection area:

Location/GPS Coordinates:

$\square$ Upper Keys

Middle Keys

Collected by:

Site substrate:

$\square$ Sand

Water depth:

Surface water temperature:

Number of adults collected:

\section{Population In-Field Behavioral Assessment}

\section{Assessment Based on Population at Collection Site}

Sheltered (in situ)? $\quad$ Yes__ $\% \quad$ No __ $\%$

Body position (in situ): Normal ___ $\%$ Upside Down _ $\%$

Bottom water temperatrue:

Number of juveniles collected:

Spine position: $\quad$ Normal (up) __ $\%$ Drooping ___ $\%$

Attachment tenacity to substrate: Weak_\% Strong_\%

Comments:

FOR USE BY NECROPSY TEAM:

Assigned Accession Numbers 


\section{Behavioral and Physical Assessment}

Exam date: Exam time: AM/PM Examined by:

\section{Gross Exam}

Weight (before fluid collection): g

Attachment tenacity to substrate: $\quad \square$ Weak

Strong

Tube feet activity:

Low

High

Light/shadow activity response: $\quad \square$ None

Moves away from light stimuli

Touch response:

$\square$ None

Moves away

Raises spines toward threat

Spine position:

$\square$ Normal (up)

Drooping

Righting behavior:

Unable to right

Voluntary/active defecation?

$\square$ Yes

$\square$ No

Predominant spine color: $\square$ Black $\quad \square$ Purple $\quad \square$ Gray $\quad \square$ White $\quad \square$ Other

White spines (if present): Estimated \%: Location:

Striped/variegated spines? $\quad \square$ Yes-Tips/Length of of spines

Loss of spines? $\quad \square$ Yes

$\square$ No If yes, estimated \%:

Broken spines?

$\square$ Yes-Tips/Base

$\square$ No If yes, estimated \%:

Test exposed?

$\square$ Yes

$\square$ No If yes, estimated \%:

Bare skeleton visible?

$\square$ Yes

$\square$ No If yes, estimated \%:

Overgrowth of algae on test? $\quad \square$ Yes

$\square$ No If yes, estimated \%:

Voluntary spawning during exam? $\square$ Yes $\square$ No

\section{Animal Size}

Remove Spines

Test diameter $\mathrm{x}$ test height (spines removed):

$\mathrm{mm} \times$ $\mathrm{mm}$ 


\section{Dissecting Microscope Exam}

Ulceration of epidermis?

$\square$ Yes

No If yes, estimated \%:

Epibionts present?

$\square$ Yes

No If yes, describe:

If epibiont present, were they preserved? $\square$ Yes $\square$ No If yes, describe:

Pedicellaria activity: $\quad \square$ Low $\quad \square$ High

Condition of pedicellaria: $\quad \square$ Normal $\quad \square$ Abnormal

Condition of tube feet: $\quad \square$ Normal $\quad \square$ Abnormal

Aristotle's Lantern: $\quad \square$ Normal $\square$ Abnormal $\square$ Prolapsed jaw

Active teeth/mouth? $\quad \square$ Yes $\quad \square$ No

Prolapsed anus? $\quad \square$ Yes $\quad \square$ No

Color of peristomial membrane:

Lesion(s) present? $\quad \square$ Yes $\quad \square$ No (If yes, complete lesion descriptions below.)

Note: Examination with dissecting microscope required for lesion description

Description of lesion(s): $\quad \square$ Focal $\quad \square$ Multi-focal $\square$ Diffuse

Lesion 1:

Diameter: $\mathrm{mm}$

Epidermis missing? $\square$ Yes $\square$ No

Necrotic material present? $\square$ Yes

$\square$ No

Lesion color:

Margin color:

Note: Mark lesions on diagrams on next page

Photograph(s) taken? $\quad \square$ Yes $\quad \square$ No

Photographer/camera:

Comments:
Lesion 2:

Diameter: $\mathrm{mm}$

Epidermis missing? $\quad \square$ Yes $\square$ No

Necrotic material present? $\square$ Yes $\quad \square$ No Lesion color:

Margin color:

Views: 


\section{Label Lesions on Diagrams Below}

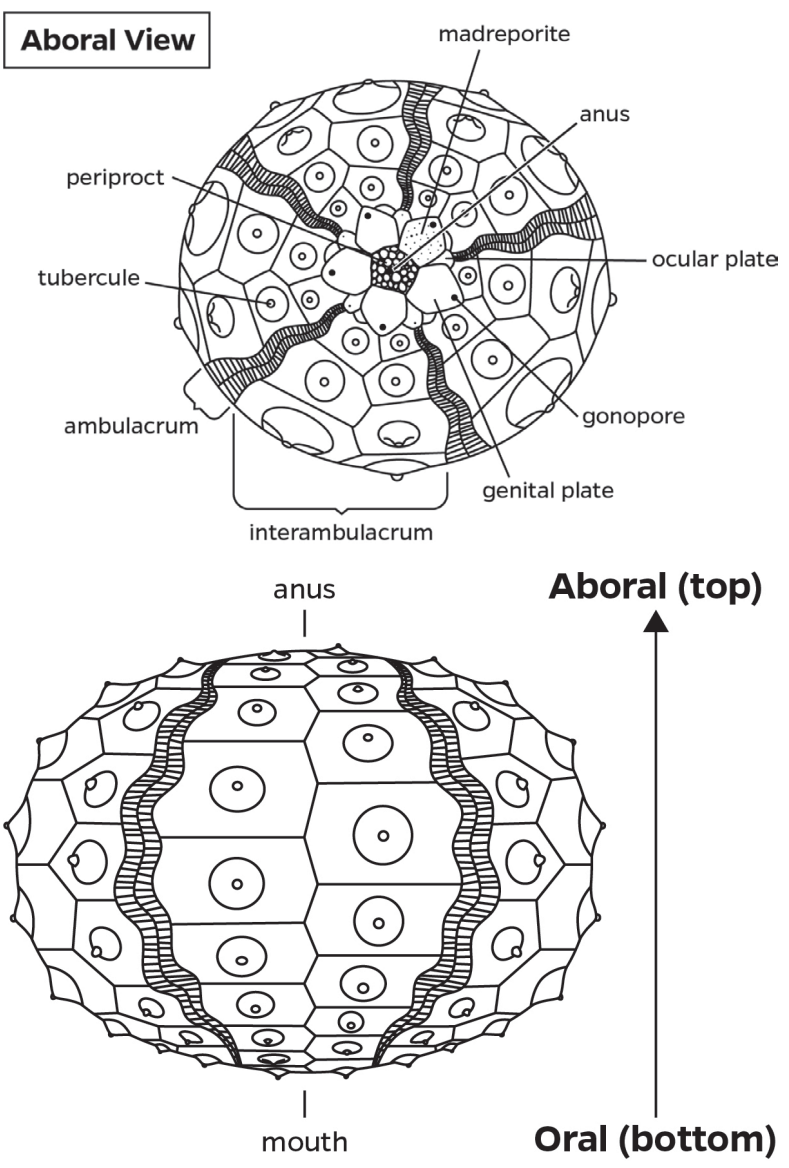

Coelomic Fluid Collection
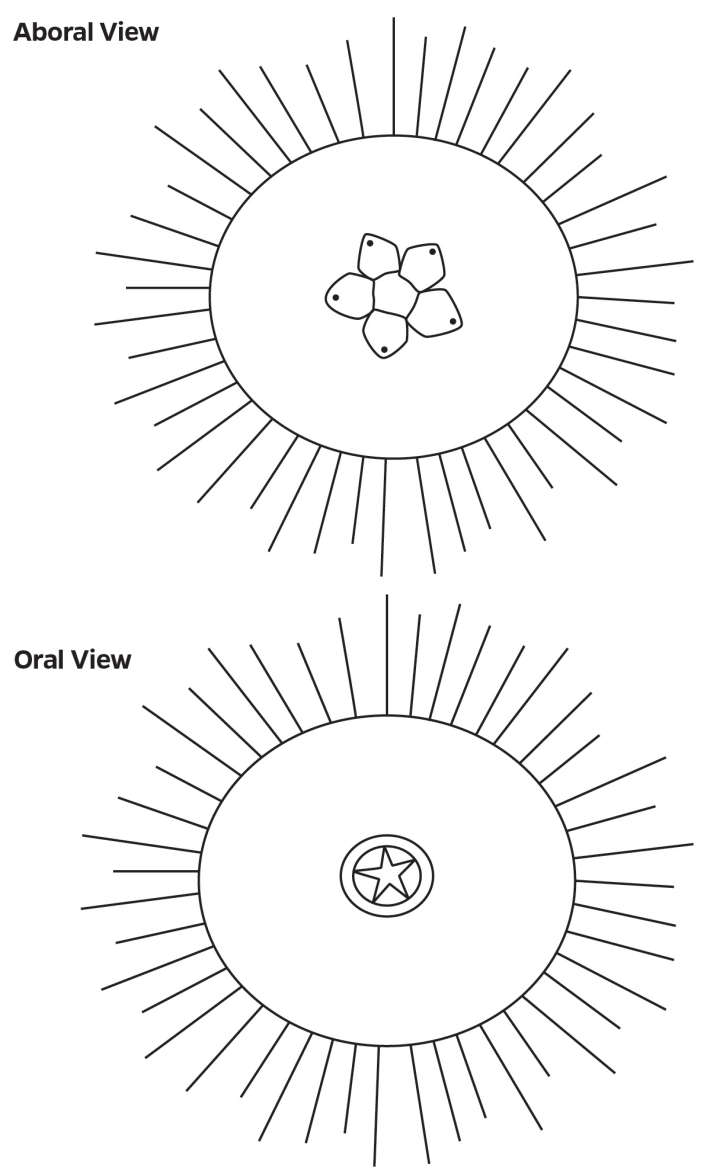

Illustrations by Heather Griffith, UF/IFAS

Fluid samples collected: $\square$ Yes $\square$ No Collection time: AM/PM Collected by:

Total volume removed: $\mathrm{mL} \quad$ Needle gauge:

Fluid color: $\quad \square$ Clear $\quad \square$ Pink $\quad \square$ Other Fluid contains: $\square$ Pink coagulation $\quad \square$ Brown material $\quad \square$ Other Comments:

\begin{tabular}{|l|l|l|l|}
\hline & Bacteriology & Cytology & Immunology \\
\hline Volume $(\mathrm{mL})$ & & & \\
\hline Anticoagulant & & & \\
\hline
\end{tabular}

Fluid cytology: \# of slides prepared 


\section{Bacteriology Collection/Submission}

Bacteriology samples collected: $\square$ Yes $\square$ No Collection time: AM/PM Collected by:

Tissues cultured: $\square$ Coelomic Fluid $\quad \square$ Lesion $\quad \square$ Spines (2 primary) $\quad \square$ Other

Liquid growth media: $\quad \square$ TSB Incubation Temp: ${ }^{\circ} \mathrm{C}$ Incubation Time: hrs

Submitted to: Date: Transport:

Comments:

\section{Internal Exam}

\section{Compound Microscope Exam}

Exam performed: $\square$ Yes $\quad \square$ No Exam time: AM/PM Performed by:

Wetmounts:

Spines:

Test:

Gut/Feces:

Gonad: testes/ovary

Description (size, maturity, etc.):

Coelomic fluid:

Other:

Comments:

Photograph(s) taken? $\square$ Yes $\square$ No Views:

Photographer/camera:

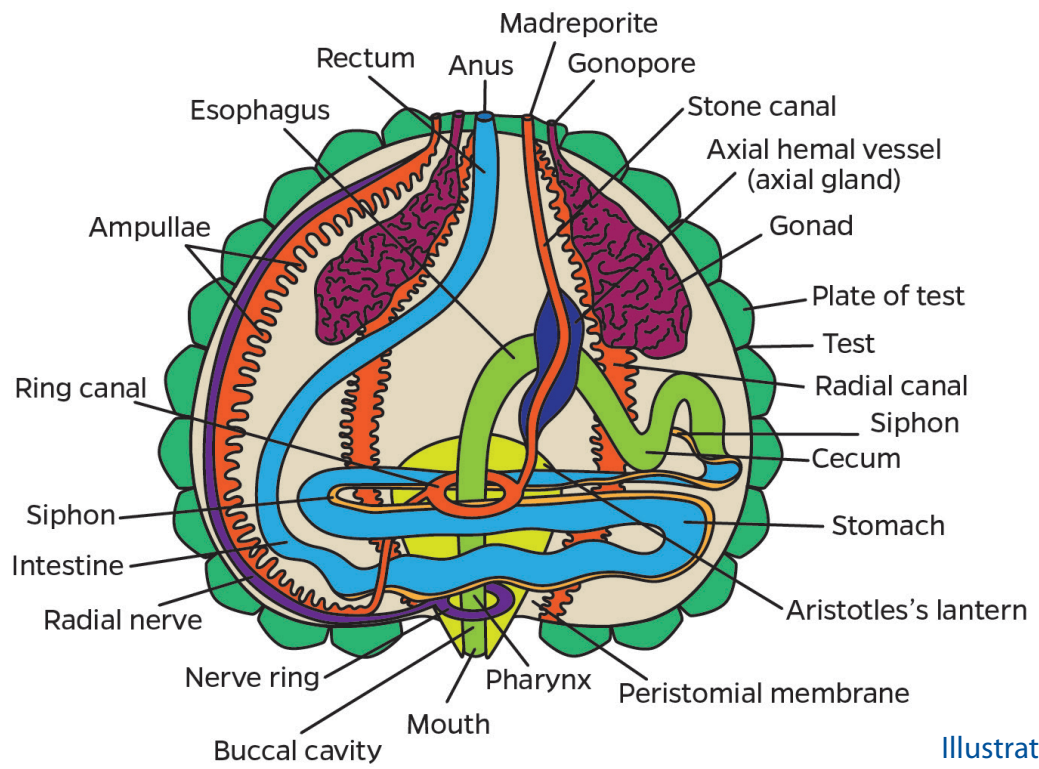




\section{Gross \& Dissecting Microscope Exam}

Exam performed: $\quad \square$ Yes $\quad \square$ No Exam time: AM/PM Performed by:

Tissues examined:

Test (internal wall):

Aristotle's lantern:

$\square$ Gut: full empty partila $\quad$ Gonad visible? $\square$ Yes $\square$ No

Comments:

Photograph(s) taken? $\quad \square$ Yes $\square$ No Views:

Photographer/camera:

Tissues collected for archive (whirl-pak):

$\square$ Spines $\quad \square$ Test $\quad \square$ Gut $\quad \square$ Gonad $\quad \square$ Fluid in cryovial

Comments:

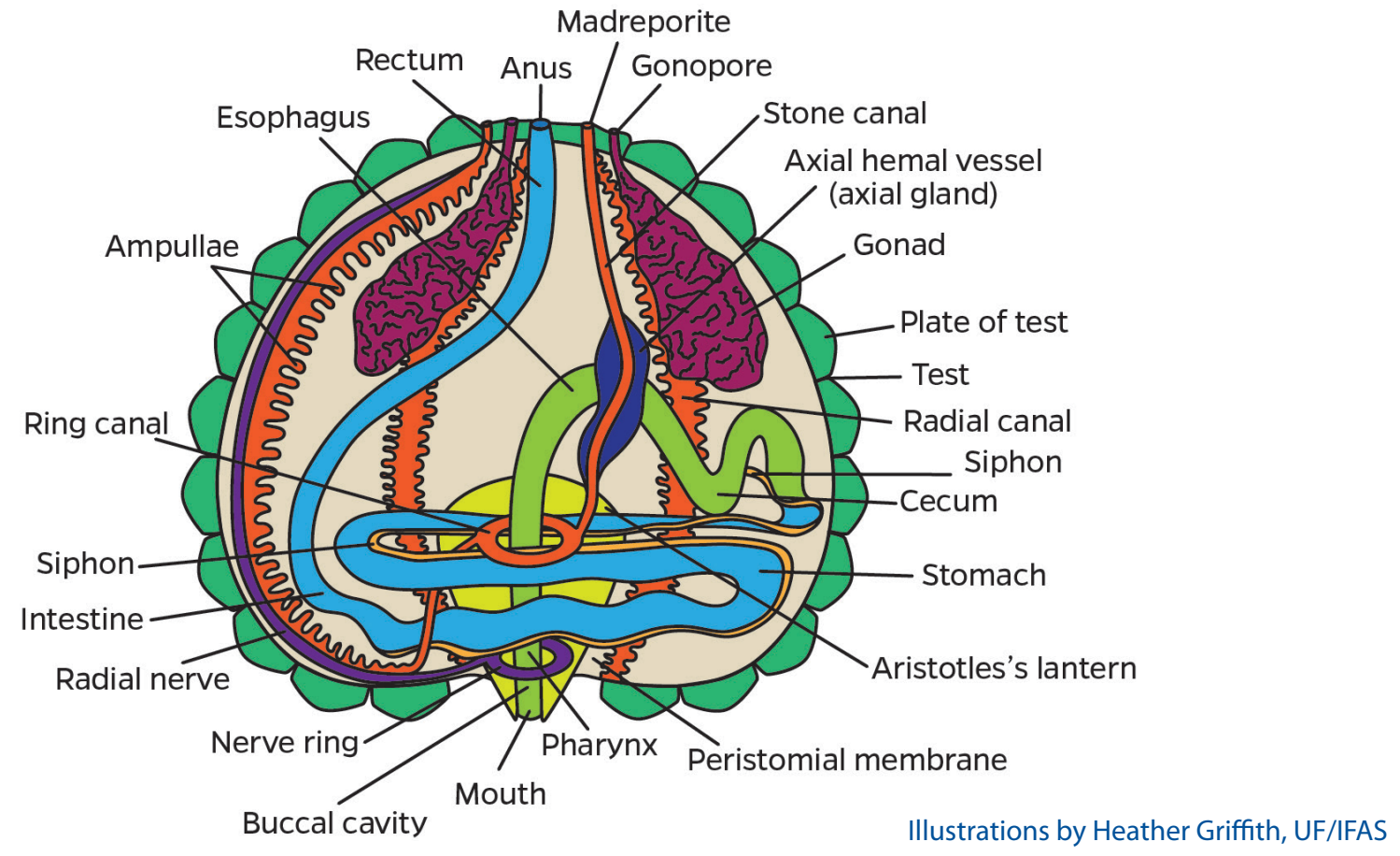


Fecal Sample Collection/Submission

Fecal samples collected: $\quad \square$ Yes

Collection time:

AM/PM Collected by:

Fecal smear preps: $\quad$ \# of slides prepared

Fecal pellet: $\quad \square$ ZincPVA $\quad \square$ Fresh $\quad \square$ Other

Submitted to:

Date:

Transport:

Histology Tissue Collection/Submission

Histology samples collected: $\quad \square$ Yes $\square$ No Collection time:

AM/PM Collected by:

Preservative: $\quad \square 9$ :1 seawater:formalin $\quad \square$ Z-fix $\quad \square$ Other

Submitted to:

Date:

Transport:

Comments:

Virology Tissue Collection/Submission

Virology samples collected: $\quad \square$ Yes $\square$ No Collection time:

AM/PM Collected by:

Tissues collected: $\quad \square$ Spine

$\square$ Test

$\square$ Gut

Gonad

$\square$ Other

Preservative: $\square$ Fresh $\quad \square-80^{\circ} \mathrm{C} \quad \square$ RNALater $\square$ Ethanol $\square$ Other

Submitted to:

Date: Transport:

Comments:

Fluid Cytology Submission

$\square$ Slides $\quad \square$ Fluid

Submitted to: Date: Transport:

Comments:

Immunology Submission

Submitted to: Date: Transport:

Comments:

Other/Comments

\section{Diadema antillarum Health Evaluation-Follow-up Lab Assessment Bacteriology}

Plated culture media: $\square$ TSA+B Incubation Temp: ___ ${ }^{\circ} \mathrm{C} \quad$ Incubation Time: __ hrs

Positive growth: $\square$ Lesion __ hrs $\quad \square$ Coelomic Fluid __ hrs $\quad \square$ Spines hrs $\square$ Other___ hrs

Identification method: $\square$ None $\quad \square$ Biolog $\quad \square$ PCR $\quad \square$ Other $\quad$ Performed by:

Identification: 


\section{Comments:}

\section{Fecal Cytology}

Fecal smear preps: \# of slides Stain(s): $\square$ Diff-Quick $\square$ Giemsa $\square$ Other

Fecal sample preservation: $\quad \square$ Zinc PVA $\square-80^{\circ} \mathrm{C}$

Amoeba: $\quad \square$ Present in fluid $\quad \square$ Present in feces $\quad \square$ Present in $\square$ Not Seen

Comments:

\section{Fluid Cytology}

Cytology performed: $\quad \square$ Yes $\quad \square$ No $\quad$ Performed by:

Fluid smear preps: \# of slides Stain(s): $\quad \square$ Diff-Quick $\quad \square$ Giemsa $\quad \square$ Other

Differential cell count:

Other:

Comments:

\section{Histology}

Decalification: $\square$ Cal-Ex II $\square$ EDTA $\square$ Other

Stains: $\square$ H\&E $\quad \square$ Other Processing: $\square$ Paraffin $\square$ Epoxy resin

Processed by: Slides read by:

Results:

Comments:

\section{Immunology}

Immunology performed: $\quad \square$ Yes $\quad \square$ No $\quad$ Performed by:

Results:

Comments:

\section{Virology}

Methodology: $\quad \square$ PCR $\quad \square$ Virus isolation $\quad$ Performed by: 
Tested for:

Results:

Comments:

Other/Comments

\section{Protocols for the Release of Black Long-Spined Sea Urchins, Diadema antillarum Release Site Selection}

Selection of an appropriate release site(s) should meet the following criteria:

1. Release site should be of suitable reef habitat and have historic presence of the species within the last three decades.

2. Release site should not be located within a direct or indirect impact area for any permitted, authorized or reasonably foreseeable marine coastal construction activity (e.g., dredging, beach nourishment, pipeline or communication cable installations), or within exclusion or buffer areas (e.g., military, aquaculture).

\section{Definitions}

For purposes of this protocol:

1. "Batch" is the total number of urchins in a group intended for release.

2. "Manual" is the "Diagnostic Methods for Health Assessment of the Long-Spined Sea Urchin, Diadema antillarum" (see online link and hard copy).

3. "Release" is the introduction or reintroduction of eggs or organisms into waters of the state (including municipal waters), that have been held, bred, or reared in ex situ environments.

4. "Urchin" or "urchins" is black long-spined sea urchins (Diadema antillarum). 


\section{Visual Health Assessment}

Each urchin must be visually evaluated prior to release to ensure that they appear in good health and are apparently free from any obvious signs of disease. All urchins should be subjected to a Category One Behavioral Assessment (see below) and a general visual examination. A subset of the batch (20\%) should be subjected to a more detailed but nonlethal examination process. This will include a Category Two Behavioral Assessment and a more detailed physical examination that includes evaluation of gross appearance and the collection of morphometric data.

\section{a. Behavioral Assessments}

Behavioral characteristics that should be evaluated are listed below. Urchins should show no visible signs of abnormal behavior, based on the following criteria:

All urchins to be released must pass both Behavioral Assessments in Category One, and 20\% of the batch should pass at least three behaviors in Category Two (see Manual for additional information):

\section{Category One}

- "Attachment to Substrate" is noted when removing the urchin from the tank or aquarium where it was held. A healthy urchin should be firmly attached to the substrate.

- "Spine Position" should be assessed while the urchin is still in the holding area, and as the initial part of the physical examination. Regardless of position orientation, a healthy urchin should have spines erect and extended. Spines that appear to be drooping may be indicative of disease.

\section{Category Two}

- "Defecation" is noted when the urchin is first handled. A healthy urchin should have a full gut, so a recentlycollected urchin would be expected to defecate when manually examined.

- "Righting Response" is defined as the urchin's ability to correct its orientation when placed upside down in a pan. A healthy urchin should make an effort to right itself when placed in an inverted position.

- "Touch and Defense Responses" are very similar and may be hard to distinguish. A "Touch Response" is defined as the urchin's response to touch. A healthy urchin should attempt to move away from the source of the touch, or it may raise its spines towards the perceived threat. A "Defense Response" is tested by "threatening" the urchin with a probe. A healthy urchin should form a thick multi-spear-like "defense" structure by pulling its spines together and pointing them in the direction of the threat.

- "Light Response" is defined as the urchin's behavioral response to light. A healthy urchin should attempt to move under shelter or shade (i.e., away from a light source).

- "Tube Feet Activity" evaluates the movement of tube feet when the urchin is handled. A healthy urchin should have active tube feet, which may increase when the urchin is handled, indicating an active escape response.

\section{b. Appearance}

All urchins should be of healthy appearance. Juvenile (or small) urchins may have horizontal striping on the spines.

Twenty percent of urchins must be subjected to a thorough physical examination. Weight and test diameter will be documented on this subset ( $20 \%$ of the batch) as part of the more detailed physical examination

To be deemed healthy, urchins should meet the following criteria:

- No more than $5 \%$ of the spines broken or missing

- No lesions on the test (external surface). Specifically they must have:

- Less than $5 \%$ of the test exposed (bare area)

- No areas of tissue loss or discoloration (in relation to the rest of the test)

- No grossly visible attached organisms

- No abnormal growths (altered morphology of tissue or test). 


\section{Hatchery Data}

The following data must be recorded prior to any release of each batch represented, and must be reported to the FWC. Hatcheries are expected to follow aquaculture standards and FDACS BMPs (http://www.freshfromflorida.com/content/ download/64045/1520653/BMP_RULE_AND_MANUAL_FINAL.pdf).

Information on the following should be provided when an SAL permit is requested:

1. Broodstock source-provide name of collector, date of collection, and collection location (GPS coordinates, water depth)

2. Source of water (e.g., protected, artificial, well)

3. Water quality and system design

4. Disease history and management

5. Number of days that batch were maintained in the hatchery

6. Release location (GPS coordinates, water depth)

\section{Disposition and Health Examination}

- If all urchins in the batch pass the health assessment protocol (Behavioral Assessments and Physical Examination as described above), they can be released.

- Urchins that do not pass the health assessment shall not be released.

- If greater than or equal to $90 \%$ of the urchins in the batch pass the health assessment, then the healthy urchins can be released. It is recommended that the urchins that fail (or a subset of) shall be subject to a follow-up health diagnostic evaluation. These urchins shall be sacrificed for archival purposes and a detailed health check, including morphometrics, gross evaluation, clinical pathology, microbiology, histology, and parasitology (including fecal smear), should be conducted, as described in the Manual.

- If $50 \%-89 \%$ of the batch passes the health assessment, then the healthy individuals can be released after they have been kept within an in-water "quarantine" phase for observation; the site should not have any endemic urchins within 10 kilometers. A 5\%-10\% subset shall be sacrificed for archival purposes and a Protocols for the Release of Black Long-Spined Sea Urchins, Diadema antillarum detailed health evaluation, including morphometrics, gross evaluation, clinical pathology, microbiology, histology, parasitology (including fecal smear), should be conducted, as described in the Manual.

- If $49 \%$ or less of the batch passes the health assessment, then none of the urchins may be released. A complete diagnostic exam is recommended of a subset as well as a follow-up consultation at the hatchery. If the intent is to

improve the health status of these urchins through improved husbandry so that they may eventually be eligible for release, then the same health assessment would need to be conducted.

At this moment in time, there are no documented pathogens that prohibit the release of urchins. However, urchins that do not pass the health requirements listed above shall not be released. It is desirable that a subset of abnormal urchins be subjected to the diagnostic protocols described in the Manual to further increase our knowledge of diseases in this species. Applicants should contact the FWC for further guidance.

\section{Data Required Prior to Release}

The following data must be recorded prior to the release of each urchin batch:

1. Documented verification that the urchins are healthy, based on the Health Assessment and Examination criteria above.

2. Batch ID number. 
3. As appropriate, molecular screening has been conducted for genetic purposes, and/or genetic data has been provided and urchins approved for release

4. Morphometrics (average size range [test diameter and weight] of urchins that were examined for the Health Assessment)

5. Photographic documentation of representative specimens in the batch immediately prior to and within an hour after release.

6. It is recommended that a comment section be provided on the data collection sheet in the event that the applicant wishes to provide any additional information they may deem to be relevant (i.e., water visibility, temperature, etc.) at the time of release. It is recommended that releases should not be conducted when there are adverse environmental or weather conditions.

\section{Monitoring Recommendations Post Release}

Follow-up monitoring of released urchins is desirable but not required, ideally after one and six months from release if possible. If feasible, urchins should be tagged (following consultation with FWC).

It is anticipated that post-release monitoring will be conducted but it is not mandatory at this time. If released urchins are later observed to be unhealthy, FWC should be notified and arrangements should be made to sample or cull the released urchins.

\section{Notification Requirement}

Notification must be made to the FWC in accordance with the license requirements if any disease is suspected.

\section{Protocol for Preparation of $10 \%$ Seawater Formalin}

\section{Materials}

- $37 \%$ formaldehyde

- Artificial seawater (Instant Ocean $/$ Reef Crystals ${ }^{\oplus}$, Blacksburg, Virginia, United States)

- Deionized water

- Measuring cylinder (1 L size)

- Magnetic stirrer

- Conical flask beaker

\section{Methods}

1. Prepare $35 \%$ artificial seawater by using Marine Mix and deionized water (or simply use natural sea water)

2. Add one part of $37 \%$ formaldehyde and 9 parts of $35 \%$ artificial seawater (or natural sea water), prepared above 


\section{Storage}

- Solution can be stored at room temperature $15^{\circ} \mathrm{C}-25^{\circ} \mathrm{C}$ for several months

Florida Fish and Wildlife Conservation Commission, Fish and Wildlife Research Institute, Fish and Wildlife Health, 3 FEB 2015, revised 28 JUN 16

\section{Protocol for Preparation of 0.5 M EDTA}

\section{Materials}

- EDTA, $\mathrm{C}_{10} \mathrm{H}_{14} \mathrm{~N}_{2} \mathrm{Na}_{2} \mathrm{O}_{8} \cdot 2 \mathrm{H}_{2} \mathrm{O}$

- $\mathrm{NaOH}$ pallet or $10 \mathrm{~N} \mathrm{NaOH}$ solution

- Deionized water

- Measuring cylinder (1 L size)

- Magnetic stirrer

- Conical flask beaker

\section{Methods}

1. $186.1 \mathrm{~g}$ ethylenediaminetetraacetic acid disodium salt dihydrate (EDTA; $\mathrm{C}_{10} \mathrm{H}_{14} \mathrm{~N}_{2} \mathrm{Na}_{2} \mathrm{O}_{8} \cdot 2 \mathrm{H}_{2} \mathrm{O} ; \mathrm{MW}=372.24 \mathrm{~g}$ ), into $800 \mathrm{~mL}$ of deionized water 
3. Add $\mathrm{NaOH}$ solution to adjust $\mathrm{pH}$ to 8 . Approximately $18-20 \mathrm{~g} \mathrm{NaOH}$ pallets necessary

4. Dilute solution to $1 \mathrm{~L}$

5. (Optional) filter through $0.5 \mu \mathrm{m}$

6. Sterilize with autoclave

\section{Storage}

- Solution can be stored at room temperature $15^{\circ} \mathrm{C}-25^{\circ} \mathrm{C}$ for several months

Florida Fish and Wildlife Conservation Commission, Fish and Wildlife Research Institute, Fish and Wildlife Health, 3 FEB 2015, revised 28 JUN 2016, 1 NOV 2018 